\title{
Advanced Geothermal Turbodrill
}

Final Report - 09/18/1998 - 03/17/2000

W. C. Maurer

May 2000

Work Performed Under Contract No. DE-FG07-98ID13680

For

U.S. Department of Energy

Assistant Secretary for

Energy Efficiency and Renewable Energy

Washington, DC

By

Maurer Engineering Inc.

Houston, TX 


\section{DISCLAIMER}

This report was prepared as an account of work sponsored by an agency of the United States Government. Neither the United States Government nor any agency Thereof, nor any of their employees, makes any warranty, express or implied, or assumes any legal liability or responsibility for the accuracy, completeness, or usefulness of any information, apparatus, product, or process disclosed, or represents that its use would not infringe privately owned rights. Reference herein to any specific commercial product, process, or service by trade name, trademark, manufacturer, or otherwise does not necessarily constitute or imply its endorsement, recommendation, or favoring by the United States Government or any agency thereof. The views and opinions of authors expressed herein do not necessarily state or reflect those of the United States Government or any agency thereof. 


\section{DISCLAIMER}

Portions of this document may be illegible in electronic image products. Images are produced from the best available original document. 
DOE/AD/13680

\section{ADVANCED GEOTHERMAL TURBODRILL \\ FINAL REPORT \\ 09/18/1998 - 03/17/2000}

\section{RECEIVED}

OCT 242000

W. C. Maurer

May 2000

Work Performed Under Contract No. DE-FG07-98ID13680

Prepared for the

U.S. Department of Energy

Assistant Secretary for

Energy Efficiency and Renewable Energy

Washington, DC

Prepared by

Maurer Engineering, Inc.

Houston, TX 


\title{
ADVANCED GEOTHERMAL TURBODRILL FINAL REPORT
}

\author{
TR00-13
}

Contract No. DE-FG07-981D13680

\author{
Prepared for: \\ U.S. DEPARTMENT OF ENERGY \\ 850 Energy Drive \\ Mail Stop 1225 \\ Idaho Falls, Idaho 83401-1563
}

Prepared by:

MAURER ENGINEERING INC. 2916 West T.C. Jester Boulevard

Houston, Texas 77018-7098

May 2000 


\section{Disclaimer}

This grant was prepared with the support of the U.S. Department of Energy (DOE) for this award DE-FG07-98ID13680. However, any opinions, findings, conclusions, or recommendations expressed herein are those of the author(s) and do not necessarily reflect the views of DOE. 


\section{Table of Contents}

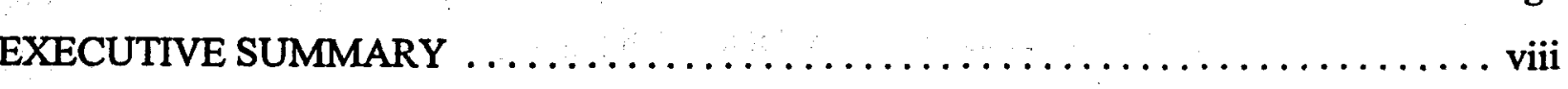

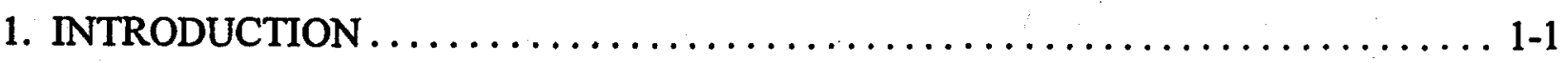

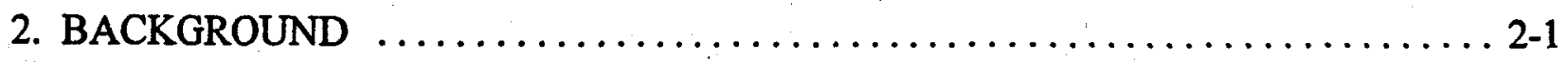

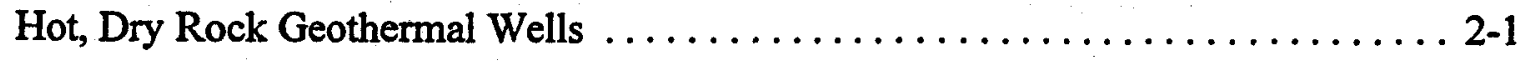

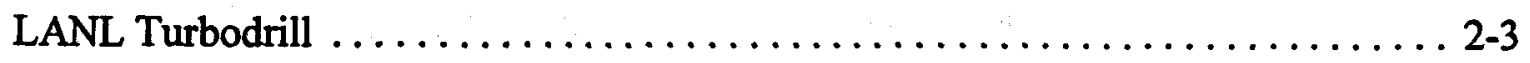

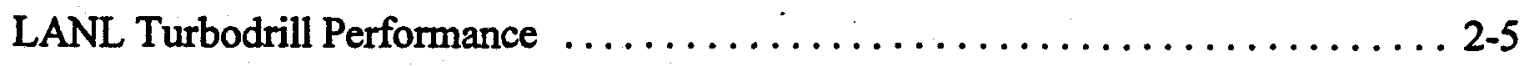

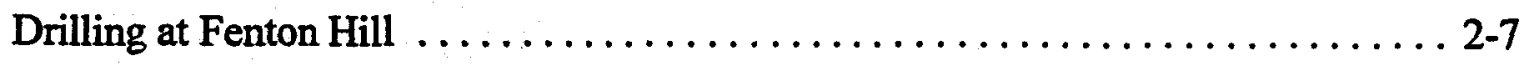

3. ADVANCED GEOTHERMAL TURBODRILL $\ldots \ldots \ldots \ldots \ldots \ldots \ldots \ldots \ldots \ldots . \ldots \ldots \ldots$

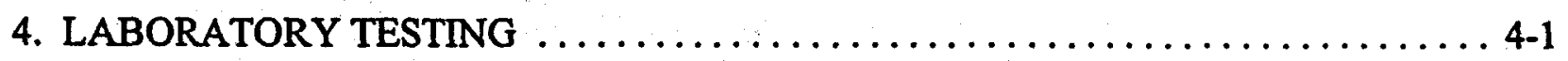

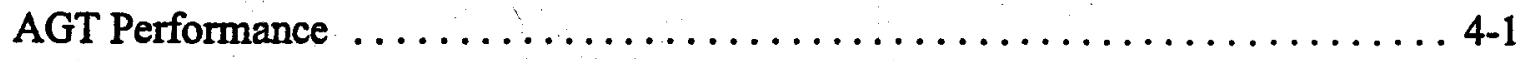

Transmission Efficiency $\ldots \ldots \ldots \ldots \ldots \ldots \ldots \ldots \ldots \ldots \ldots \ldots \ldots \ldots \ldots, 4,5$

AGT Laboratory Drilling Tests $\ldots \ldots \ldots \ldots \ldots \ldots \ldots \ldots \ldots \ldots \ldots \ldots \ldots, 4,6$

5. TURBODRILL DESIGN COMPUTER PROGRAM $\ldots \ldots \ldots \ldots \ldots \ldots \ldots \ldots \ldots$ 5-1

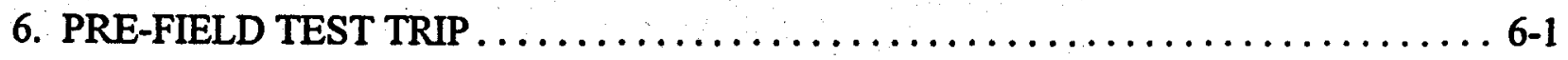

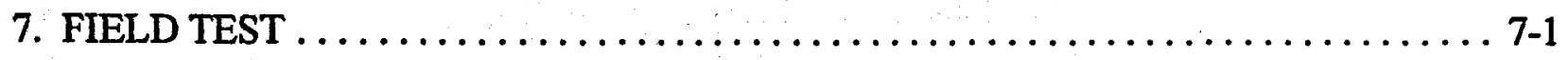

Summary $\ldots \ldots \ldots \ldots \ldots \ldots \ldots \ldots \ldots \ldots \ldots \ldots \ldots \ldots \ldots \ldots \ldots \ldots \ldots \ldots \ldots, 7-1$

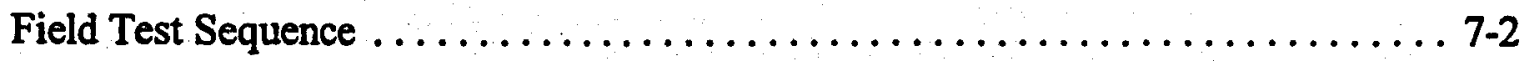

Bottom-Hole Assembly ............................... 7-3

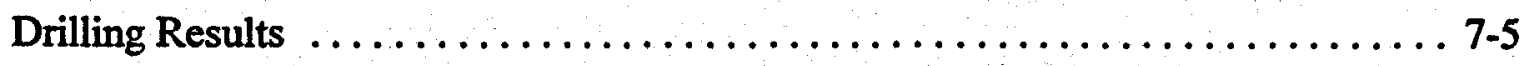

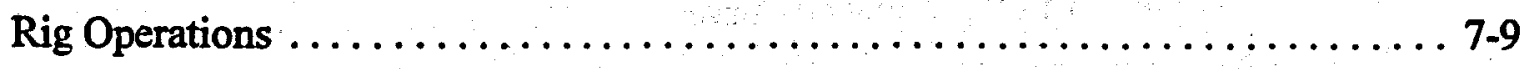

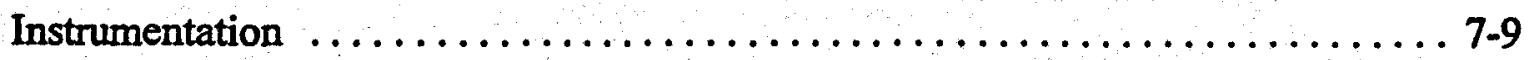

8. TURBODRILL POST-TEST INSPECTION $\ldots \ldots \ldots \ldots \ldots \ldots \ldots \ldots \ldots \ldots \ldots, 8$ 8-1

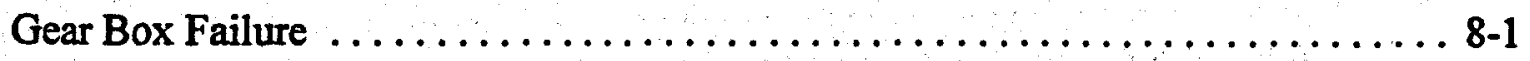

Seal Redesign $\ldots \ldots \ldots \ldots \ldots \ldots \ldots \ldots \ldots \ldots \ldots \ldots \ldots \ldots \ldots \ldots \ldots, 8,6$

Turbine Blades ................................... 8-6

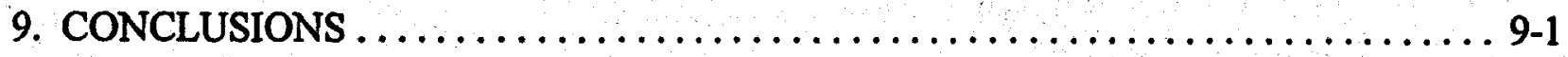

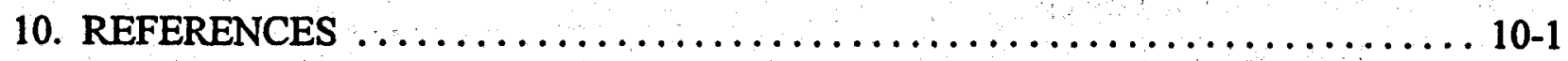

APPENDIX A

APPENDIX B 


\section{Table of Figures}

Page

Figure A-1. Greenhouse Gas Emissions (U. S. DOE Web Page) ............... viii

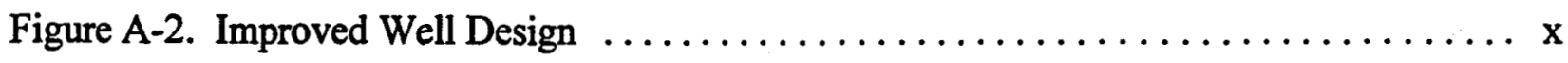

Figure A-3. LANL Geothermal Turbodrill $\ldots \ldots \ldots \ldots \ldots \ldots \ldots \ldots \ldots \ldots \ldots \ldots \ldots \ldots \ldots$

Figure A-4. Turbodrill Blades $\ldots \ldots \ldots \ldots \ldots \ldots \ldots \ldots \ldots \ldots \ldots \ldots \ldots \ldots \ldots \ldots \ldots$

Figure A-5. Advanced Geothermal Turbodrill (AGT) $\ldots \ldots \ldots \ldots \ldots \ldots \ldots \ldots \ldots$ xii

Figure A-6. Planetary Speed Reducer $\ldots \ldots \ldots \ldots \ldots \ldots \ldots \ldots \ldots \ldots \ldots \ldots \ldots \ldots \ldots \ldots \ldots \ldots \ldots \ldots$

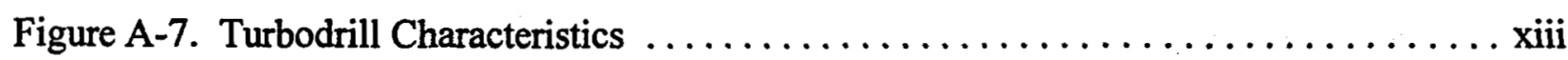

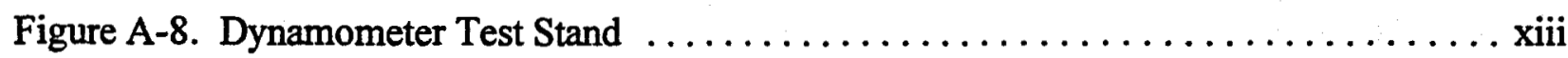

Figure A-9. AGT Performance Curves $\ldots \ldots \ldots \ldots \ldots \ldots \ldots \ldots \ldots \ldots \ldots \ldots \ldots \ldots \ldots \ldots \ldots \ldots$

Figure A-10. Laboratory Drilling Test $\ldots \ldots \ldots \ldots \ldots \ldots \ldots \ldots \ldots \ldots \ldots \ldots \ldots \ldots \ldots \ldots \ldots \ldots \ldots \ldots \ldots$

Figure A-11. PEMEX Well ARCOS511 $\ldots \ldots \ldots \ldots \ldots \ldots \ldots \ldots \ldots \ldots \ldots \ldots \ldots \ldots$

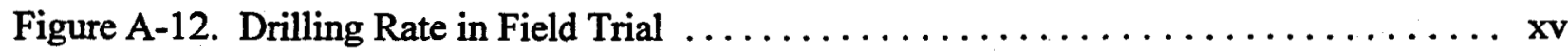

Figure 2-1. LANL Hot, Dry Rock Geothermal Wells ................... 2-1

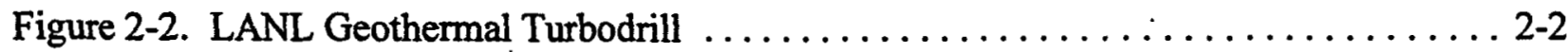

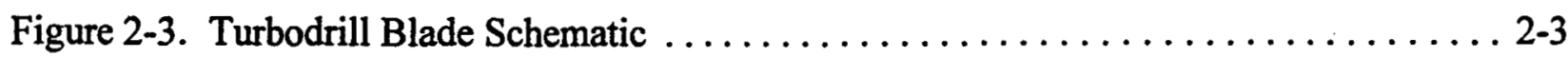

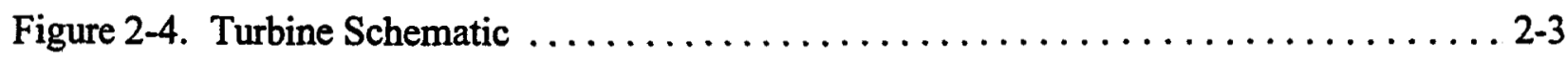

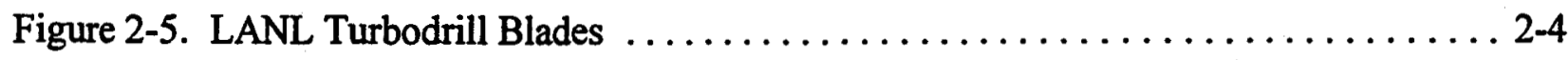

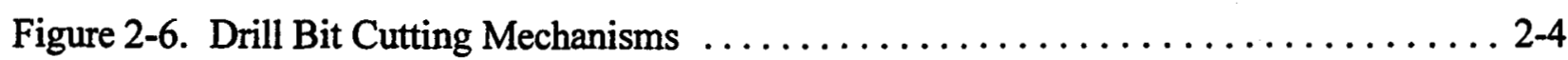

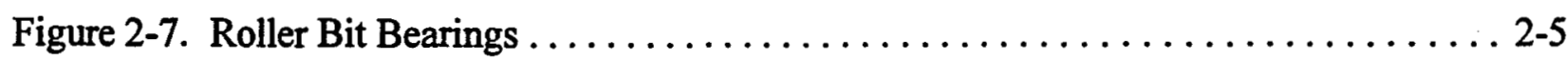

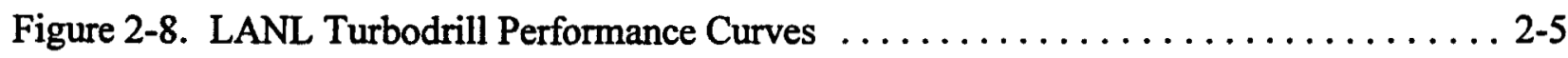

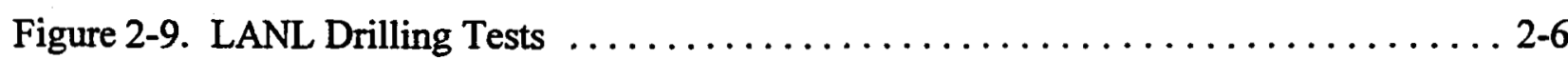

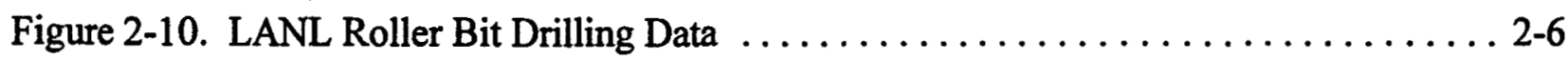

Figure 2-11. Roller Bit Tests ................................. 2-7

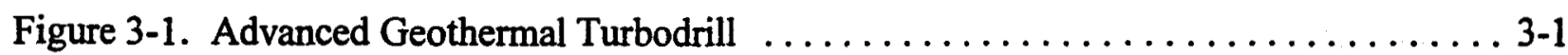

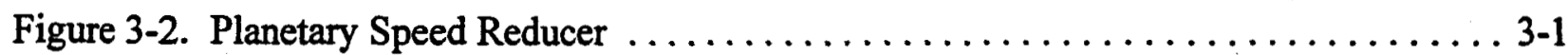

Figure 3-3. Vector Two-Stage Speed Reducer $\ldots \ldots \ldots \ldots \ldots \ldots \ldots \ldots \ldots \ldots \ldots \ldots \ldots \ldots \ldots \ldots .2$

Figure 3-4. Sun and Planetary Gears $\ldots \ldots \ldots \ldots \ldots \ldots \ldots \ldots \ldots \ldots \ldots \ldots \ldots \ldots \ldots \ldots \ldots, 2$

Figure 3-5. Turbodrill with Adjustable Bent Housing $\ldots \ldots \ldots \ldots \ldots \ldots \ldots \ldots \ldots . . \ldots \ldots$

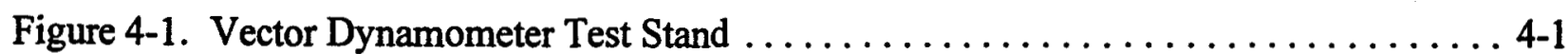

Figure 4-2. AGT Performance with Speed Reducer $\ldots \ldots \ldots \ldots \ldots \ldots \ldots \ldots \ldots \ldots, 4-2$ 


\section{Table of Figures (Cont'd.)}

Figure 4-3. AGT Performance without Speed Reducer (LANL Turbodrill) ............4-2

Figure 4-3. AGT Performance without Speed Reducer (LANL Turbodrill) . . . . . . . . 4-2

Figure 4-4. Blade Entrance and Exit Angles . . . . . . . . . . . . . . . . . 4-3

Figure 4-5. Modified AGT Blade and LANL Blade $\ldots \ldots \ldots \ldots \ldots \ldots \ldots \ldots \ldots$

Figure 4-6. Efficiency of LANL and Modified AGT Blades . . . . . . . . . . 4-4

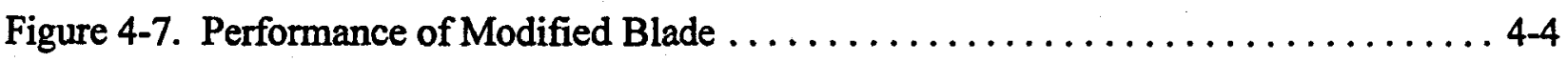

Figure 4-8. Comparison of LANL to AGT Turbodrill $\ldots \ldots \ldots \ldots \ldots \ldots \ldots \ldots \ldots \ldots$

Figure 4-9. Comparison of Turbodrill with and without Speed Reducer . . . . . . . . 4-6

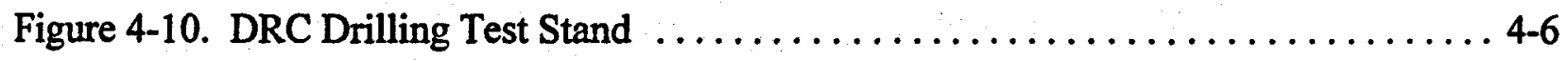

Figure 4-11. Steel Test Box $\ldots \ldots \ldots \ldots \ldots \ldots \ldots \ldots \ldots \ldots \ldots \ldots \ldots \ldots \ldots \ldots \ldots$

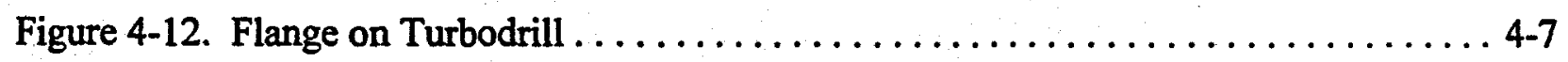

Figure 4-13. Mud Pumps $\ldots \ldots \ldots \ldots \ldots \ldots \ldots \ldots \ldots \ldots \ldots \ldots \ldots \ldots \ldots \ldots$

Figure 4-14. 121/4-inch Hole in Texas Pink Granite . . . . . . . . . . . . . . 4-9

Figure 4-15. AGT Laboratory Drilling Rate inTexas Pink Granite . . . . . . . . . . . . 4-9

Figure 4-16. 121/4-inch Carbide Roller Bit in Texas Pink Granite . . . . . . . . . . . . . . 4-9

Figure 5-1. TURBO Input Screen $\ldots \ldots \ldots \ldots \ldots \ldots \ldots \ldots \ldots \ldots \ldots \ldots \ldots \ldots \ldots \ldots \ldots \ldots \ldots \ldots$

Figure 5-2. TURBO Program Output Screen $\ldots \ldots \ldots \ldots \ldots \ldots \ldots \ldots \ldots \ldots \ldots \ldots$

Figure 5-3. Tabular Output of TURBO $\ldots \ldots \ldots \ldots \ldots \ldots \ldots \ldots \ldots \ldots \ldots \ldots$

Figure $5-4$. Graphical Output of TURBO $\ldots \ldots \ldots \ldots \ldots \ldots \ldots \ldots \ldots \ldots \ldots \ldots \ldots$

Figure 6-1. PEMEX Rig $4002 \ldots \ldots \ldots \ldots \ldots \ldots \ldots \ldots \ldots \ldots \ldots \ldots \ldots \ldots \ldots \ldots \ldots \ldots \ldots \ldots$

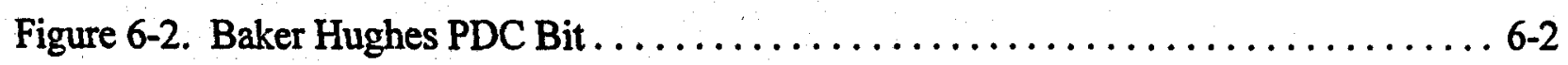

Figure 6-3. Bit Specification Sheet $\ldots \ldots \ldots \ldots \ldots \ldots \ldots \ldots \ldots \ldots \ldots \ldots \ldots \ldots \ldots$

Figure 6-4. Gardner Denver PZ-8 Pump . . . . . . . . . . . . . . . . . $6-4$

Figure $7-1$. Location of PEMEX Wells $\ldots \ldots \ldots \ldots \ldots \ldots \ldots \ldots \ldots \ldots \ldots \ldots \ldots$

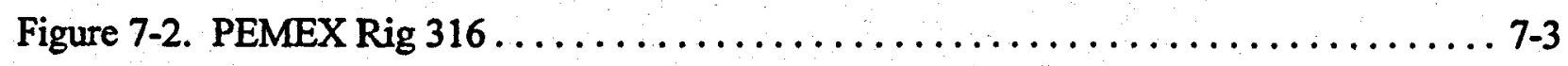

Figure 7-3. Bottom-Hole Assembly $\ldots \ldots \ldots \ldots \ldots \ldots \ldots \ldots \ldots \ldots \ldots \ldots \ldots \ldots$

Figure 7-4. AGT Before Entering Well $\ldots \ldots \ldots \ldots \ldots \ldots \ldots \ldots \ldots \ldots \ldots \ldots \ldots$

Figure 7-5. ARCOS 511 Penetration Rate $\ldots \ldots \ldots \ldots \ldots \ldots \ldots \ldots \ldots \ldots \ldots$

Figure 7-6. Advanced Geothermal Turbodrill ROP $\ldots \ldots \ldots \ldots \ldots \ldots \ldots \ldots \ldots \ldots \ldots$

Figure 7-7. Stand Pipe Pressure $\ldots \ldots \ldots \ldots \ldots \ldots \ldots \ldots \ldots \ldots \ldots \ldots \ldots \ldots \ldots \ldots$

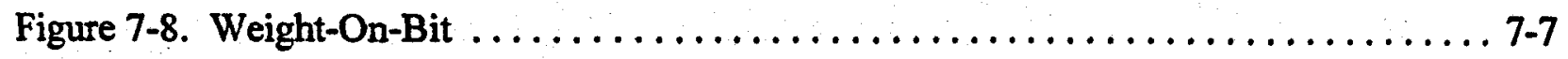




\section{Table of Figures (Cont'd.)}

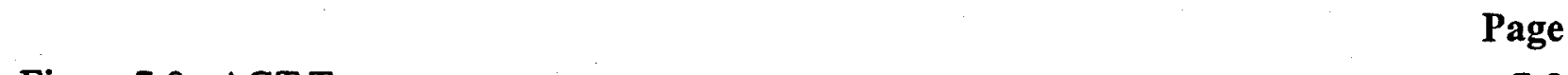

Figure 7-9. AGT Torque $\ldots \ldots \ldots \ldots \ldots \ldots \ldots \ldots \ldots \ldots \ldots \ldots \ldots \ldots \ldots \ldots$

Figure 7-10. AGT Flow Rate $\ldots \ldots \ldots \ldots \ldots \ldots \ldots \ldots \ldots \ldots \ldots \ldots \ldots \ldots \ldots$

Figure 7-11. Large Drill Cuttings $\ldots \ldots \ldots \ldots \ldots \ldots \ldots \ldots \ldots \ldots \ldots \ldots \ldots \ldots$

Figure 7-12. Halliburton Turbine Flow Meter $\ldots \ldots \ldots \ldots \ldots \ldots \ldots \ldots \ldots \ldots \ldots$. $\ldots \ldots$

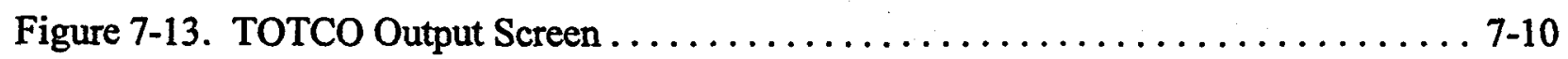

Figure 8-1. Planetary Gear after Disassembly ..................... 8-1

Figure 8-2. Planetary Gear with Drill Fines $\ldots \ldots \ldots \ldots \ldots \ldots \ldots \ldots \ldots \ldots \ldots \ldots .2$

Figure 8-3. Upper Gear Reducer Seal . . . . . . . . . . . . . . . . . . 8-2

Figure 8-4. Aluminum/Bronze Thrust Washer $\ldots \ldots \ldots \ldots \ldots \ldots \ldots \ldots \ldots \ldots \ldots$

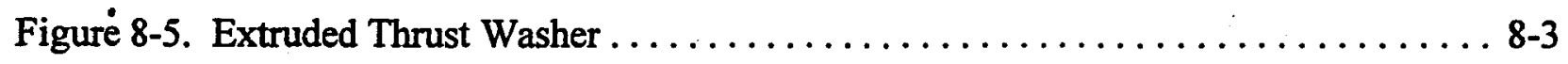

Figure 8-6. Good Face Seal $\ldots \ldots \ldots \ldots \ldots \ldots \ldots \ldots \ldots \ldots \ldots \ldots \ldots \ldots \ldots$

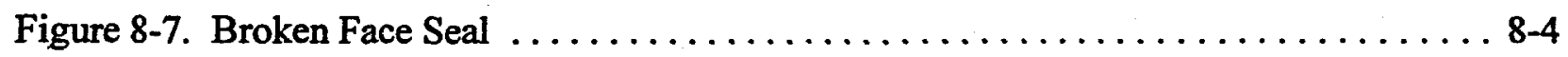

Figure 8-8. Heat Checking on Face Seal . . . . . . . . . . . . . . . . . . 8 -4

Figure 8-9. Gear Box Upper Stage . . . . . . . . . . . . . . . . . . . 8-5

Figure 8-10. Seized Thrust Bearing $\ldots \ldots \ldots \ldots \ldots \ldots \ldots \ldots \ldots \ldots \ldots \ldots \ldots$

Figure 8-11. New Roller Thrust Bearing $\ldots \ldots \ldots \ldots \ldots \ldots \ldots \ldots \ldots \ldots \ldots$

Figure 8-12. Worn Stator $\ldots \ldots \ldots \ldots \ldots \ldots \ldots \ldots \ldots \ldots \ldots \ldots \ldots \ldots$

Figure 8-13. Worm Stator $\ldots \ldots \ldots \ldots \ldots \ldots \ldots \ldots \ldots \ldots \ldots \ldots \ldots \ldots \ldots$

Figure 8-14. Hole in Stator Ring $\ldots \ldots \ldots \ldots \ldots \ldots \ldots \ldots \ldots \ldots \ldots \ldots \ldots \ldots$ 


\section{Table of Tables}

TABLE A-1. U.S. Energy Consumption (U.S. DOE, EREN) $\ldots \ldots \ldots \ldots \ldots \ldots \ldots \ldots \ldots$ ix

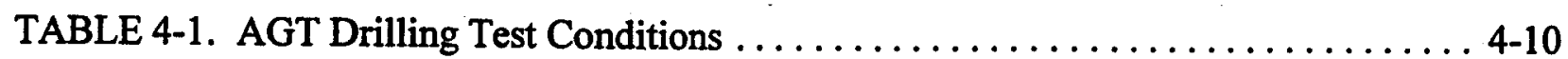

TABLE 5-1. Comparison of TURBO Predictions with Measured Data . . . . . . . . . 5-4

TABLE 7-1. Field Test Schedule $\ldots \ldots \ldots \ldots \ldots \ldots \ldots \ldots \ldots \ldots \ldots \ldots \ldots \ldots \ldots \ldots$

TABLE 7-2. Bottom-Hole Assembly $\ldots \ldots \ldots \ldots \ldots \ldots \ldots \ldots \ldots \ldots \ldots \ldots \ldots$ 


\section{ADVANCED GEOTHERMAL TURBODRILL FINAL REPORT}

\section{Executive Summary}

Concerns about global climate change are expected to drive reductions in greenhouse gas emissions associated with the production and use of fossil energy. Scientists cite such phenomena as the melting of polar ice caps and increases in weather volatility as evidence that climate change is already underway, and a general consensus is growing among both political and industry leaders that actions must be taken to reduce greenhouse gas emissions to prevent far-reaching consequences. (U.S. DOE, 1999).

One means of producing electricity without generating greenhouse gases is to increase use of geothermal energy sources (Figure A-1) which currently account for only a fraction of the Nation's total energy (Table A-1). A major barrier to geothermal energy development is its high cost (as compared to fossil fuels). For geothermal energy to be more competitive and widely exploited, these costs must be substantially reduced.

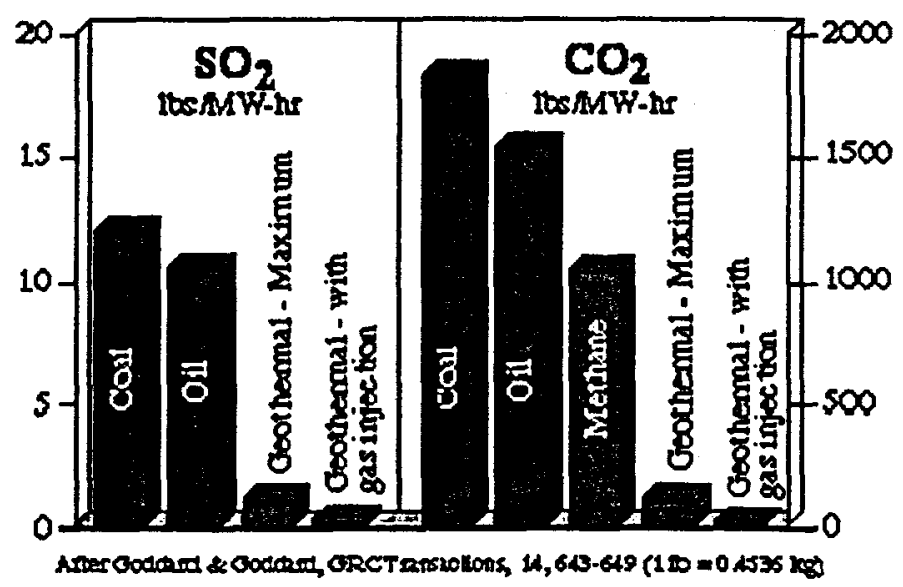

Figure A-1. Greenhouse Gas Emissions

(U. S. DOE Web Page) 
Table A-1. U.S. Energy Consumption (U.S. DOE, EREN)

\begin{tabular}{|c|c|c|c|c|}
\hline \multicolumn{5}{|c|}{ U.S. Energy Consumption and Electricity Generation. 1997} \\
\hline & \multicolumn{2}{|c|}{ Consumption } & \multicolumn{2}{|c|}{ Electricity Generation } \\
\hline & (Quads*) & (\%Total) & $($ Bill.kWh**) & (\%Total) \\
\hline Total & 94 & & 3,532 & \\
\hline Coal/Coal Coke & 21 & 23 & 1,853 & 52 \\
\hline Petroleum & 36 & 39 & 96 & 3 \\
\hline Natural Gas & 23. & 24 & 512 & 14 \\
\hline Nuclear & 7 & 7 & 629 & 18 \\
\hline Renewables & 7 & 8 & 443 & 13 \\
\hline Hydro & 4 & 4.2 & 360 & 11 \\
\hline Biomass/Biofuel & 3 & 2.9 & 62 & 2 \\
\hline Geothermal & 0.32 & 0.34 & 16 & 0.46 \\
\hline Solar & 0.07 & 0.08 & 1 & 0.03 \\
\hline Wind & 0.04 & 0.04 & 4. & 0.11 \\
\hline \multicolumn{5}{|c|}{$\begin{array}{l}\text { *A quad is } 1 \text { quadrillion British Thermal Units (BTU), and is the equivalent of about } 180 \\
\text { million barrels of crude oil. } \\
\text { ** Bill.kWh }=\text { billion kilowatt-hours }(\mathrm{kWh}) .1 \mathrm{kWh} \text { is the equivalent of running a } 100 \text { Watt light } \\
\text { bulb for } 10 \text { hours. }\end{array}$} \\
\hline
\end{tabular}

Approximately $50 \%$ of the cost of a new geothermal power plant is in the wells that must be drilled and completed to provide the geothermal fluids that will be used to generate electricity. Compared to the majority of oil and gas wells, geothermal wells are more difficult and costly to drill for several reasons. First, most U.S. geothermal resources consist of hot, hard crystalline rock formations which drill much slower than the relatively soft sedimentary formations associated with most oil and gas production. Second, high downhole temperatures found in these wells can greatly shorten equipment life or preclude the use of some technologies altogether. Third, producing viable levels of electricity from geothermal fields requires the use of large diameter bores and a high degree of fluid communication, both of which increase drilling and completion costs. Optimizing fluid communication often requires creation of a directional well to intersect the best and largest number of fractures capable of producing hot geothermal fluids. Current drilling practices rely on rotating drill pipe with a rotary table to drill the high temperature portions of the well, because mud motors, typically used to control well direction, fail at geothermal temperatures. 
Moineau motor stators made with elastomers cannot operate at geothermal temperatures, so they are limited to the upper portion of the hole, which limits the design and production capabilities of the wells. To overcome these limitations, Maurer Engineering Inc. (MEI) has developed a turbodrill that does not use elastomers and therefore can operate at geothermal temperatures. This system allows drillers to control the well path, even in the hottest sections of the well (Figure A-2). This new turbodrill uses a special gear assembly to reduce the output speed, thus allowing a larger range of bit types, especially tri-cone roller bits, which are the bits of choice for drilling hard crystalline formations.
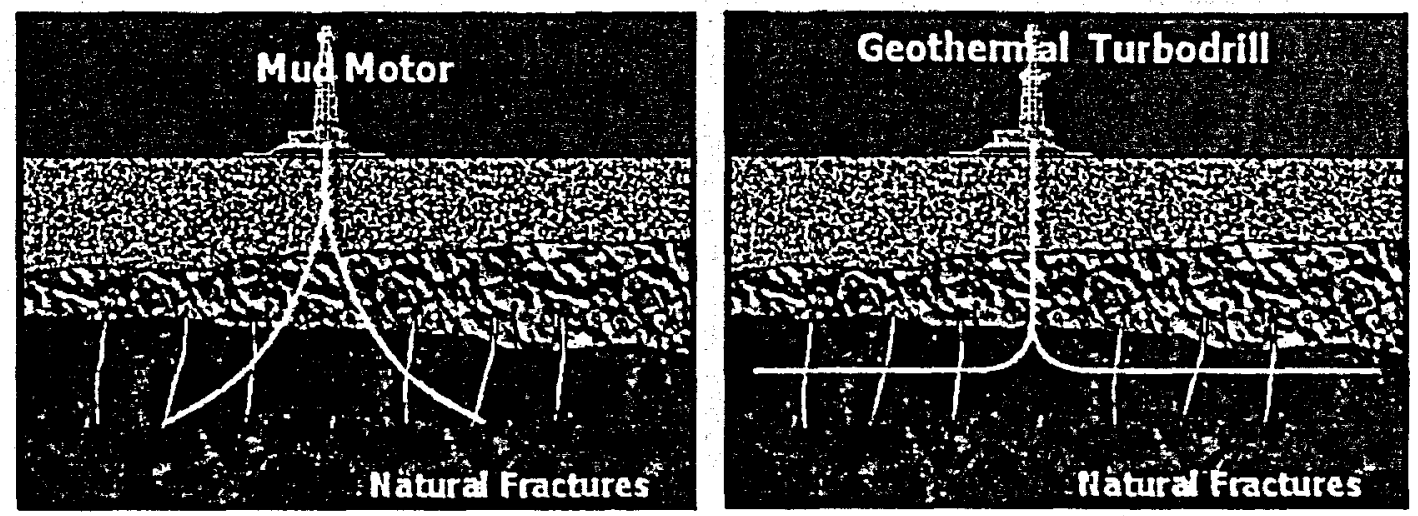

Figure A-2. Improved Well Design

The Advanced Geothermal Turbodrill (AGT) is an improvement on a turbodrill MEI previously developed for Los Alamos National Laboratories for drilling hot, dry rock geothermal wells at Fenton Hill, New Mexico (Figure A-3). Turbodrills use sets of blades (one rotor and stator per set) to convert hydraulic energy from the mud system into rotary motion of the drill bit (Figure A-4). Unlike conventional mud motors, the geothermal turbodrill is made without rubber components so it can operate at high temperatures. 


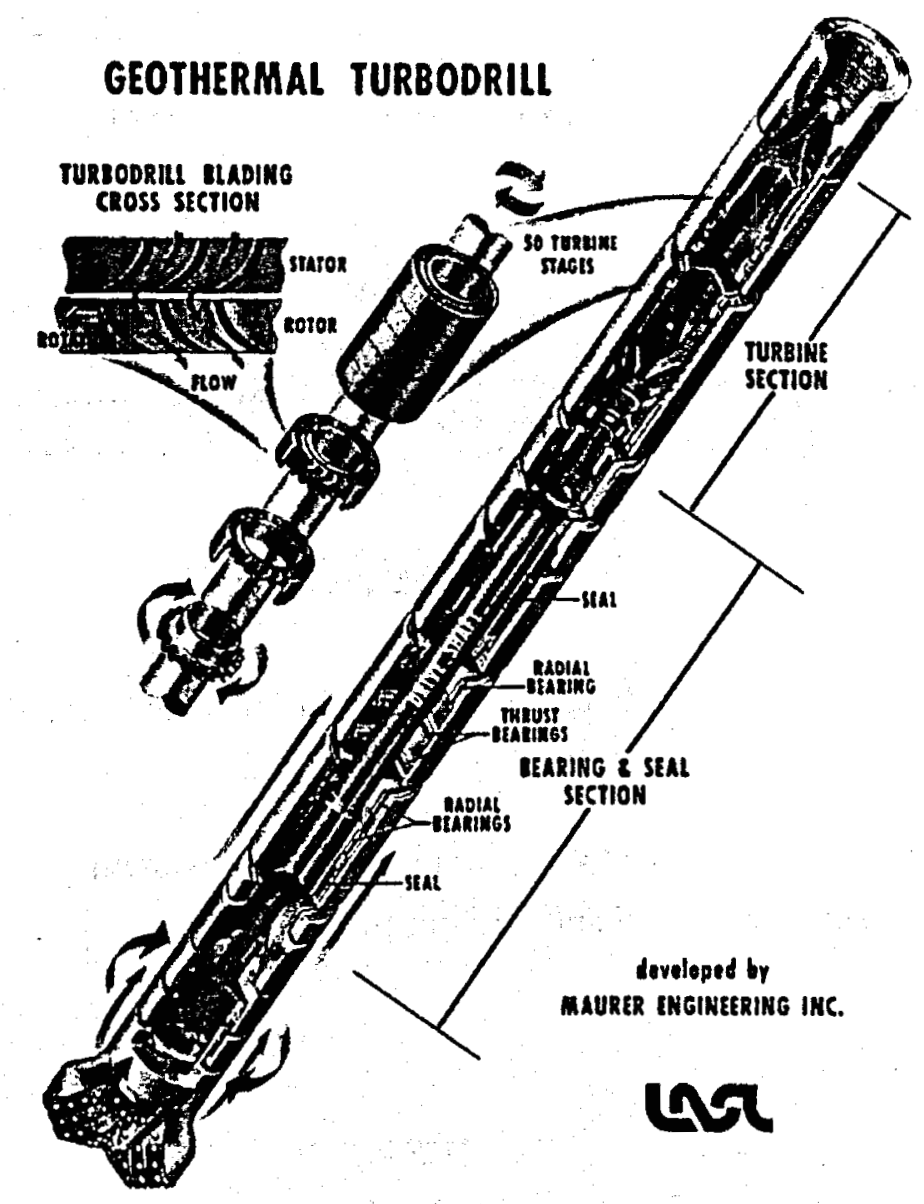

Figure A-3. LANL Geothermal Turbodrill

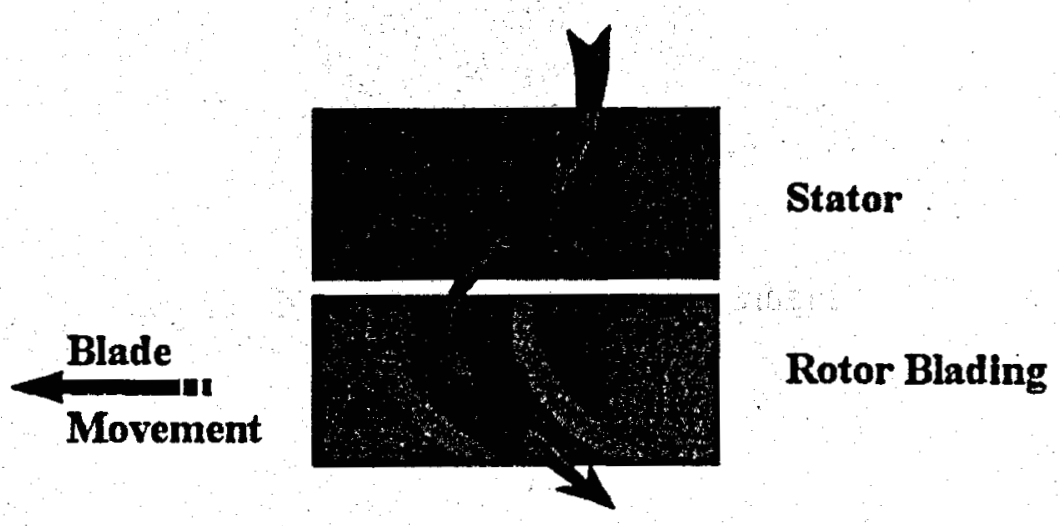

Figure A-4. Turbodrill Blades 
A Vector Oil Tool gear reducer and bearing pack was added to reduce the speed and increase the torque output of the LANL turbodrill by a factor of 13.6:1. Figure A-5 shows a schematic of the AGT.

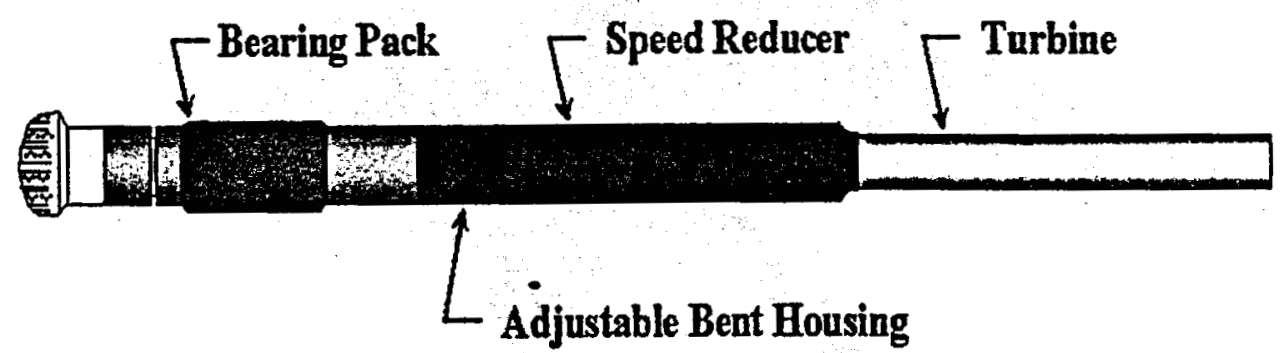

Figure A-5. Advanced Geothermal Turbodrill (AGT)

The Vector speed reducer uses a two-stage planetary gear system (Figure A-6). Figure A-7 compares turbodrill characteristics with and without the gear reducer.

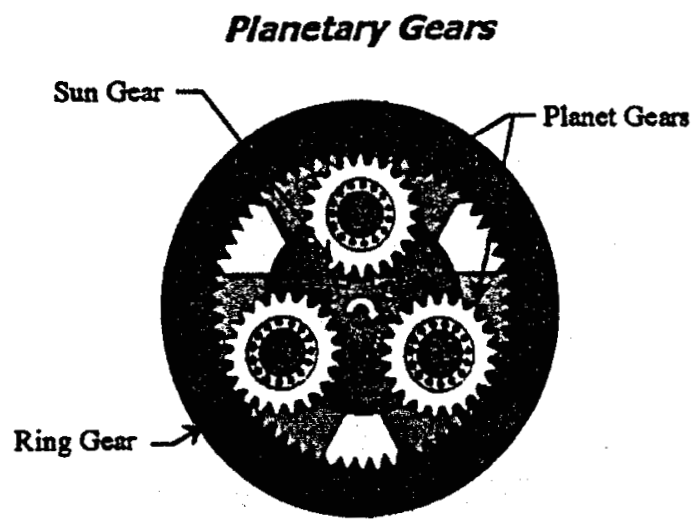

Figure A-6. Planetary Speed Reducer 


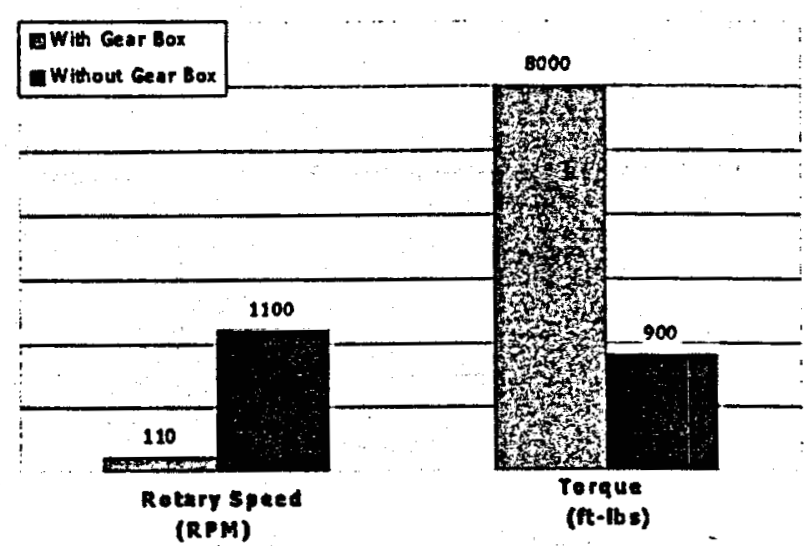

Figure A-7. Turbodrill Characteristics

Dynamometer testing was used to measure the performance of the AGT and to make improvements in the design of turbodrill components (Figure A-8). Figure A-9 shows performance curves of the AGT at the conclusion of laboratory testing. With $\mathbf{3 0}$ sets of blades, the turbodrill produced $185 \mathrm{HP}$ at $115 \mathrm{mpm}$. At peak horsepower, the AGT produces $8,500 \mathrm{ft}$-lbs of torque-a very high value for a turbodrill. This high torque allows the turbodrill to rotate roller bits at high bit weights, making the AGT ideal for geothermal drilling.

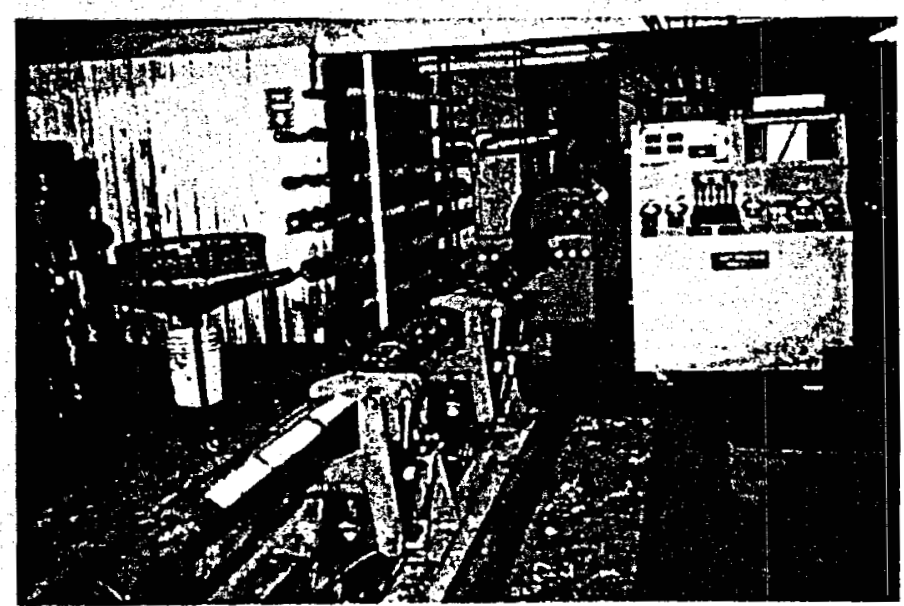

Figure A-8. Dynamometer Test Stand 


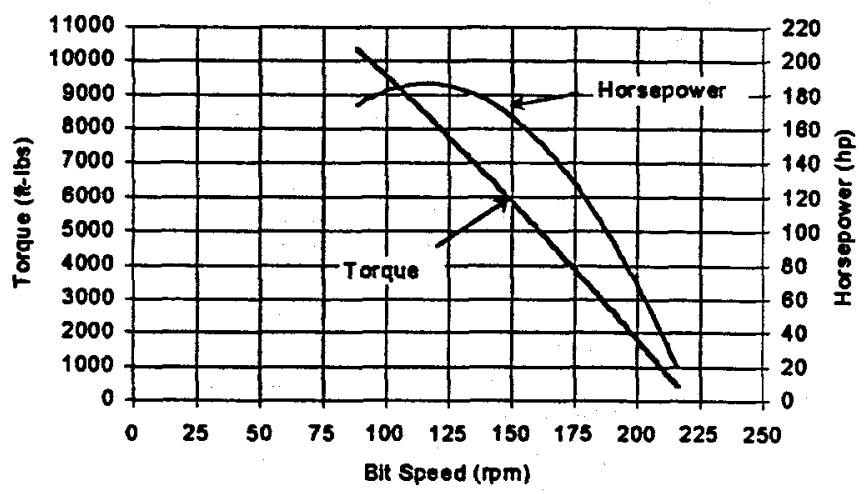

Figure A-9. AGT Performance Curves

During laboratory drilling tests (Figure A-10), the AGT drilled over $90 \mathrm{ft} / \mathrm{hr}(70,000 \mathrm{lbs}$ bit weight) in Texas Pink Granite, a 20,000-psi compressive strength crystalline rock.

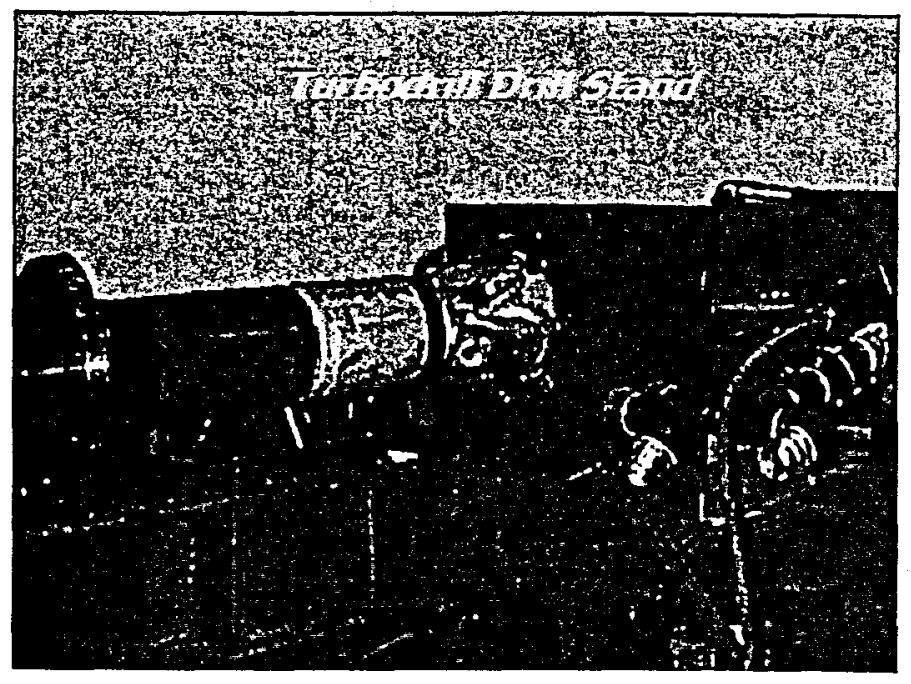

Figure A-10. Laboratory Drilling Test

Following the laboratory tests, the turbodrill was field tested in a PEMEX gas well on the United States and Mexico border near McAllen, Texas (Figure A-11). 


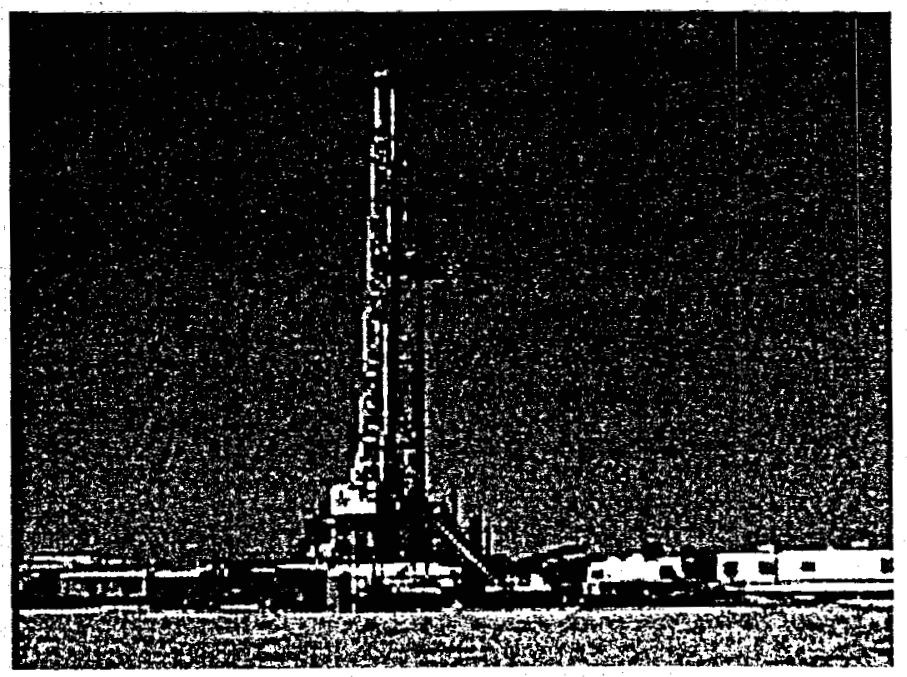

Figure A-11. PEMEX Well ARCOS511

The AGT drilled at rates of 111 to $207 \mathrm{ft} / \mathrm{hr}$ compared to $76 \mathrm{ft} / \mathrm{hr}$ with rotary drilling in an offset well using the same type bit, a 46 to $172 \%$ improvement (Figure A-12).

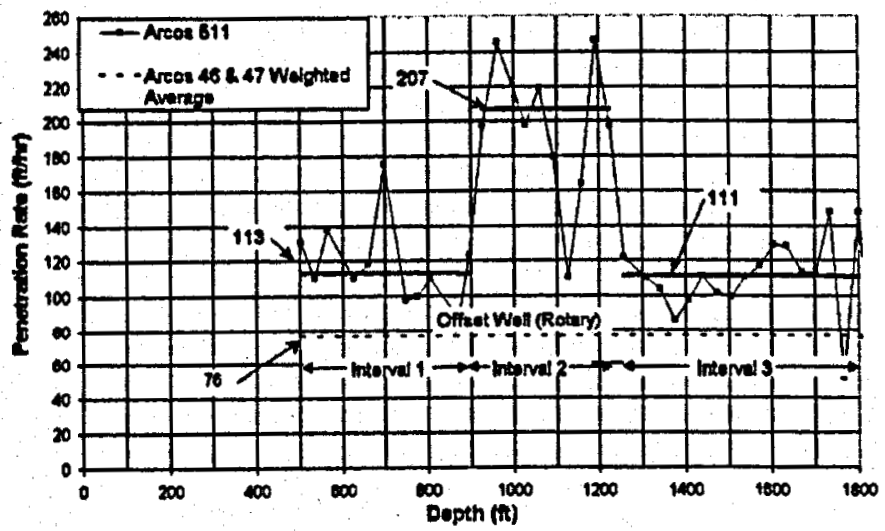

Figure A-12. Drilling Rate in Field Trial

The AGT has proven that it can operate in hard rock drilling environments and increase drilling rates over conventional drilling. The next step is to use the AGT in an actual geothermal well. CFE, Mexico's geothermal agency, has indicated its interest in the AGT by offering to provide a geothermal well for testing. Funds to provide the AGT, personnel, and logistics are now needed 
to complete the testing of this tool. Testing would be conducted in three phases. The first test would involve drilling straight or at a low angle to verify the performance of the AGT at elevated temperatures. The second test would include drilling in a geothermal well at a high angle to help intersect more fractures. In the third phase, a horizontal well would be drilled using the AGT. A horizontal well could intersect many more producing fractures and has the potential of increasing individual well production five fold-similar to the way horizontal wells have increased production in the oil field.

The AGT represents a significant improvement for drilling geothermal wells and has the potential to significantly reduce drilling costs while increasing production, thereby making geothermal energy less expensive and better able to compete with fossil fuels. The final field test of the AGT will prepare the tool for successful commercialization. 


\section{Introduction}

A strong world economy is based in large part on a reliable supply of inexpensive fossil fuels. However, these fuels, which include oil, coal, and natural gas, have recently been identified as possible causes for global climate change. The products produced when these fuels are burned (greenhouse gases) keep heat trapped in the Earth's atmosphere and contribute to global warming. If the more dire hypotheses are true, the resulting changes could be catastrophic for mankind.

This unsettling forecast has brought renewed interest in energy forms that do not produce greenhouse gases, such as geothermal power. Additionally, even if global warming does not result from burning fossil fuels, it is only prudent for the nations of the world to exploit all forms of available energy in an intelligent fashion. There is little argument that fossil fuels are a finite resource and their use should be extended over the greatest time possible.

To accomplish this goal, the cost of alternate forms of energy must be reduced so that they can compete with oil and gas. Geothermal energy is one of the most promising non-petroleum, low polluting sources of power. It is currently used to generate heat and electricity in a number of nations, including the United States. It has proven itself to be clean and readily exploitable. However, the overall contribution of geothermal energy remains low due to its high development costs.

As much as $50 \%$ of the cost of constructing a geothermal power plant is typically in drilling and completing the wells used to recover the energy. In addition, these costs are "up-front costs" making them even more important since they cannot be recovered until the plant begins to sell power. Therefore, reducing drilling costs would have a great impact on the cost of geothermal energy. The United States Department of Energy (DOE) has sponsored a number of research projects aimed at reducing geothermal drilling costs. The geothermal department at Sandia National Laboratories has as its mission statement the goal of reducing well costs by $50 \%$ through evolutionary and revolutionary developments.

This report documents work on the development of an advanced geothermal turbodrill (AGT) that will help meet these goals. The project's objective is to develop an AGT that will reduce the cost of drilling by $50 \%$. This work seeks to build on the successful high-temperature turbodrills used to drill wells at Los Alamos National Laboratory's hot, dry rock project. The new AGT will use new 
technologies to make the turbodrill easier to control and operate, and improve its performance characteristics so that modern roller and PDC bits can be run in hard rock. To accomplish this, a speed reducer was added to the LANL turbodrill to reduce its operating speed (to the range of 80 to $150 \mathrm{rpm}$ ) and significantly increase its output torque.

This is an opportune time for developing a high-temperature directional drilling motor. In the past, the electronic instruments used to control and monitor the direction of the wellbore failed at high temperatures, limiting the practicality of directional drilling in geothermal wells. Recent developments by Sandia and others have resulted in downhole electronic packages that can operate at elevated temperatures. These improvements have been made by using new high-temperature ceramic-substrate components, and by placing the electronic packages in Dewar flasks that protect them from heat.

Conventional rubber stator PDM motors cannot operate at these high temperatures, so a new motor is needed for use with the high-temperature guidance electronic packages to allow drilling directional geothermal wells to intersect more fractures and thereby significantly increase production from these wells. 


\section{Background}

\section{Hot, Dry Rock Geothermal Wells}

In the late 1970's, the Los Alamos National Laboratory (LANL) began a project to study the feasibility of expanding geothermal energy recovery to nontraditional areas. In conventional geothermal reservoirs, naturally occurring hot water is produced. Unfortunately, these types of reservoirs are limited to only a few areas of the world. There are, however, many areas with geothermal energy sources that heat formations to high temperatures, but water is not present. Energy exploitation in these environments requires injecting water from the surface down one well and withdrawing the hot water/steam from another well which can then be passed through a generator to produce electricity. This led to LANL's Hot Dry Rock geothermal energy project.

The Hot Dry Rock concept is to drill two parallel inclined wells ( $35^{\circ}$ inclination), hydraulically fracture between these wells, and then circulate cold water down one well, through the fractures and produce hot water out of the second well (Figure 2-1).

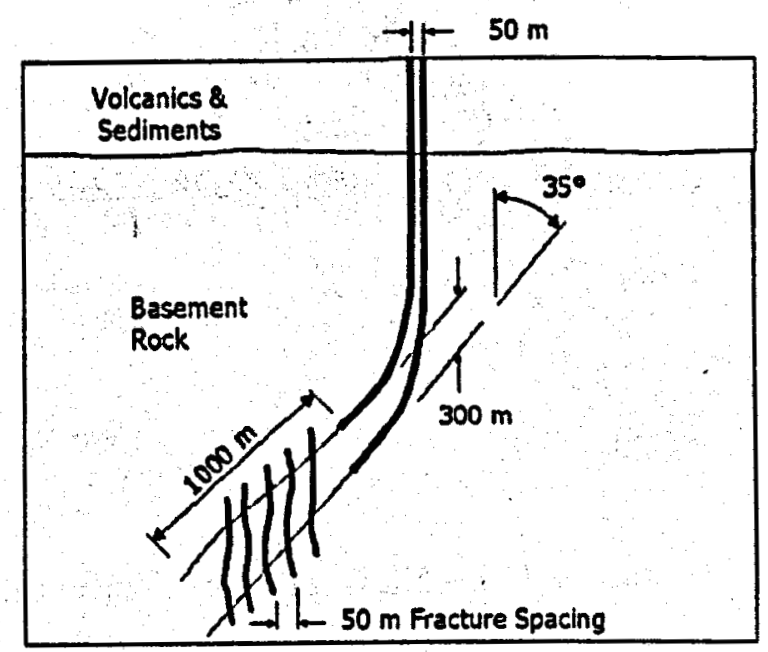

Figure 2-1. LANL Hot, Dry Rock Geothermal Wells

Inclined wells are used to increase the length of the well in the hot section of the hole to maximize production and minimize formation cooling. A directional drilling assembly consisting of a motor and bit were needed to drill the long inclined sections of the LANL wells. However, no 
motors existed at that time that were capable of drilling at geothermal temperatures, so LANL contracted Maurer Engineering Inc. (MEI) to develop a directional drilling motor for this application.

MEI developed special high-temperature geothermal turbodrills (Figure 2-2) for LANL to overcome motor temperature limitations. These turbodrills were used to drill the directional portions of LANL's Hot Dry Rock Geothermal Wells at Fenton Hill, New Mexico.

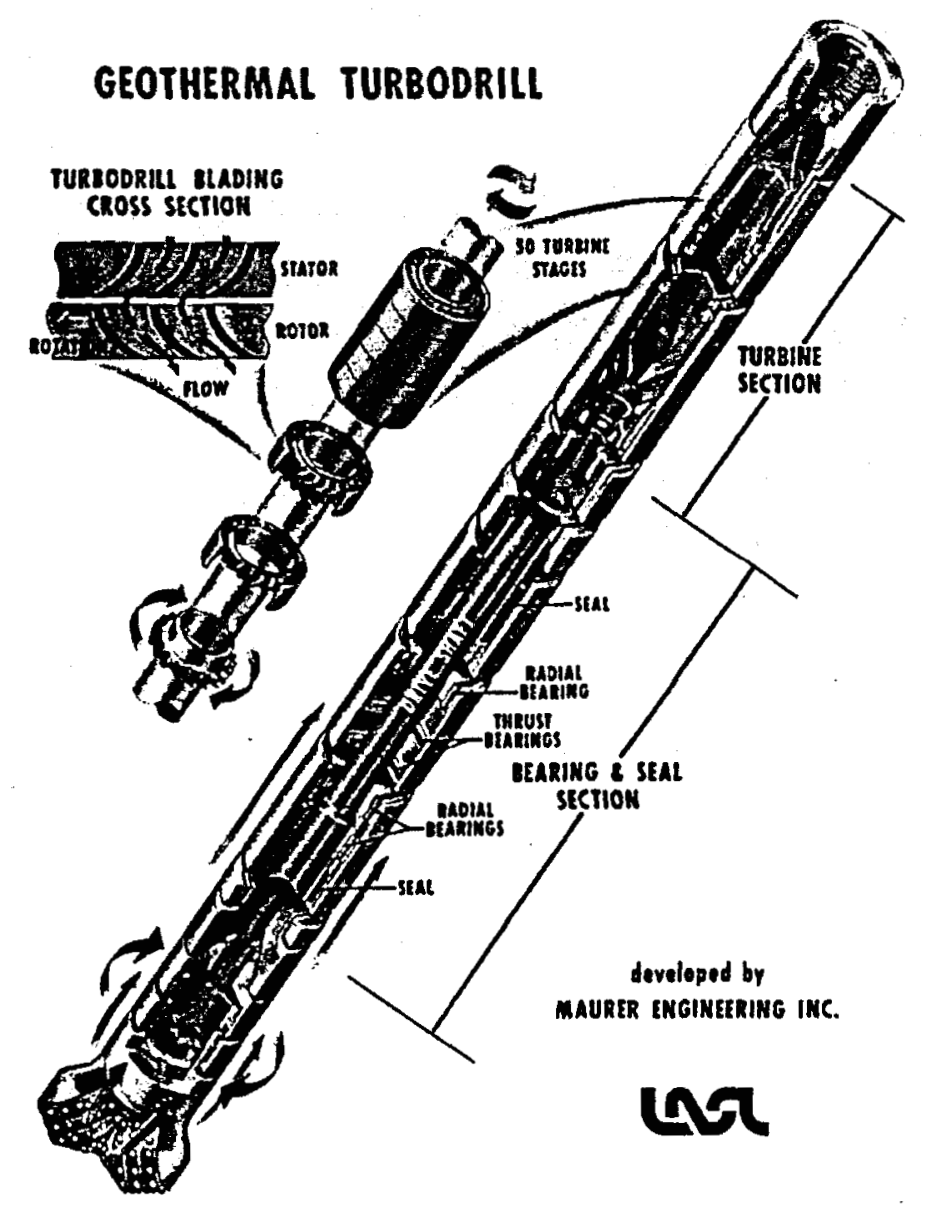

Figure 2-2. LANL Geothermal Turbodrill

The LANL turbodrills performed very well at temperatures up to $325^{\circ} \mathrm{C}$. John C. Rowley (1982) stated that:

"Without the Maurer Turbodrill the EE-1 \& EE-2 Hot-Dry Rock Geothermal Wells could not have been accomplished." 


\section{LANL Turbodrill}

The LANL turbodrills include an upper power section and a lower bearing section. The bearing section has radial and thrust bearings that transfer thrust and bit loads to the housing. Many downhole mud motors use rubber radial and/or thrust bearings that are damaged by high temperatures. The LANL turbodrill used large roller thrust and radial bearings. The upper power section converts hydraulic power in the drilling fluid to mechanical rotary motion by passing fluid through turbine blade sets consisting of a stator and a rotor (Figure 2-3).

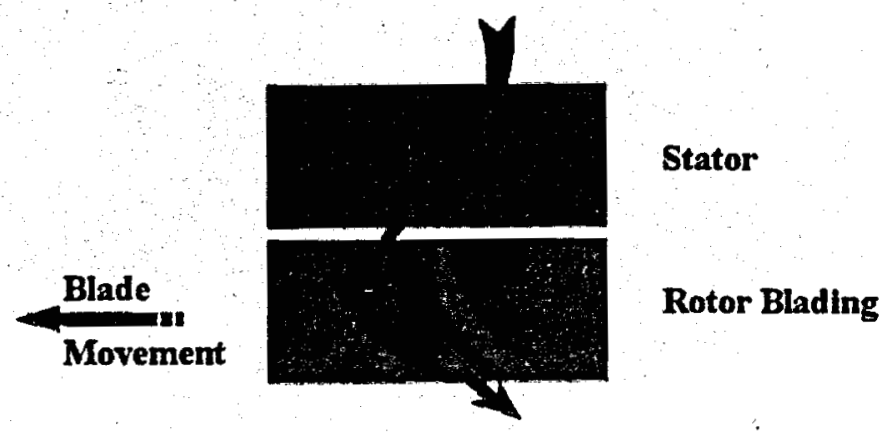

Figure 2-3. Turbodrill Blade Schematic

Fluid is directed by the stator against the rotor, which is connected to the turbine shaft. The fluid causes the rotor to turn the turbine shaft which turns the bit (Figure 2-4).

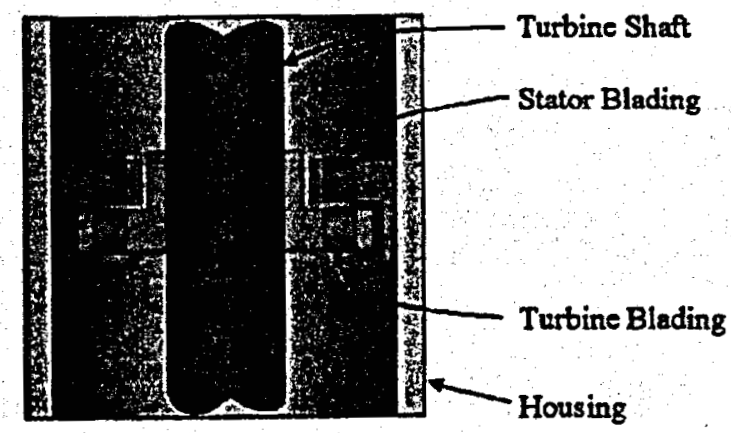

Figure 2-4. Turbine Schematic

The LANL turbodrill blades (Figure 2-5) were designed to produce high power in a short section so that the tool could be used to directionally drill wells using a bent sub at the top of the 
turbodrill. Conventional oil field turbodrills use blades with much less curvature and require large numbers of blades to produce high power. These tools are often 60 to $100 \mathrm{ft}$ long.

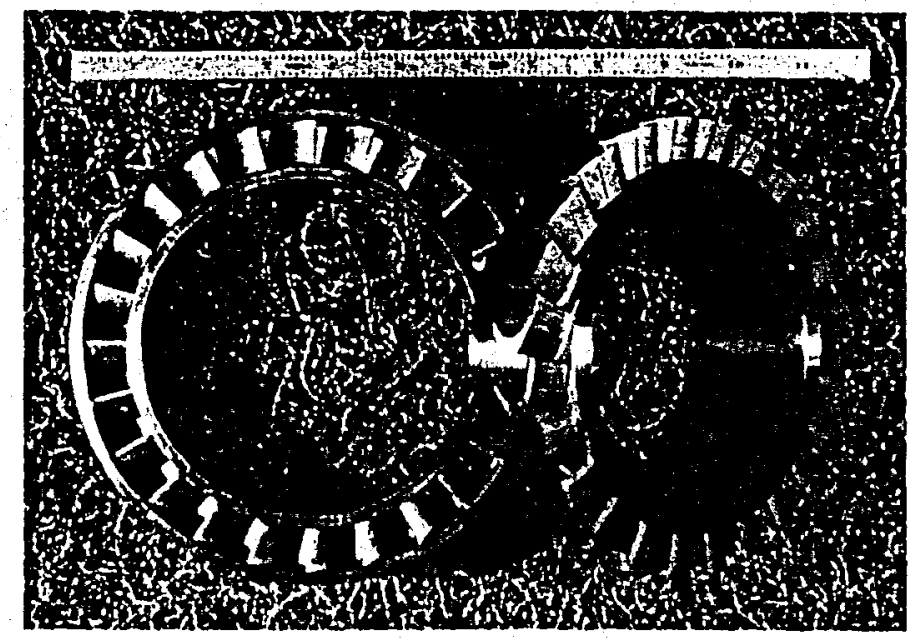

Figure 2-5. LANL Turbodrill Blades

The formations at the LANL's Hot Dry Rock site (Fenton Hill, New Mexico) are hard crystalline granite rock. Bits drill either by shearing the rock (PDC bits) or by crushing it (roller bits) (Figure 2-6). LANL used roller bits on their geothermal turbodrills because of the hard granite formations. PDC drag bits are widely used to drill oil-field rocks, but they would wear rapidly in the hard rocks typically encountered in geothermal wells and therefore could not be used at Fenton Hill.

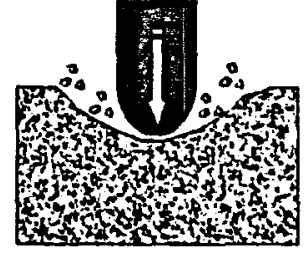

Roller

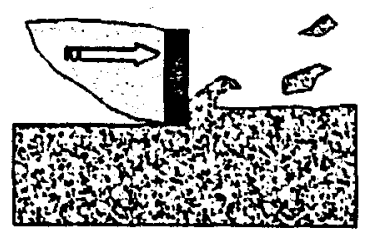

PDC

Figure 2-6. Drill Bit Cutting Mechanisms

LANL operated the geothermal turbodrills at Fenton Hill at a maximum rotary speed of $200 \mathrm{rpm}$ to increase the life of the roller bit bearings (Figure 2-7). The 12/4-inch roller bits required very high bit weights to drill the hard rock at Fenton Hill and, as a consequence, wore out rapidly 
at rotary speeds above $200 \mathrm{rpm}$. The LANL blades were designed with a high entrance angle so that the motors could be operated at speeds compatible with Fenton Hill's drilling requirements.
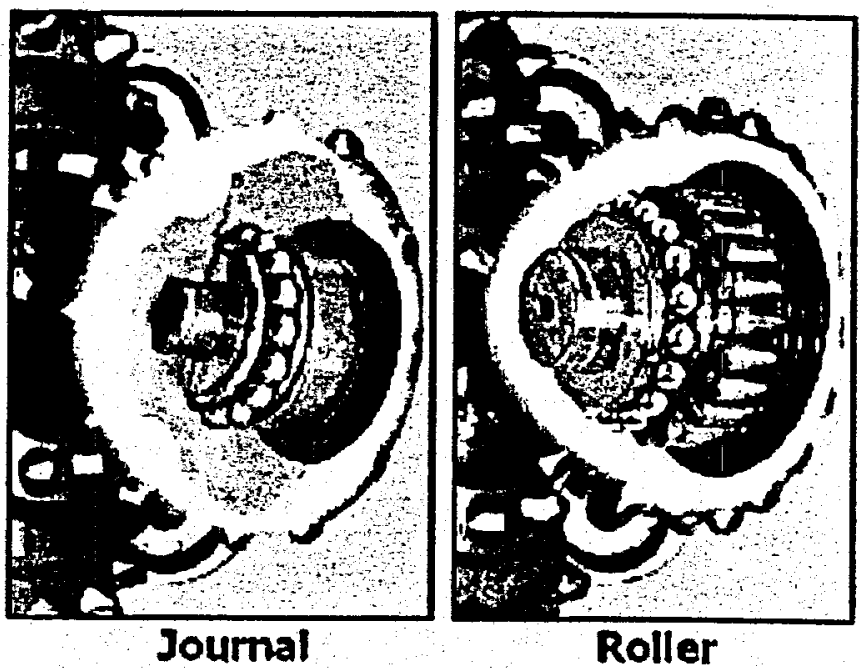

Figure 2-7. Roller Bit Bearings

\section{LANL Turbodrill Performance}

Laboratory dynamometer and drilling tests were conducted using the LANL turbodrills. Figure 2-8 shows the performance of the LANL turbodrills. The curves show that as speed increases the turbodrill torque output goes down, and that maximum power (200 HP) is produced at 1,100 $\mathrm{rpm}$. At $200 \mathrm{rpm}$ the turbodrill only produced $80 \mathrm{HP}$, indicating that much of the turbodrill power went unused in the field.

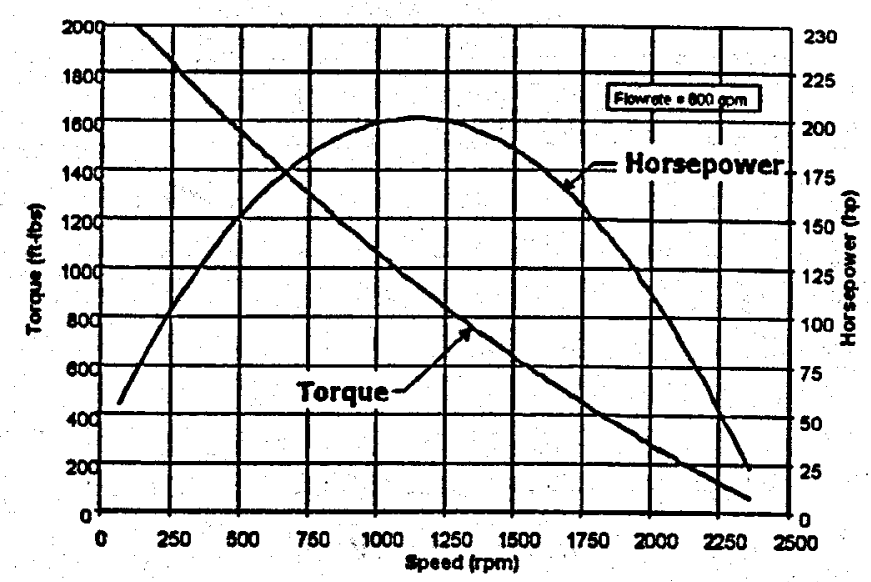

Figure 2-8. LANL Turbodrill Performance Curves 
Prior to drilling at Fenton Hill, LANL conducted a series of drilling tests with the geothermal turbodrills and 121/4-inch insert roller bits in Texas Pink Granite (20,000 psi compressive strength) at TerraTek's Drilling Research Laboratory (DRL) in Salt Lake City, Utah (Figure 2-9). These tests were very successful and showed that the LANL turbodrills could drill hard rocks at very high drilling rates.

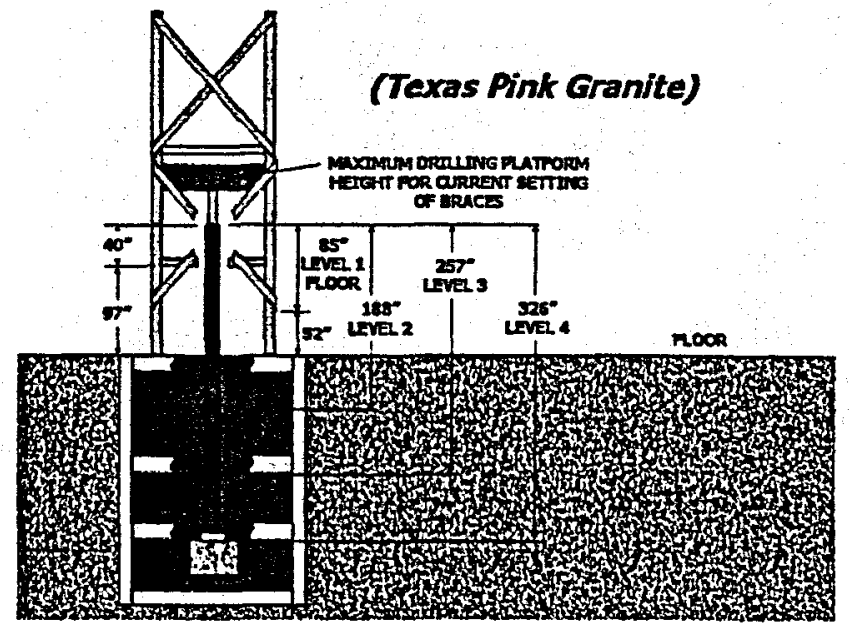

Figure 2-9. LANL Drilling Tests

The DRL tests showed that a 121/4-inch insert roller bit operating in Texas Pink granite at 50,000 lbs weight-on-bit (WOB) required 2,000 ft-lbs torque (Figure 2-10). Figure 2-8 shows that at $250 \mathrm{rpm}$, the LANL turbodrill delivers $1,900 \mathrm{ft}-\mathrm{lbs}$ torque, which is adequate to rotate $12 \frac{1}{4}$-inch bits with $47,000 \mathrm{lbs}$ WOB.

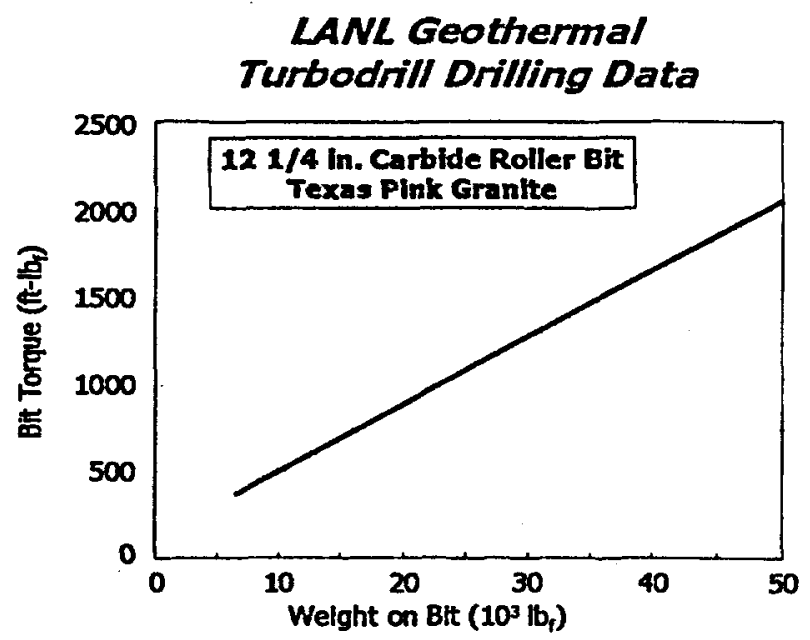

Figure 2-10. LANL Roller Bit Drilling Data 
Figure 2-11 shows that $47,000 \mathrm{lbs}$ bit weight will produce a drilling rate of $40 \mathrm{ft} / \mathrm{hr}$ in Texas Pink Granite.

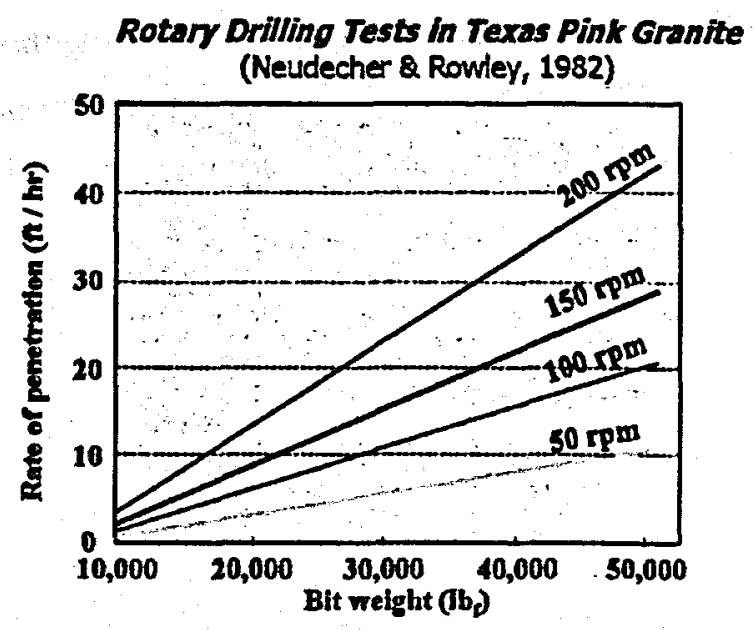

Figure 2-11. Roller Bit Tests

(Neudecher \& Rowley, 1982)

\section{Drilling at Fenton Hill}

The turbodrills performed well at Fenton Hill, but were difficult to operate continuously at low rotary speed due to their low torque output. The turbodrills would stall frequently and could only be restarted by lifting the bit off bottom. Lifting allowed the bits and motors to race to very high speeds, resulting in excessive wear on the bearings and on the gauge of insert roller bits.

In addition, it was difficult to start the turbodrills. The bent sub at the top of the motor forced the bit into the borehole wall. Drag prevented the turbodrills from starting. It was often necessary to stroke the drill pipe up and down several times to free the bit and allow the turbine to start. Weight on bit was used to control the speed of the turbodrill. Although this approach worked, it was difficult to know the exact weight on bit and thus the turbodrill speed. These problems became worse as the well inclination and length grew.

A mud pulse tachometer was also developed and tested at Fenton Hill. This tachometer used partially blocked sets of turbodrill blades to produce a positive mud pulse that was detected at the surface. An oscilloscope that performed a fast Fourier-transform analysis was used to decode the signal. The tachometer worked, but only verified just how difficult it was to accurately control the turbodrill speed using weight on bit. The system lag time was so long that the tachometer was 
effective only as a monitor of turbodrill speed. As a result, despite great care by the drillers, bearing and bit wear were a problem.

The LANL turbodrills were a great technological step in downhole motor development, and the wells at Fenton Hill could not have been drilled without these tools. However, improvements were still needed to make the geothermal turbodrills a commercially viable product. 


\section{Advanced Geothermal Turbodrill}

Maurer Engineering developed an Advanced Geothermal Turbodrill (AGT) for the National Advanced Drilling and Excavation Technology (NADET) at MIT by adding a speed reducer to the LANL turbodrill to increase its torque output and reduce its rotary speed (Figure 3-1). This speed reducer was manufactured by the Vector Tool Company of Edmonton, Alberta, Canada. The addition of the gear reducer makes the AGT ideal for use with roller bits and overcomes the stalling problems encountered at Fenton Hill.

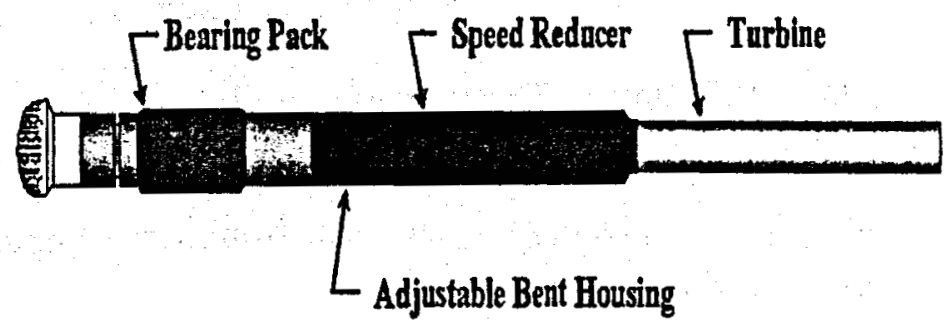

Figure 3-1. Advanced Geothermal Turbodrill

The speed reducer is a planetary style (Figure 3-2). Two stages are used to achieve a 13.6:1 reduction in speed and a matching increase in torque. Figure 3-3 shows a schematic drawing of the gear reducer. The upper stage uses a single set of planetary gears and runs at high speed and low torque. Two sets of planetary gears spaced 12 inches apart are used in the bottom stage of the speed

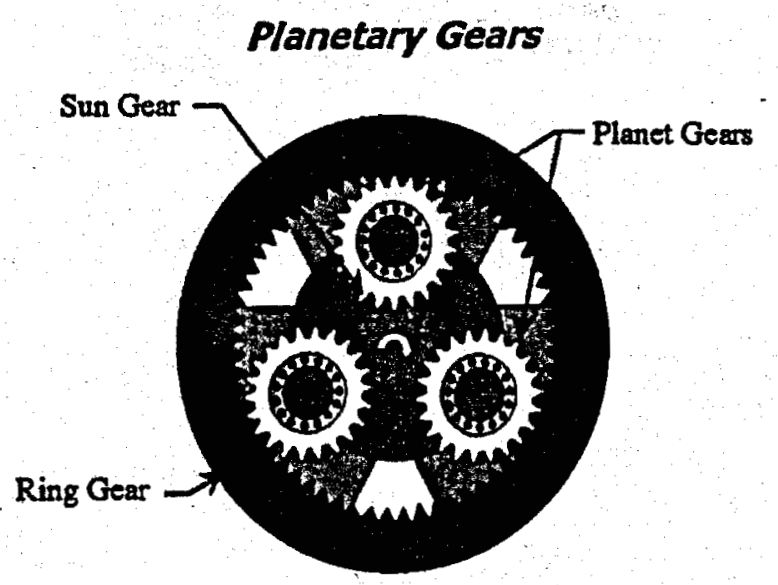

Figure 3-2. Planetary Speed Reducer 
reducer to transfer the high torque (up to $12,700 \mathrm{ft}-\mathrm{lbs}$ ) delivered through these gears to the drill bit and to allow deflection and bending of the turbodrill in directional wells without damaging the gears.

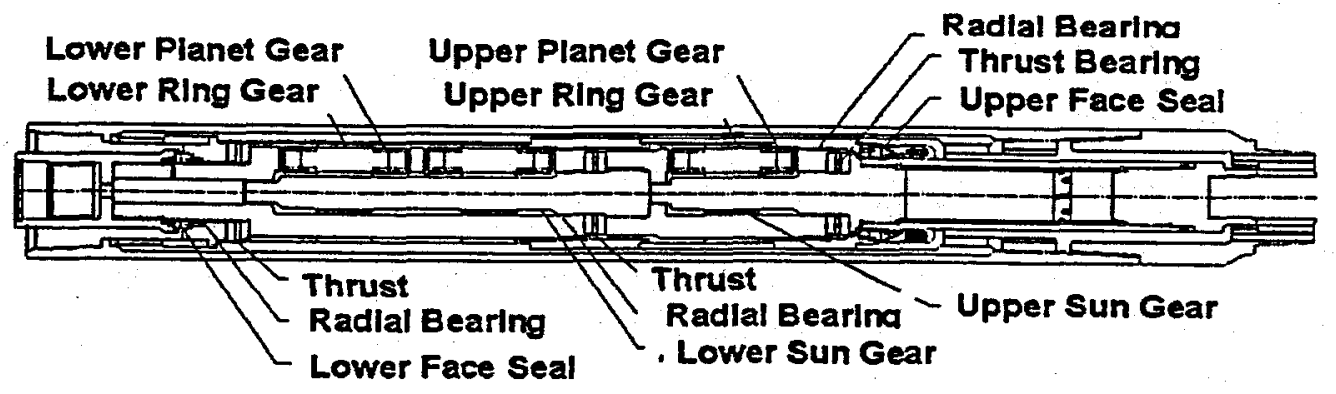

Figure 3-3. Vector Two-Stage Speed Reducer

Figure 3-4 shows the actual gears. The ring and sun gears are made from Astroloy, heat treated to 37 Rockwell $\mathrm{C}(\mathrm{Rc})$ and gas nitrided to a surface hardness of $55 \mathrm{Rc}$. Astrolloy was chosen for its work hardening properties. The planet gears are made from Super Impact steel carburized to $55 \mathrm{Rc}, 0.030$-inch case depth and finish ground.
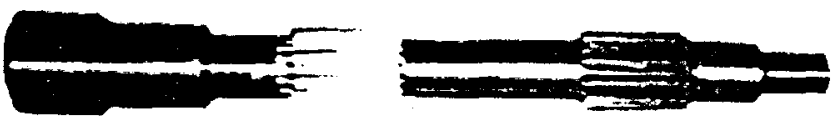

Lower Sun Gear

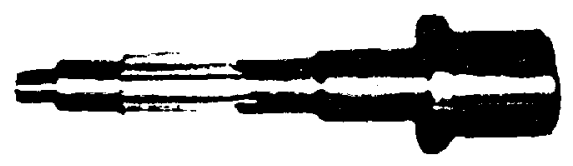

Upper Sun Gear

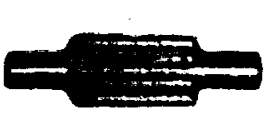

Planet Gear

Figure 3-4. Sun and Planetary Gears 
The improvements made to the LANL turbodrill to produce the AGT are possible because of improved seal technology. Two rotating metallic face seals manufactured by Vector are used to seal oil in the speed reducer. The seals are keyed with dowels and are spring-loaded to prevent separation. The speed reducer is sealed so that the gears can be run in oil. Positive pressure is maintained inside the gear reducer through a proprietary oil system which ensures that any leakage through the seal moves from inside the speed reducer into the borehole, thereby preventing abrasive drilling fluids from entering the speed reducer.

The speed reducer contains a large thrust bearing at the top to absorb the hydraulic downthrust from the turbine section and two center thrust bearings to absorb the weight of the gears and shafts in the speed reducer. A large thrust bearing at the bottom of the bearing pack absorbs the thrust applied to the drill bit ("bit weight").

The addition of a speed reducer allows another improvement for the AGT. The shaft speed below the gear reducer ( 80 to $150 \mathrm{pm}$ ) is now low enough that a flex shaft or flexible coupling can be used to join the gear box shaft to the bearing pack shaft. Flex shafts or couplings could not be used on high-speed LANL turbodrills (200 to $1300 \mathrm{rpm}$ ). The flex shaft or coupling is used with an adjustable bent housing (Figure 3-5). This moves the bend from the top of the turbodrill to just above the bearing pack, improving directional control and making the turbodrill more like conventional mud motors used in oil-field directional drilling.

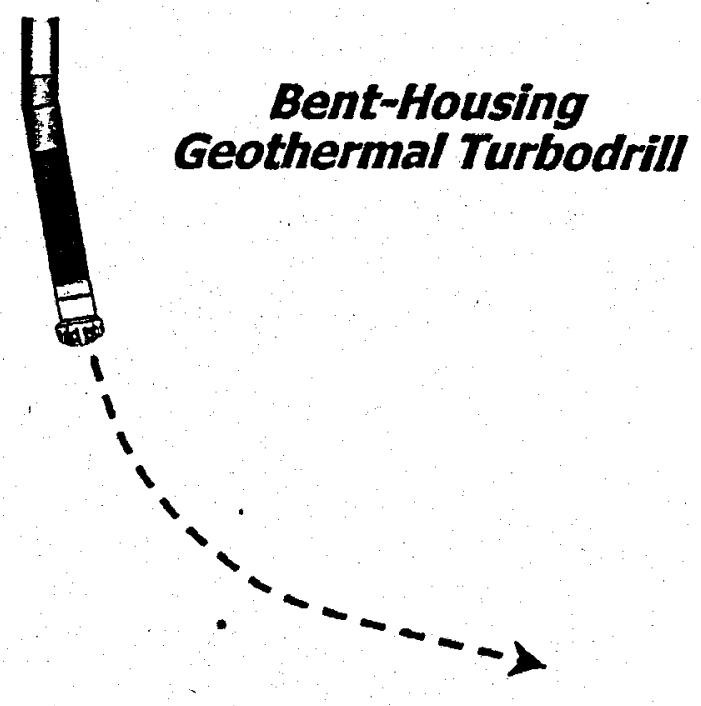

Figure 3-5. Turbodrill with Adjustable Bent Housing 


\section{Laboratory Testing}

\section{AGT Performance}

Extensive laboratory testing was undertaken to evaluate the designs of the AGT and to improve performance and reliability prior to field testing. A key tool in the laboratory testing of the AGT was Vector's dynamometer test stand (Figure 4-1). This dynamometer measures turbodrill torque and speed as a function of flow rate and pressure drop. These values are used to calculate and plot performance curves for the motor.

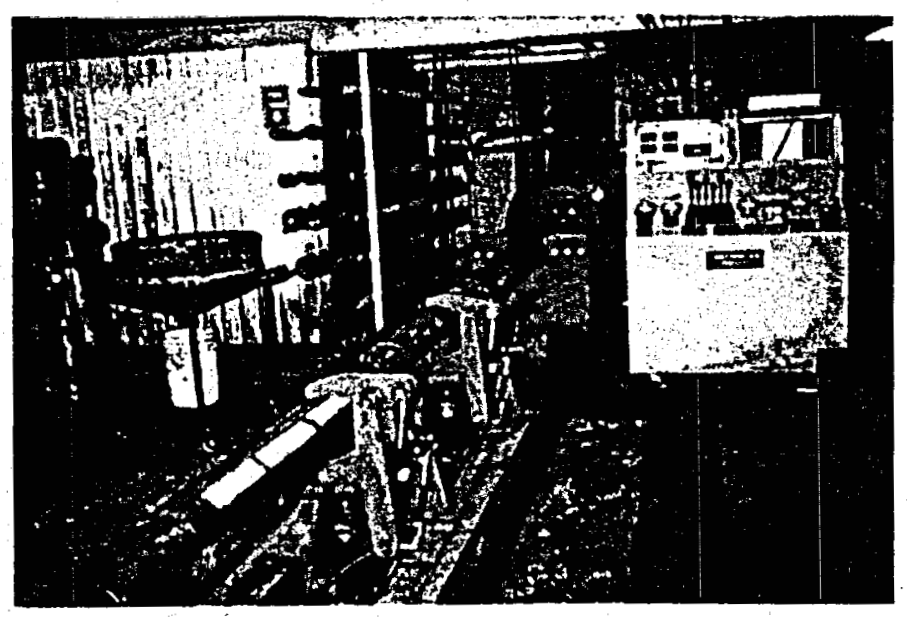

Figure 4-1. Vector Dynamometer Test Stand

Dynamometer tests showed that the AGT delivers 7,500 ft-lbs torque at $85 \mathrm{rpm}$ (Figure 4-2) compared to $900 \mathrm{ft}-\mathrm{lbs}$ at $1,100 \mathrm{rpm}$ for the LANL turbodrill without the speed reducer (Figure 4-3). The speed reducer reduced the turbodrill output speed to a level that is much more suitable for roller bits and the torque has been increased to levels that will allow very high drilling rates and will eliminate the stalling problems encountered at Fenton Hill. 


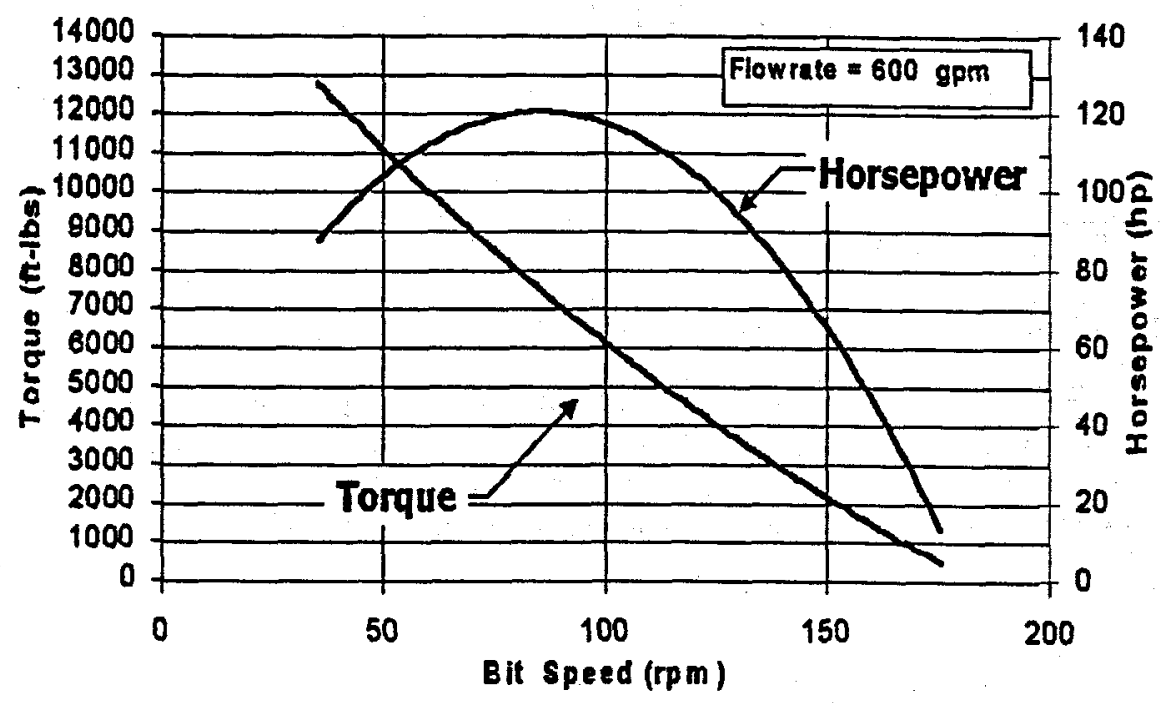

Figure 4-2. AGT Performance with Speed Reducer

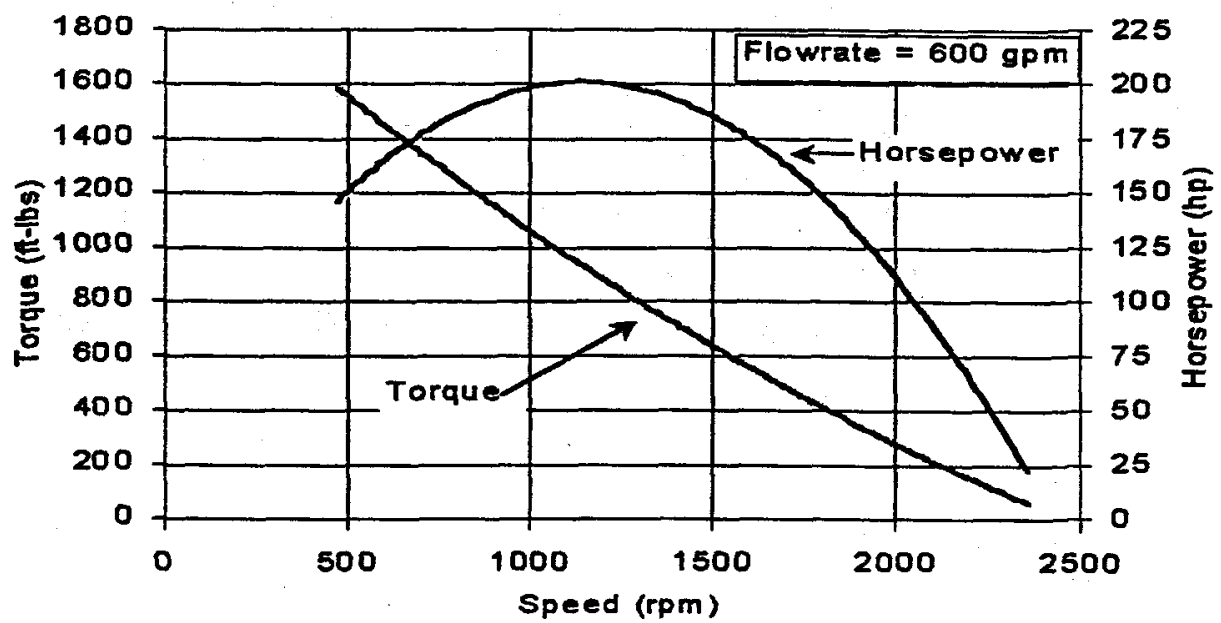

Figure 4-3. AGT Performance without Speed

Reducer (LANL Turbodrill)

With the addition of the speed reducer, the maximum horsepower is decreased from $200 \mathrm{hp}$ to $120 \mathrm{hp}$, because the fluid exiting the stator is no longer at the correct angle to enter the rotor. The original LANL blades were designed with a high entrance angle so that the turbodrill could be operated at speeds $(200 \mathrm{rpm})$ compatible with the 121/4-inch roller bits that were used to drill the hard granite formations at Fenton Hill. In the AGT, the blades are run at speeds corresponding to peak power output. At these speeds, the rotor and stator entrance angles need to be $0^{\circ}$ degrees (Figure 
4-4). To correct this problem, the blades were modified by machining off the old entrance angle to make the new angle zero.

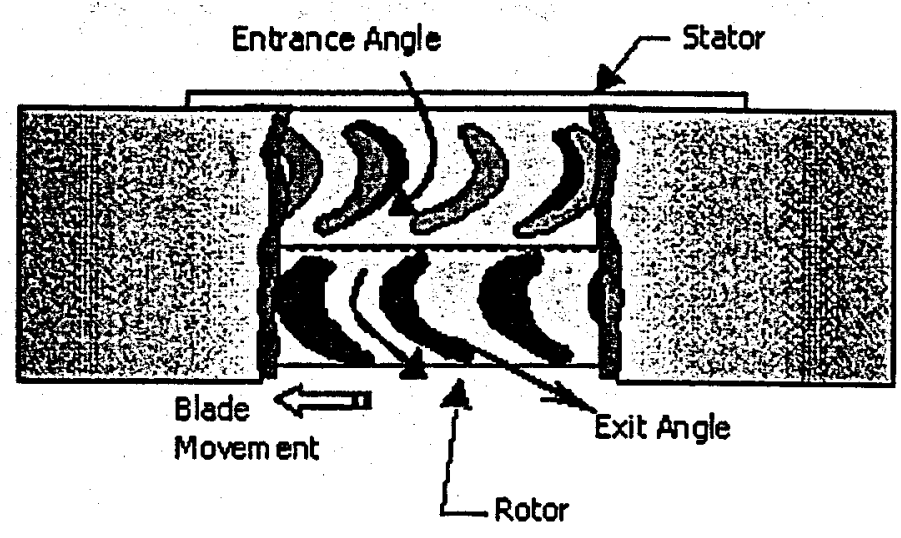

Figure 4-4. Blade Entrance and Exit Angles

Figure 4-5 shows the original and modified blades. Figure 4-6 shows the efficiency curve for the original and modified blades. Efficiency increased from $30 \%$ to $44 \%$ when the entrance angle was changed to $0^{\circ}$.

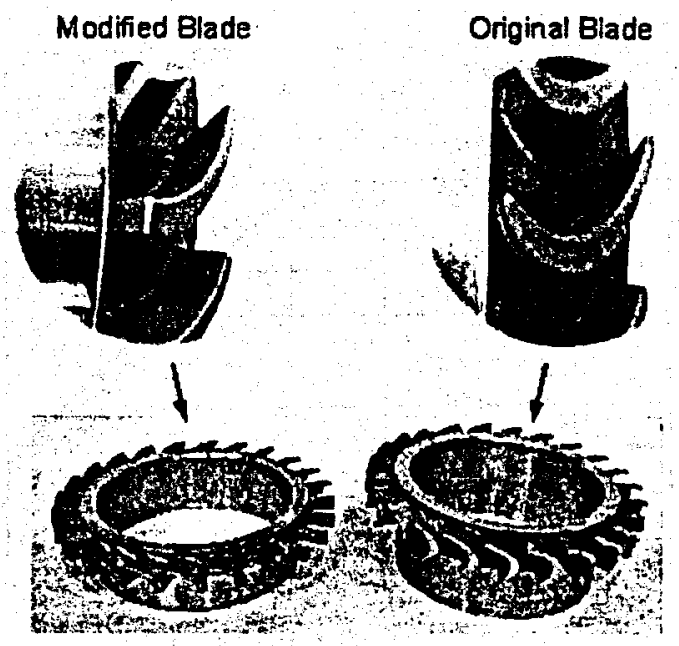

Figure 4-5. Modified AGT Blade and LANL Blade 


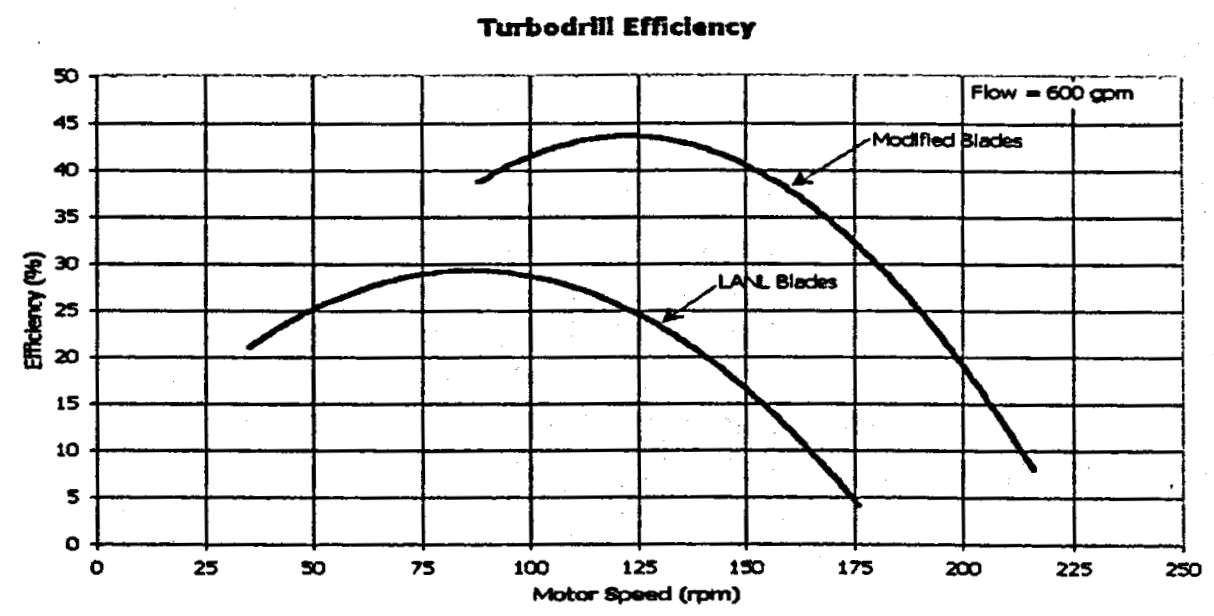

Figure 4-6. Efficiency of LANL and Modified AGT Blades

This increase resulted in a change in performance as shown in Figure 4-7. The maximum horsepower increased from $120 \mathrm{HP}$ to $185 \mathrm{HP}$, the peak horsepower occurs at $115 \mathrm{rpm}$, and the motor produces $8,500 \mathrm{ft}-1 \mathrm{bs}$ of torque at this speed. These operating characteristics make the AGT ideal for use with either roller or PDC bits. The high torque indicates that the motor will not stall even with high weight on bit. Figure 4.8 shows a comparison of torque and speed for the original LANL blades and the modified AGT blades.

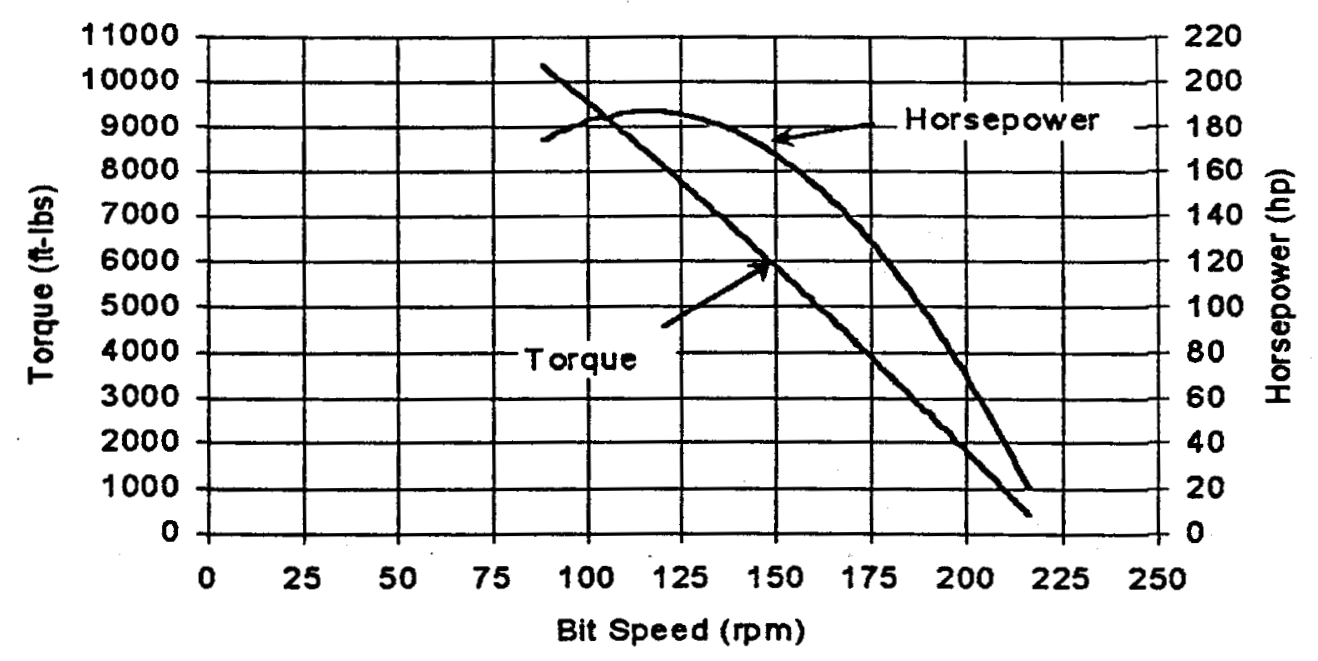

Figure 4-7. Performance of Modified Blade 


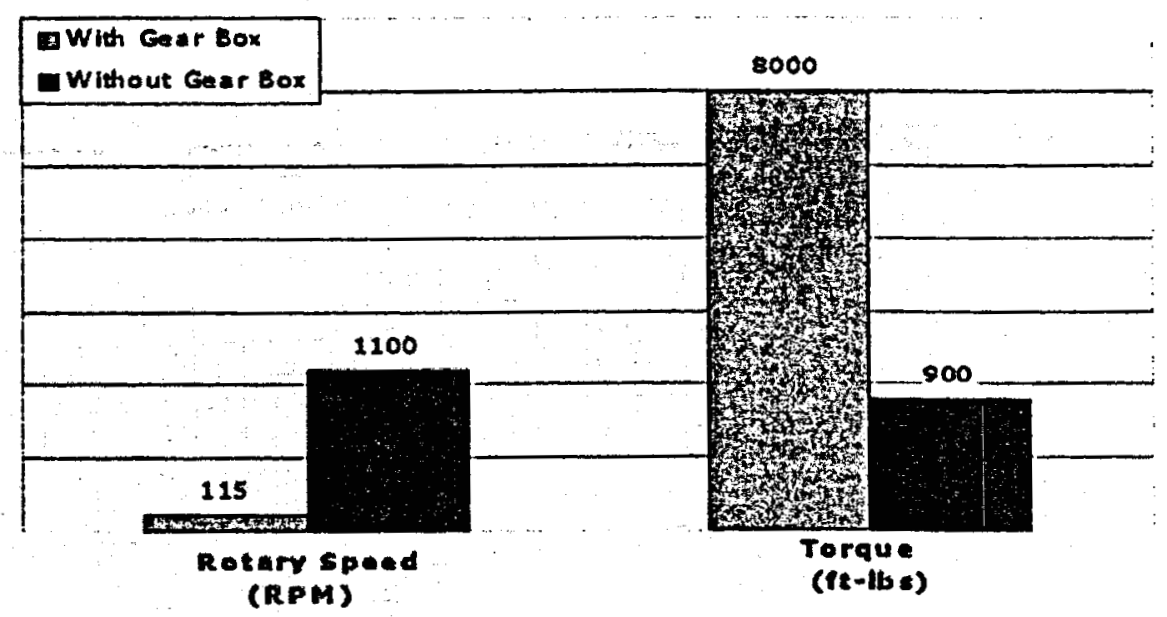

Figure 4-8. Comparison of LANL to AGT Turbodrill

\section{Transmission Efficiency}

One of the concerns about adding a speed reducer was that it would have low efficiency and consume too much power from the turbodrill. Speed reducer efficiency was measured on the dynamometer test stand. Since the operating characteristics are very different between the turbodrill with and without the speed reducer, the data for the tool without the speed reducer were normalized to that with the speed reducer. Figure 4-9 shows the torque versus speed curves for the two conditions. The data show that very little power is lost in the speed reducer. At $115 \mathrm{rpm}$ the torque drops from $10,000 \mathrm{ft}$-lbs to $8,500 \mathrm{ft}$-lbs, making the speed reducer $85 \%$ efficient at this operating speed. The two curves diverge because the speed reducer efficiency decreases as speed increases, because more energy is lost shearing the oil in the speed reducer at higher speed. 


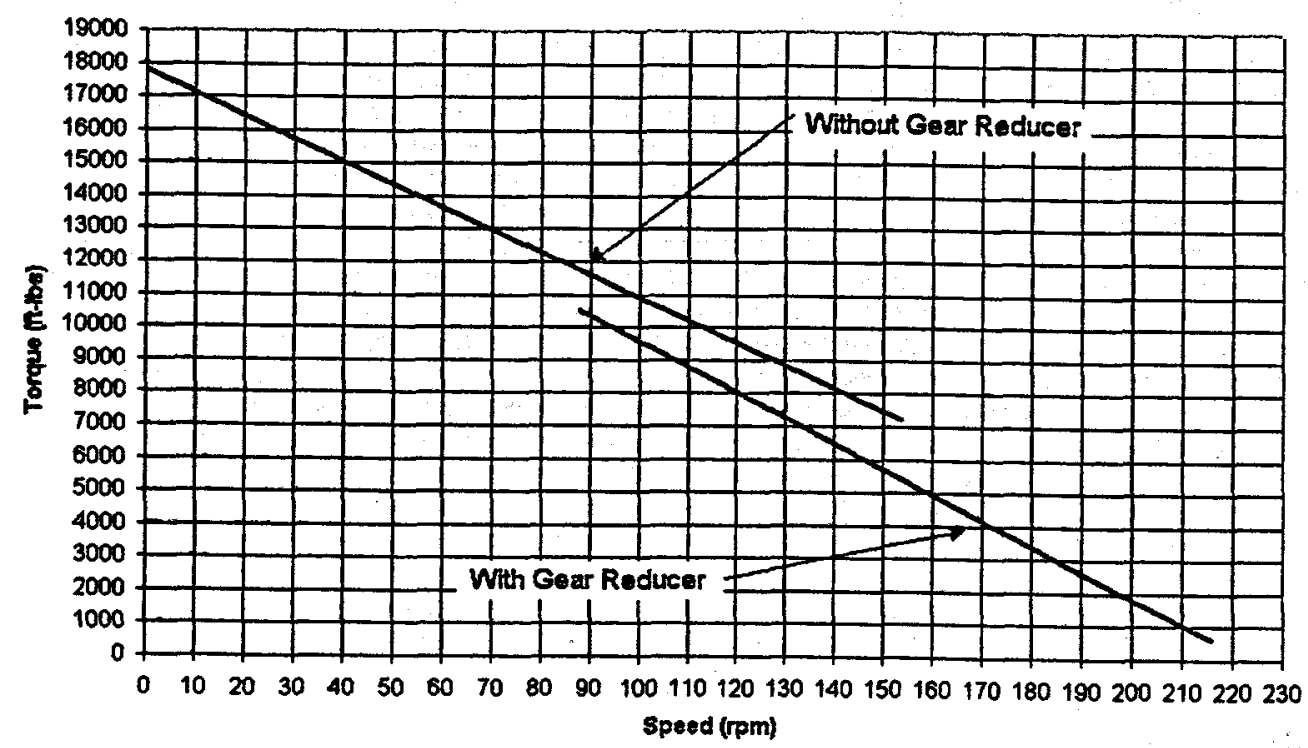

Figure 4-9. Comparison of Turbodrill with and without Speed Reducer

\section{AGT Laboratory Drilling Tests}

Laboratory drilling tests were conducted with the AGT in the Drilling Research Center (DRC) turbodrill drill stand using 121/2-inch insert roller bits in Texas Pink Granite (Figure 4-10). The drilling stand had to be modified for these tests because of the high torque output of the AGT, and the high bit weights needed to drill granite at high rates. Safety was a major concern so the stand

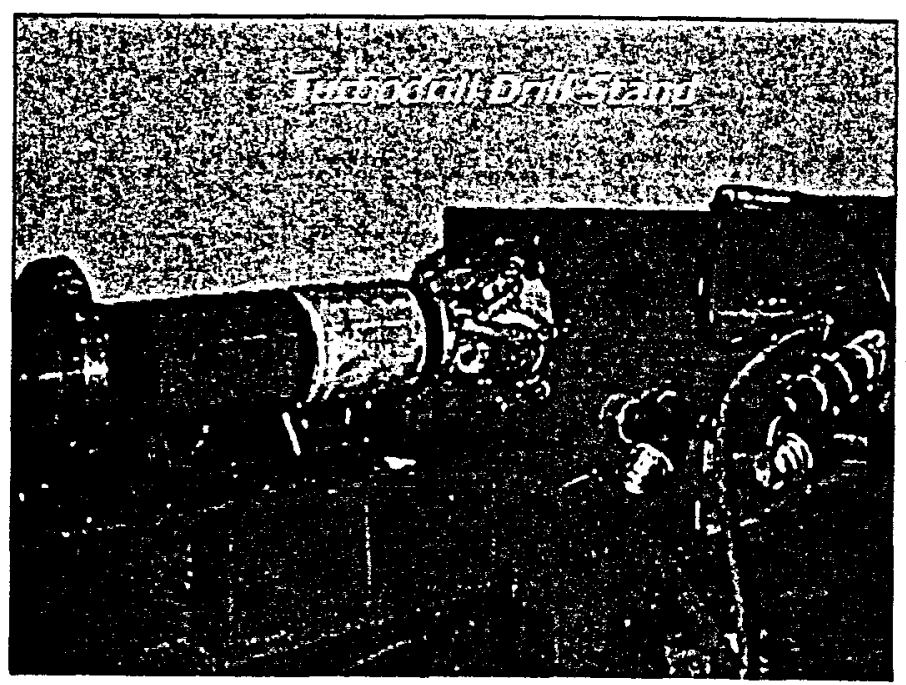

Figure 4-10. DRC Drilling Test Stand 
was modified to carry all the drilling forces within a large steel box (Figure 4-11). Pistons mounted on the side of the box were used to push the test rock into the drill bit to keep all forces aligned to minimize bending moments.

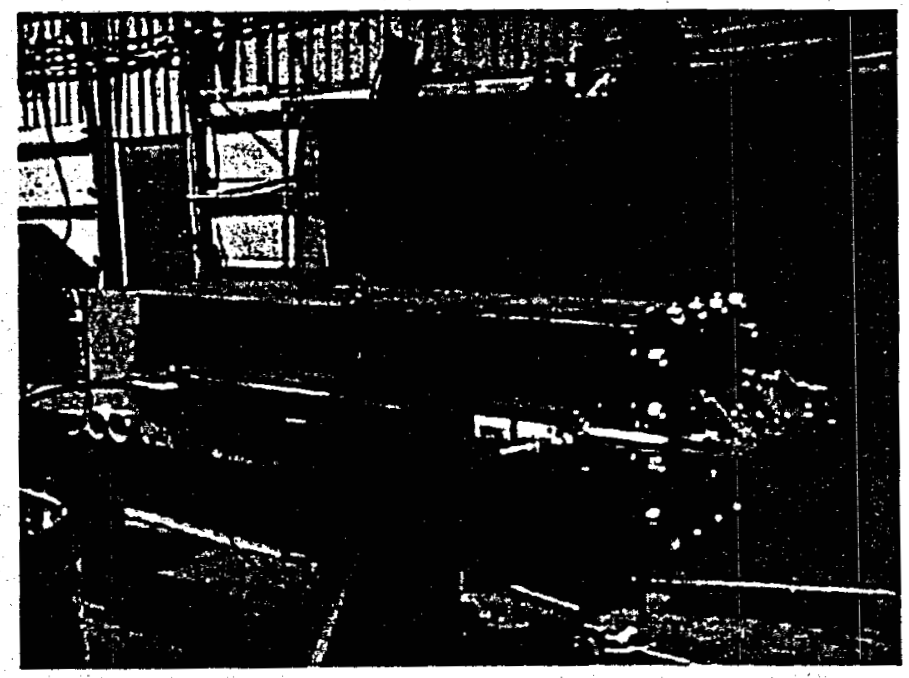

Figure 4-11. Steel Test Box

The motor was attached to the test box through a threaded flange that screwed onto the turbodrill bearing pack (Figure 4-12). This threaded flange is normally used to a attach a near-bit stabilizer if needed. The rock sample was mounted into a frame that uses bearing plates mounted

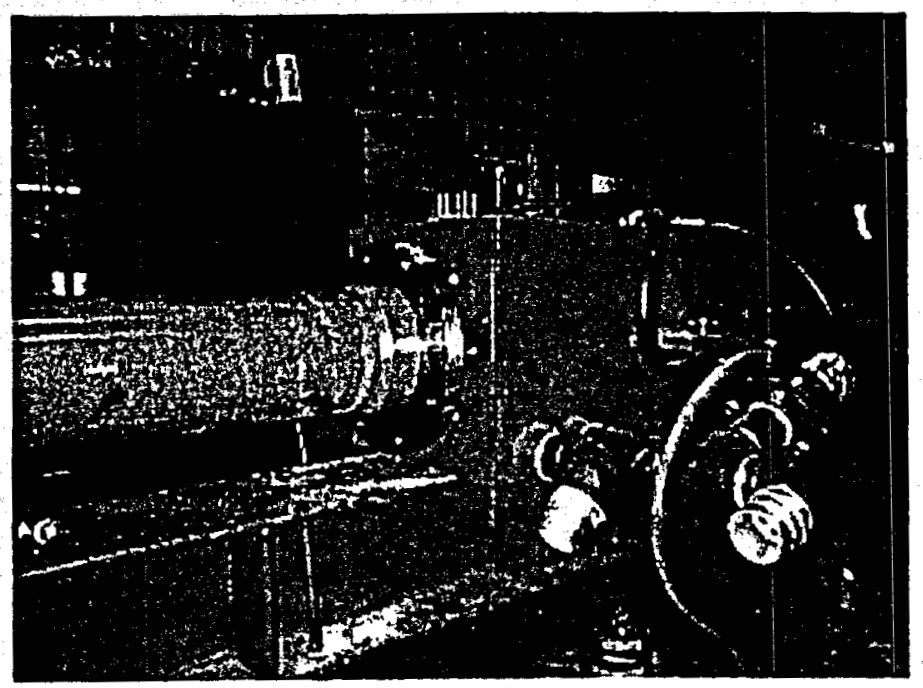

Figure 4-12. Flange on Turbodrill 
on the sides to act as bearings, allowing the rock to slide inside the box. A rod passing through an O-ring seal pushes against the rock in the box, moving it and applying weight to the drill bit.

The drilling test stand includes a computer data acquisition system to collect data and control drilling parameters during the test. The high speed computer allows large amounts of data to be collected in a short period of time. To capitalize on this ability, the computer is programmed to vary bit weight as a function of drilling distance. This allows recording enough data to construct a complete drilling rate versus bit weight curve while drilling only $3 \mathrm{ft}$ of rock sample.

Two 440-HP Ellis Williams oil field triplex pumps (Figure 4-13) are used to provide flow to the DRC drilling test stand. These pumps delivered the high flow rates and pressures needed to operate the AGT at peak power and load.

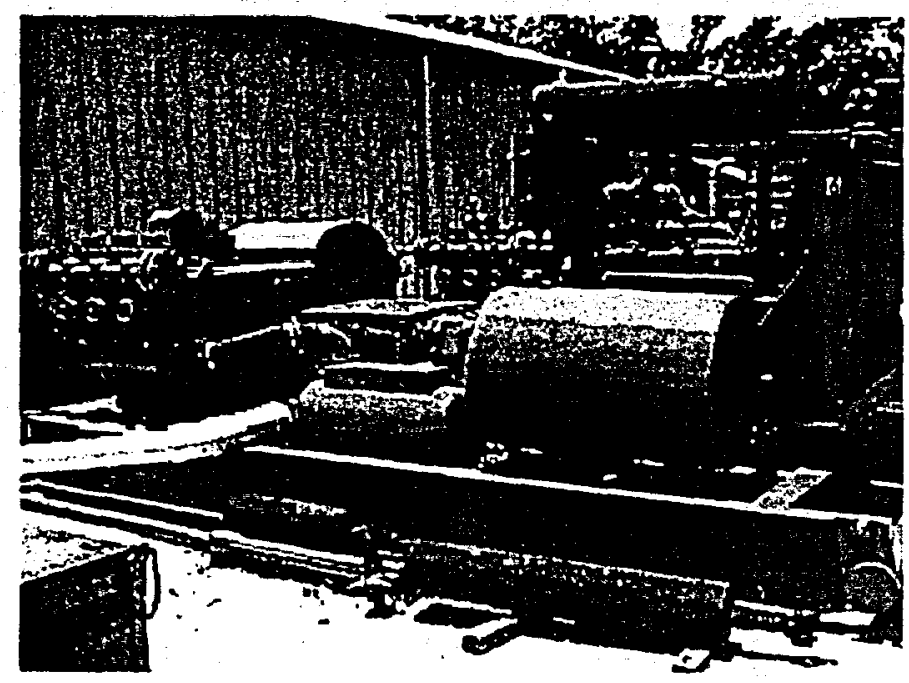

Figure 4-13. Mud Pumps

Figure 4-14 shows a 121/4-inch hole drilled in Texas Pink granite by an insert roller bit. The bit drilled very smooth holes at very high rates in this hard granite. The AGT drilled a maximum of $92 \mathrm{ft} / \mathrm{hr}$ in Texas Pink Granite, compared to $45 \mathrm{ft} / \mathrm{hr}$ with the LANL turbodrill and $42 \mathrm{ft} / \mathrm{hr}$ with a rotary drill as shown in Figures 4-15, 4-16, and Table 4-1. The drilling tests were very successful demonstrating that the AGT can drill hard crystalline rocks at high rates. 


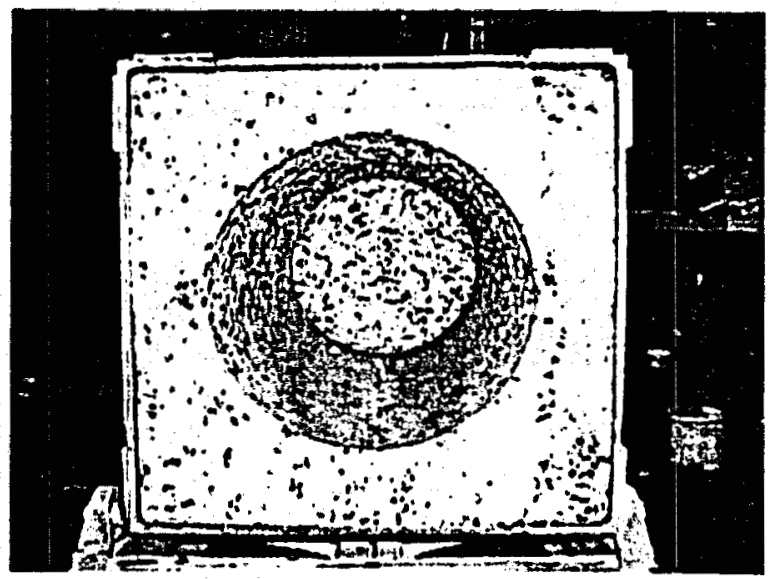

Figure 4-14. 121/4-inch Hole in Texas Pink Granite

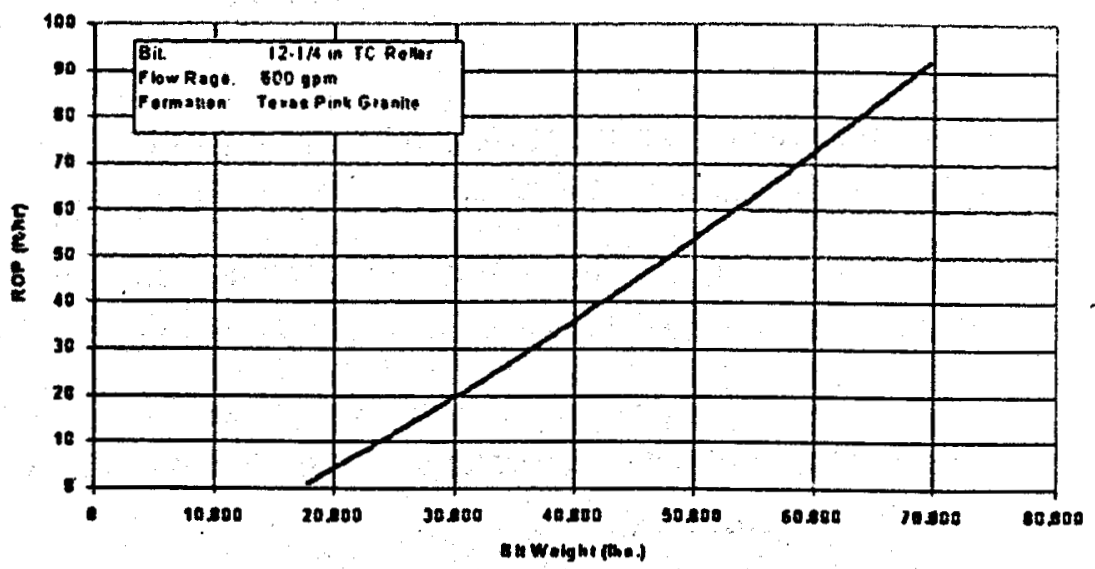

Figure 4-15. AGT Laboratory Drilling Rate in Texas Pink Granite (Cohen \& Maurer, 1999)

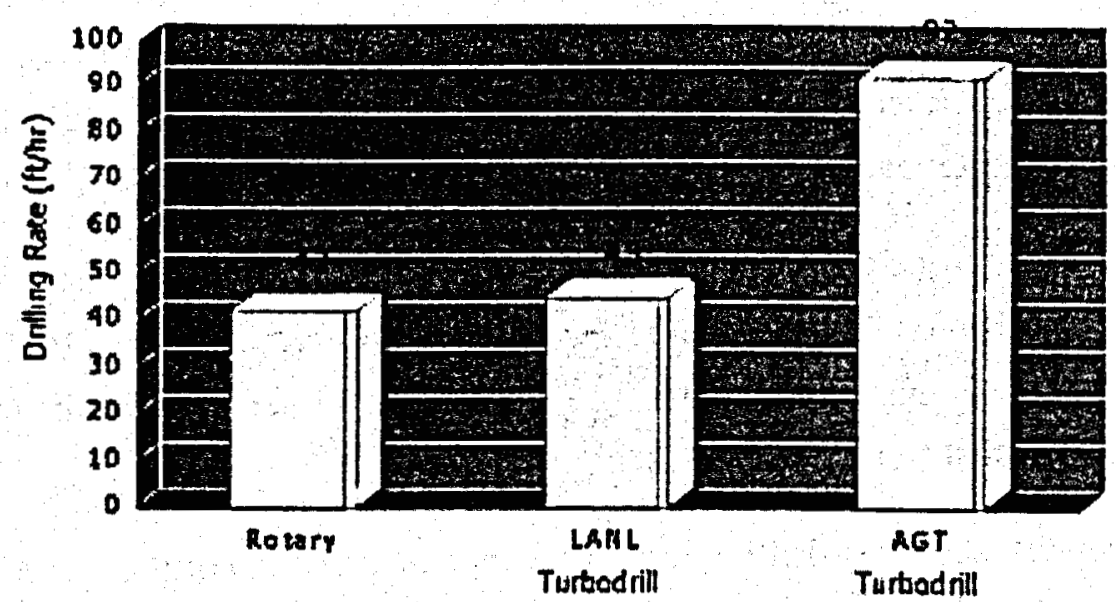

Figure 4-16. 121/4-inch Carbide Roller Bit in Texas Pink Granite (Cohen \& Maurer, 1999) 


\begin{tabular}{|c|c|}
\hline \multicolumn{2}{|c|}{ TABLE 4-1. AGT Drilling Test Conditions } \\
\hline Motor Flow Rate & $600 \mathrm{gpm}$ \\
\hline Motor Pressure Drop (max) & $1,200 \mathrm{psi}$ \\
\hline Motor Speed (approximate) & $100 \mathrm{rpm}$ \\
\hline Motor Torque (approximate) & $9,500 \mathrm{ft}-\mathrm{lbs}$ \\
\hline Motor Horsepower & 180 \\
\hline Weight On Bit & 10,000 to $70,000 \mathrm{lbs}$ \\
\hline Bit Type & Tungsten Carbide Tri-Cone Roller \\
\hline Rock Type & Texas Pink Granite \\
\hline Rock Strength & $20,000 \mathrm{psi}$ (compressive) \\
\hline Drilling Rate (max) & $92 \mathrm{ft} / \mathrm{hr}$ \\
\hline
\end{tabular}

As previously discussed in this report, the LANL turbodrill was difficult to start in LANL's hot, dry wells because of low torque output. Laboratory tests were conducted to test the ability of the AGT to start under load, such as with bit drag on the side of the hole in a directional assembly. Pumping was stopped and 60,000 pounds weight was applied to the roller bit. Flow was then slowly increased from zero. At $300 \mathrm{gpm}$ (half the rated flow of $600 \mathrm{gpm}$ ), the motor started and continuously rotated the bit, showing that the high torque output of the AGTwill make operation of the tool much simpler under field conditions.

High torque output is also important for normal drilling because it will allow operating the AGT at its most efficient drilling speed, which maximizes penetration rates. In earlier LANL tests, drilling with the LANL turbodrills was difficult since there was no positive indication at the surface when the tool stalled. The only way to verify that the motor was running was to conduct a drill-off test to see if bit weight declined with time. Unfortunately, these tests are time consuming and the motor must be restarted after each stall, slowing drilling rate even further.

The AGT's high torque capability overcomes the stalling difficulties encountered with the LANL turbodrills in the Fenton Hill wells. It is very difficult to stall the geared AGT under normal drilling operations even with high bit weights. The high torque will ensure that the motor keeps on drilling, eliminating the lost time of drill-off tests and restarting.

These successful laboratory drilling tests show that the AGT can drill hard rocks at very high rates and that the bent housing and low rotary speed make it ideal for drilling vertical and horizontal wells in deep, hot geothermal formations. The success of the laboratory tests demonstrated conclusively that the AGT was ready for full-scale field testing. 


\section{Turbodrill Design Computer Program}

The AGT is a very flexible directional drilling motor that can run under a variety of conditions and different mud rheologies. As mud properties vary, the number of stages (a stage consisting of one rotor and one stator) can be adjusted to provide the desired pressure drop, motor speed, and horsepower characteristics. MEI developed a proprietary computer program, TURBO, to calculate turbodrill performance under differing conditions. This program was initially written for turbodrills without speed reducers. During this project, TURBO was modified to include speed reducer parameters, including reduction ratio and efficiency. The program uses a combination of measured and empirically determined variables. Input variables are iterated until the program output matches data measured on the dynamometer test stand.

Figure 5-1 shows the TURBO input screen and the parameters used to predict the performance of the AGT. Input parameters are described below.

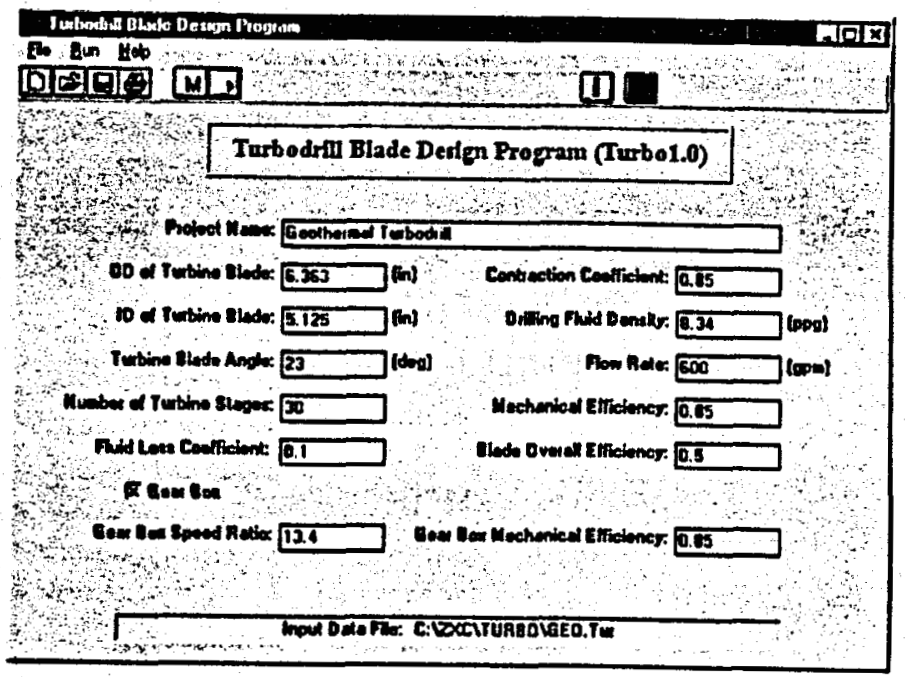

Figure 5-1. TURBO Input Screen

1. OD of Turbine Blade - This is the maximum diameter of the working portion of the rotor blade. It does not include confinement rings on the outside diameter of the blade.

2. ID of Turbine Blade - This is the minimum diameter of the working portion of the rotor blade. It does not include the center collar of the rotor. 
3. Turbine Blade Angle - This is the exit angle of the rotor and stator (Figure 4-4), which affects speed and power. The higher the angle, the higher the power and speed.

4. Number of Turbine Stages - This is the number of stages of turbine blades. By stacking more blades, the turbodrill power output can be increased linearly, but the tool's pressure drop will also increase.

5. Fluid Loss Coefficient - This is the decimal equivalent of the percentage of fluid that leaks by the blades without doing work. It is difficult to determine the exact value empirically, but 0.1 or $10 \%$ is a good approximation.

6. Contraction Coefficient - This represents the flow area that remains open through the turbine blades. A good starting value is 0.85 or $85 \%$.

7. Drilling Fluid Density - This is the density of the drilling mud that will be run through the turbodrill. Higher weight muds produce more power and higher pressure drops than lighter muds.

8. Flow Rate - This is the flow rate pumped through the turbodrill. The turbodrill has the capability of bypassing fluid through the center of the rotor shaft. This flow rate would not include any bypassed fluid.

9. Mechanical Efficiency - This is a measurement of the losses due to bearings and friction. It can be adjusted using dynamometer data, but is difficult to separate from total efficiency. A value of 0.8 or $80 \%$ is a good starting point. This value does not include loss in the gear box, which is entered separately.

10. Blade Overall Efficiency - This is the efficiency of the entire turbodrill and is the product of mechanical efficiency and hydraulic efficiency. Values for turbodrills are approximately 0.5 or $50 \%$.

11. Gear Box Speed Ratio - This is the ratio of the speed reducer. It can be determined by rotating the input of the speed reducer and counting the output revolutions.

12. Gear Box Mechanical Efficiency - This is the mechanical efficiency of the gear box under the same conditions that will be found in the hole. This value was measured for the AGT as 0.85 or $85 \%$ efficient. 
After these data are input, TURBO produces the output shown in Figure 5-2. Output is presented in several useful formats including tabulated data (Figure 5-3) and graphical output (Figure 5-4). As discussed in Chapter 4, the input angle on the blades when running at peak power is straight, or $0^{\circ}$. However, TURBO uses a horizontal frame of reference, so fluid exit angle is $90^{\circ}$.

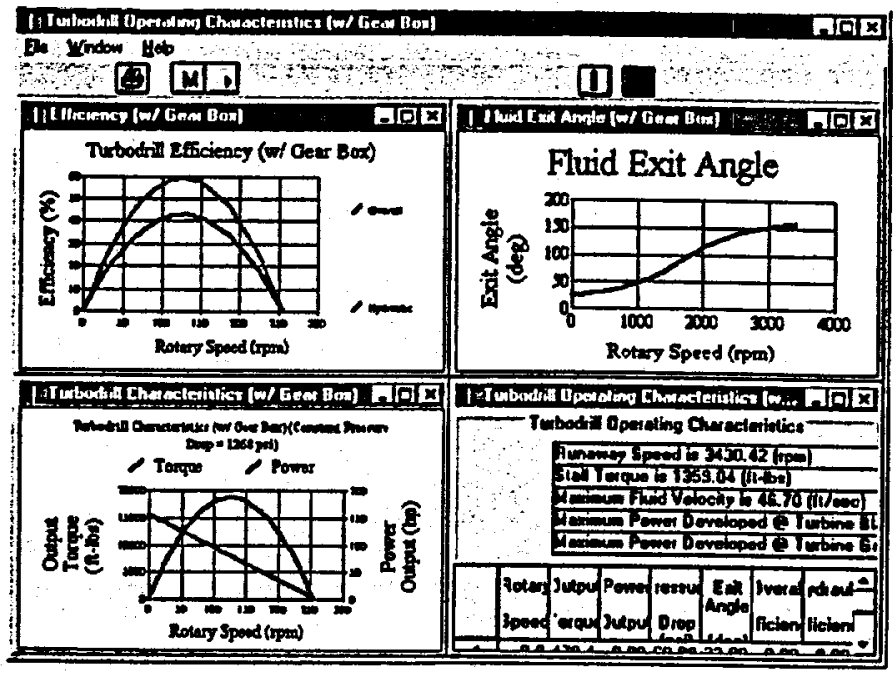

Figure 5-2. TURBO Program Output Screen

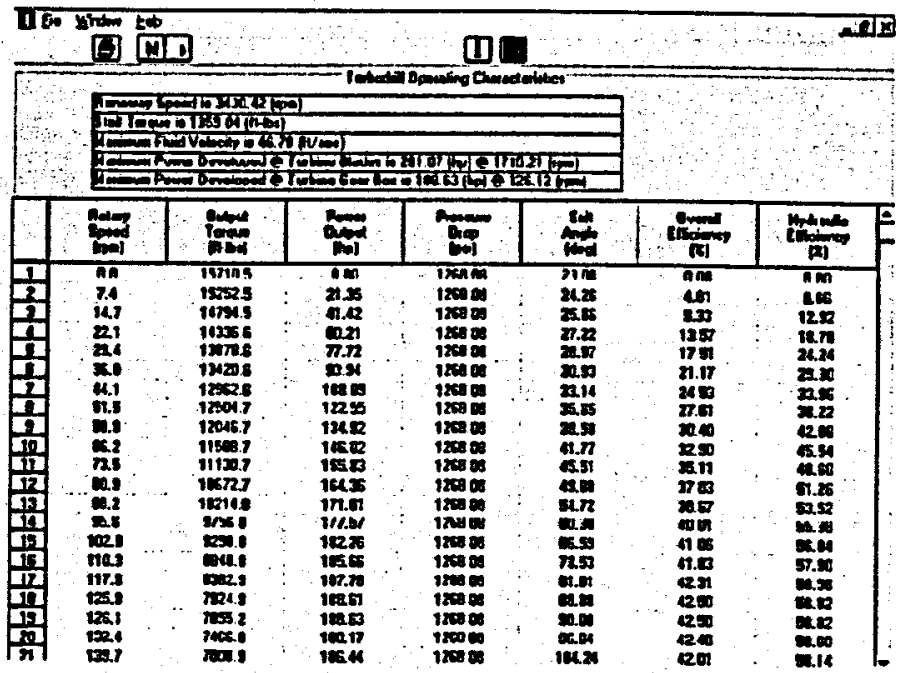

Figure 5-3. Tabular Output of TURBO 


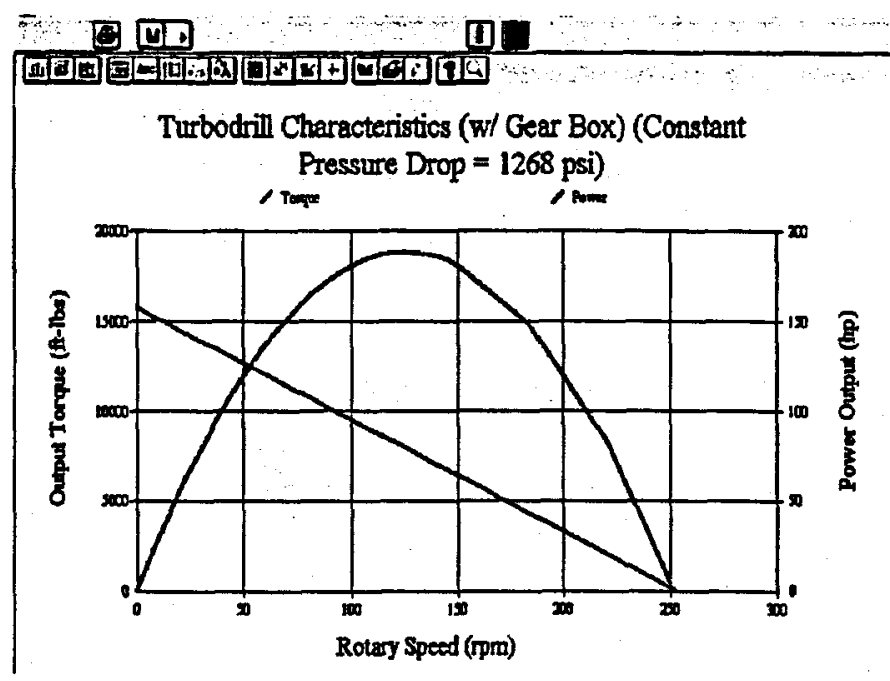

Figure 5-4. Graphical Output of TURBO

Table 5-1 shows that after initial calibration of TURBO using dynamometer data, the program predicts values very close to the measured values, indicating that it can predict the performance of the AGT according to its blade design and field operating conditions.

TABLE 5-1. Comparison of TURBO Predictions with Measured Data

\begin{tabular}{|l|c|c|}
\hline \multicolumn{1}{|c|}{ Parameter } & Predicted & Measured \\
\hline Power Output (hp) & 189 & 188 \\
\hline Overall Efficiency (\%) & 43 & 43 \\
\hline Torque (ft-lbs) & 7,925 & 7,700 \\
\hline Rotary Speed (rpm) & 125 & 125 \\
\hline Pressure Drop (psi) & 1,268 & 1,270 \\
\hline
\end{tabular}




\section{Pre-Field Test Trip}

At the conclusion of the laboratory testing, plans were made to field test the AGT. The most desirable location would have been a geothermal well, but in 1999 the industry was experiencing a major consolidation and little geothermal drilling was taking place in the United States. In addition, the United States oil industry was in a slump and there was also very little oil and gas drilling. PEMEX offered to help test the tool because some Mexican oil fields have hot wells and PEMEX needs motors to drill these wells in addition to their geothermal wells. This test would provide PEMEX engineers and drillers the opportunity to observe the AGT at minimal expense.

A trip was made by MEI engineers to Reynosa, Mexico to discuss the proposed test. They met with Engineer Baudelio Prieto, manager of Burgos project in the North zone. He explained what information was needed in requesting a test and where to send the information within PEMEX headquarters. A preliminary test plan was written and submitted to PEMEX, where it was approved.

A formal contract was signed between PEMEX and MEI to test the advanced geothermal turbodrill in PEMEX's North zone. The North zone is administered out of Reynosa, Mexico which is located across the border from McAllen, Texas. The preliminary test plan was made into an official project report (MEI's No. TR99-20) entitled "Advanced Geothermal Turbodrill Field Test Plan" dated June 1999. An English translation of the contract between MEI and PEMEX to conduct the test is contained in Appendix A.

The importance of this test required that maximum care be taken in planning. A trip was scheduled to view candidate PEMEX rigs for the test and to speak with key PEMEX personnel. In August 1999, three engineers from MEI traveled to Reynosa, Mexico to visit a PEMEX drilling site and to meet with PEMEX engineers to discuss the AGT field test. After reviewing the preliminary test plan with the PEMEX engineers, MEI engineers visited PEMEX rig 4002 shown in Figure 6-1. 


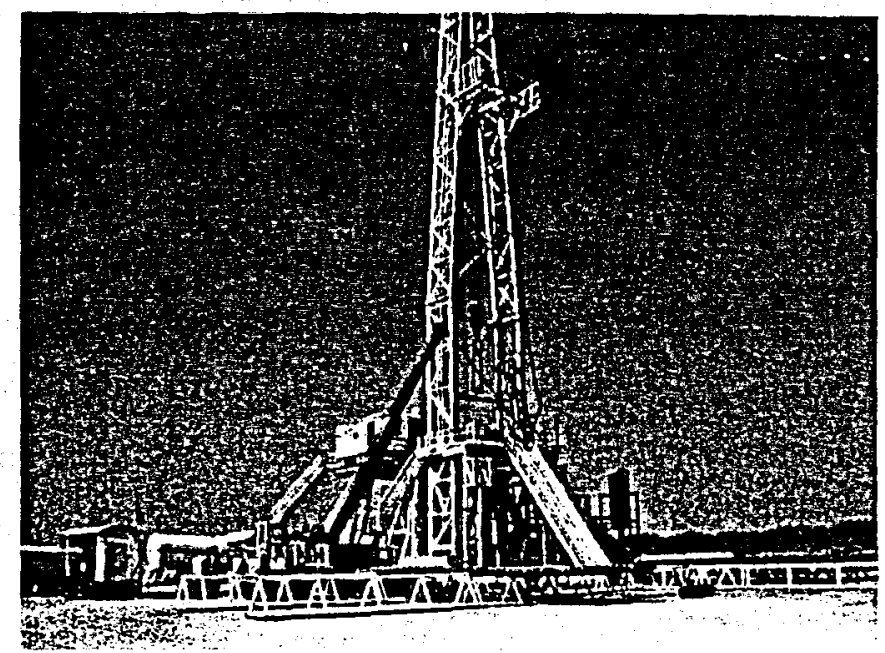

Figure 6-1. PEMEX Rig 4002

It was not possible for PEMEX to predict which of their rigs would be used on the test. However, they did know the class of rig that would be used and so they selected the smallest rig in that class for this visit. In this way, if MEI determined that this example rig was sufficient, all other rigs that might be used would also be acceptable. The main concern was whether sufficient hydraulic capacity was available to supply the AGT with the flow and pressure necessary to operate at high power levels. It was also necessary that surface equipment be able to handle the increased surface pressures that would occur with the turbodrill in the bottom hole assembly.

While visiting the rig, it was discovered that Baker Hughes was supplying the bits to PEMEX for wells in this field, and that a 121/4-inch PDC bit would be used on the field test. A new bit was on site and is shown in Figure 6-2. It has six blades and six nozzles and an IADC code of M323.

Figure 6-3 shows a specification sheet for the bit.

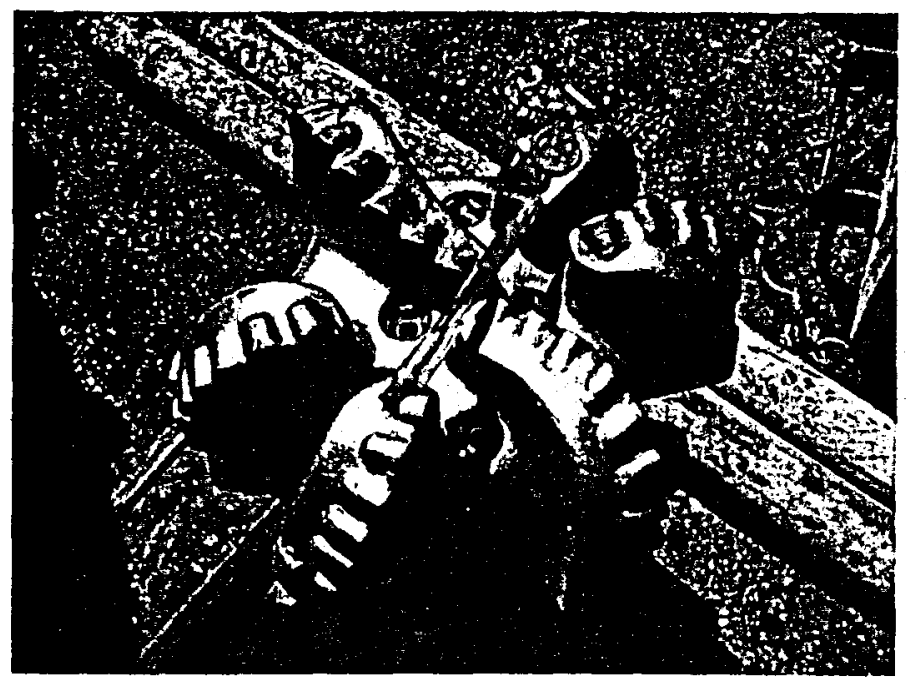

Figure 6-2. Baker Hughes PDC Bit 


\title{
$121 / 4 "$ BD536
}
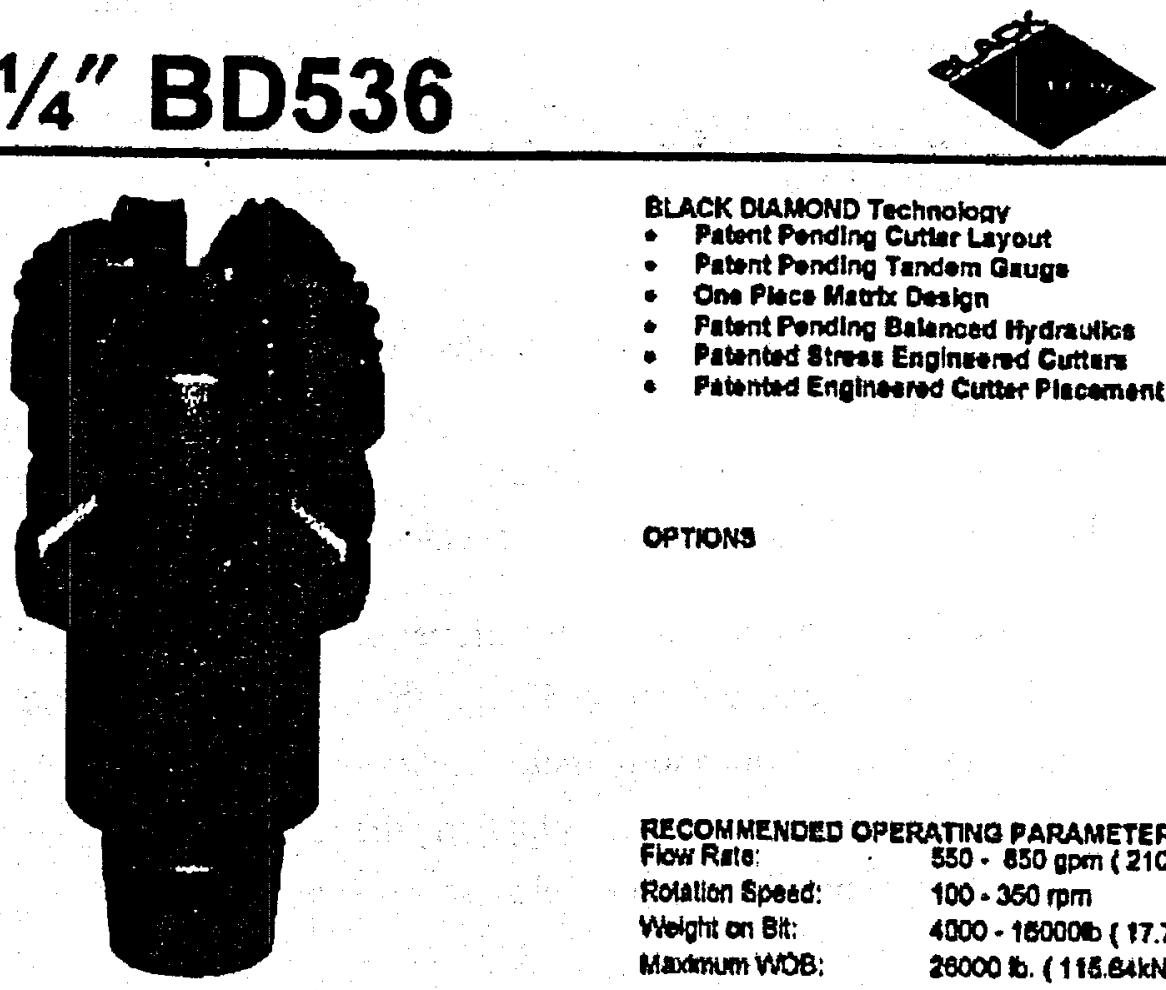

\author{
BLACK OLAMOND Technology \\ - Patont Pending Cuttar Luyout \\ - Patent Ponding Tandom Gruge \\ - On Plice Matrx Desion \\ - Patent Pondino Bulanced trudrautios \\ - Patunted 8tras Englncend Cutrers \\ - Pathitud Engthesrod Cutter Placement
}

Oprions

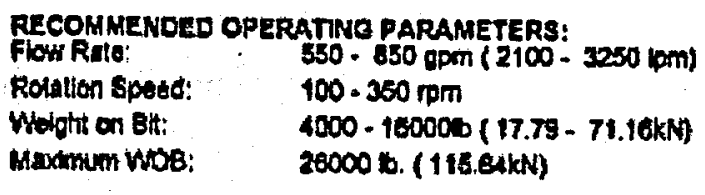

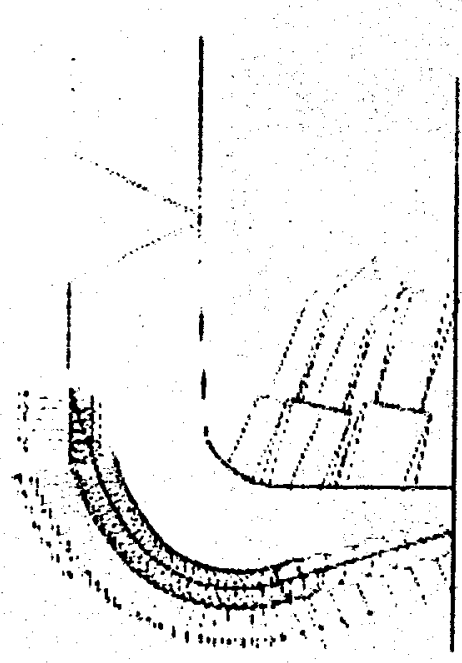

\section{PROOUCT 8PECIFICATIONS}

ADC Coda:

Number of Blades:

Number of Nozdis:

Total Number of Cutless:

Faco Cuttur Quantly:

Back Roke (Cons);

Back Rata (Nowe):

Back Rtak (stroulder):

Back Roks (Gage):

Primary Gauge Length Typa:

Becondary Caupo LenothrTypa:

Junk siot NioarRatio:

Fus Volumeriatlo:

Overath Length:

Length to shouldex:

Makeus Torque:

API Pin Connection:

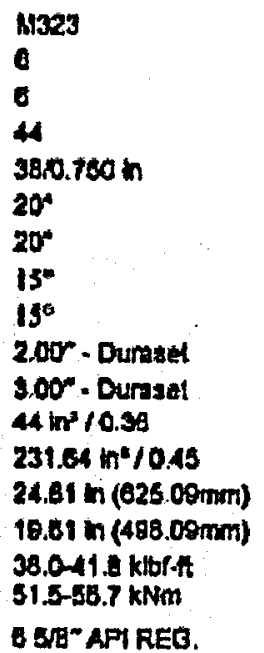

4 August 1998

\section{Qhuorise \\ Chatoninsay

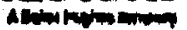

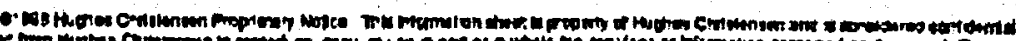

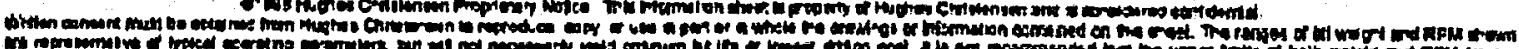

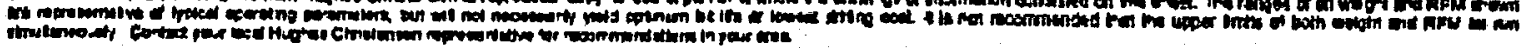

Figure 6-3. Bit Specification Sheet 
Although the AGT was designed for use with roller bits in hard crystalline rock, the turbodrill will also work well with large PDC bits because its high torque output will allow high bit weights and high penetration rates. The Baker Hughes BD536 bit is used to drill the formations in the zone were the turbodrill was to be used effectively, so this bit would provide good comparison between turbodrill and conventional drilling.

The Baker Hughes office in Reynosa provided information on the minimum flow requirements necessary to clean the PDC bit. Hughes ran several cases on their hydraulics program and determined that the minimum flow rate needed was $500 \mathrm{gpm}$. Once this value was established, it was used by MEI and Vector Oil Tools in subsequent calculations in setting up the AGT.

Since proper hydraulics is so important to the proper operation of the AGT, MEI checked with PEMEX's superintendent and engineers to verify that the Gardner Denver PZ-8 (Figure 6-4) pumps on this rig could supply the flow and pressures necessary to adequately power the AGT. PEMEX indicated that there would be no problem supplying the required flows and pressures with this rig. Based on information gathered in the pre-field test trip, it was determined that the field test could proceed.

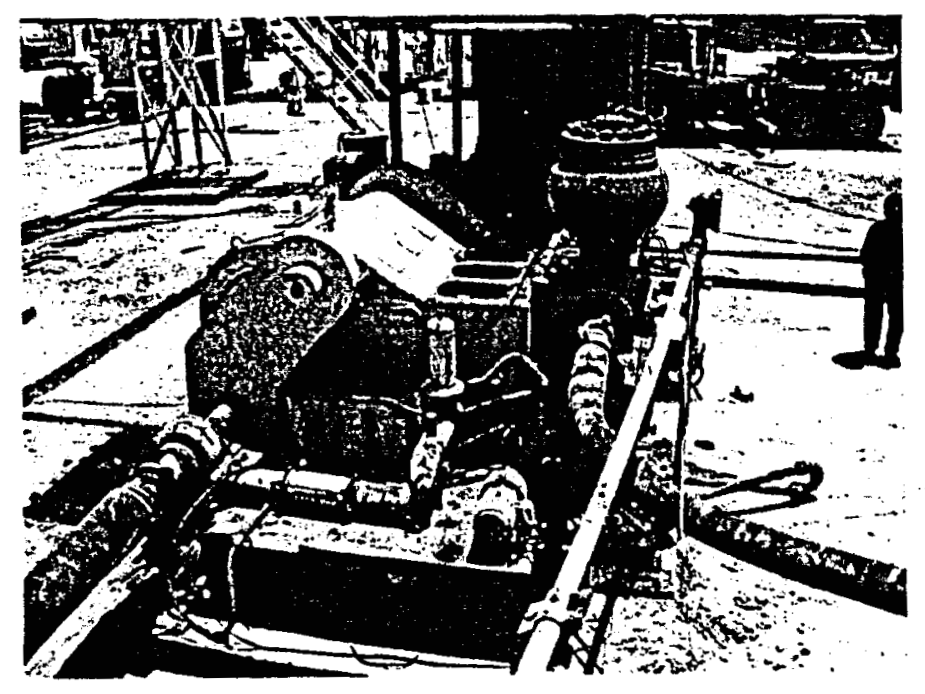

Figure 6-4. Gardner Denver PZ-8 Pump 


\section{Field Test}

\section{Summary}

Under a cooperative agreement, Maurer Engineering Inc. (MEI) and PEMEX conducted a field test of the new advanced turbodrill that Maurer developed for the United States Department of Energy. On September 9 to 14, 1999, PEMEX provided their well ARCOS 511 for testing the AGT. This well is located at the border between Mexico and the United States near Falcon Reservoir 70 miles west of Reynosa, Mexico (Figure 7-1). This field test allowed PEMEX to evaluate the performance of the turbodrill and to determine what additional training PEMEX crews would require to use this new tool. This project provided the AGT at no cost to PEMEX along with field personnel to help conduct the test.

The AGT drilled from a depth of 526 to $3940 \mathrm{ft}$ using a 121/4- inch Baker Hughes PDC bit. Flow rates during drilling were $500 \mathrm{gpm}$ and stand pipe pressures were 2,800 to 3,500 psi. The AGT drilled at rates up to $207 \mathrm{ft} / \mathrm{hr}$ compared to $76 \mathrm{ft} / \mathrm{hr}$ achieved by rotary drilling in offset wells. This is a 2- to 3-fold increase in drilling rate. Drilling was in a sandy shale formation and a 10- to 12-ppg oil-based mud w.as used to prevent reaction of the drilling fluid with the shale.

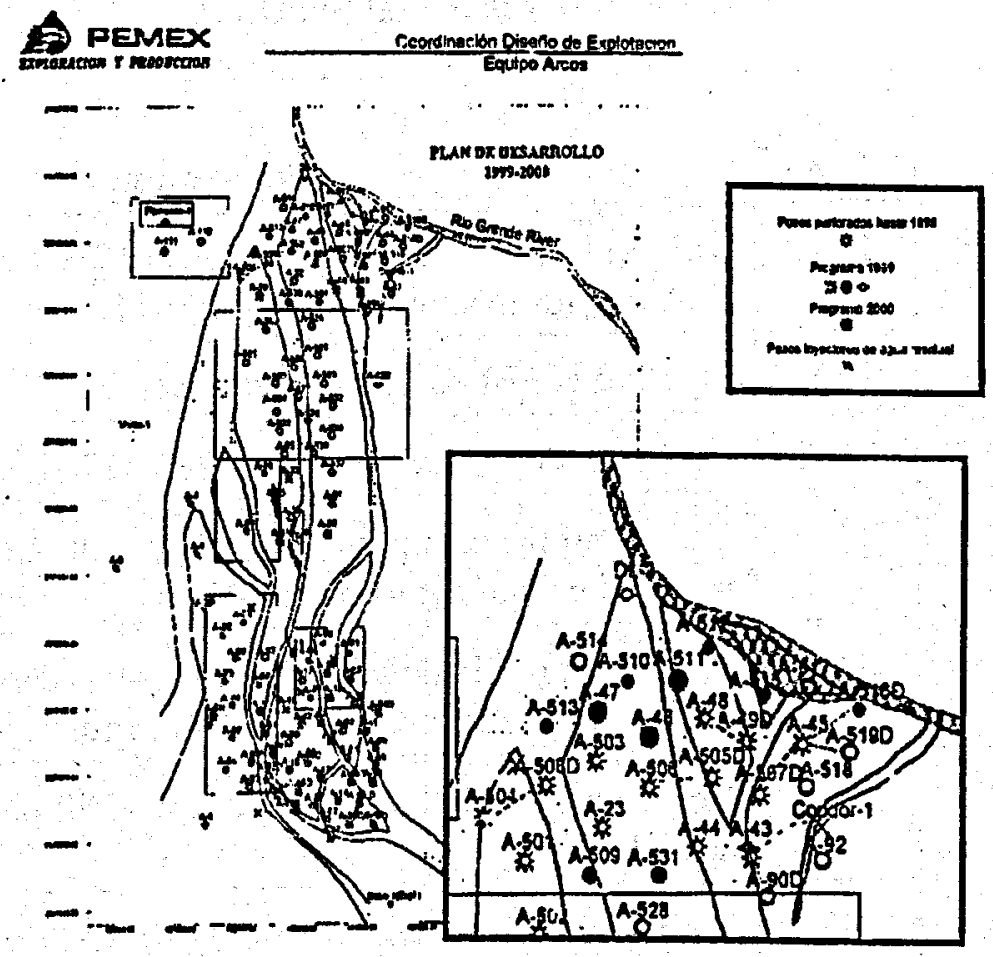

Figure 7-1. Location of PEMEX Wells 
The rig crews and drillers were able to use the turbodrill with minimal instruction. Rigging up the turbodrill into the BHA was not a problem and required no more time than rigging up conventional mud motors. Drilling operations using the AGT went very smoothly. The drillers performed their duties as normal, making no special allowances for the turbodrill being in the drill string.

Higher than expected loads on the upper seal of the gear box resulted in the failure of a friction thrust bearing after drilling 1224 feet. This led to a seal failure, which caused the turbodrill to lock up during the test. Rotary drilling was then used to finish drilling to the next casing point with the turbodrill remaining in the drill string. Following the test, the upper gear box seal was modified by replacing the friction thrust bearing with a roller thrust bearing successfully used by Vector in positive-displacement motor gear boxes. The new roller bearing will support the loads in the face seal and eliminate the problems seen on this test.

\section{Field Test Sequence}

Table 7-1 is a schedule of major field test events (data recorded during the test are presented in Appendix C).

TABLE 7-1. Field Test Schedule

\begin{tabular}{|c|c|c|l|}
\hline $\begin{array}{c}\text { Item } \\
\text { No. }\end{array}$ & Date & Time & \multicolumn{1}{|c|}{ Description } \\
\hline 1 & $10 / 8 / 99$ & 1200 & $\begin{array}{l}\text { MEI and Vector personnel arrive at PEMEX headquarters in } \\
\text { Reynosa for meeting on ARCOS 511. }\end{array}$ \\
\hline 2 & $10 / 8 / 99$ & 1600 & Meeting at PEMEX headquarters ends. \\
\hline 3 & $10 / 9 / 99$ & 0100 & MEI and Vector arrive on ARCOS 511 site. \\
\hline 4 & $10 / 9 / 99$ & 0200 & $\begin{array}{l}\text { Turbodrill picked up into derrick and bit attached. Flow } \\
\text { meter is installed into rig flow lines. }\end{array}$ \\
\hline 5 & $10 / 9 / 99$ & 0230 & $\begin{array}{l}\text { Turbodrill is laid down to install by-pass nozzle required due } \\
\text { to last minute change in well flow requirement. }\end{array}$ \\
\hline 6 & $10 / 9 / 99$ & 0330 & $\begin{array}{l}\text { Nozzle installation completed; turbodrill picked up into } \\
\text { derrick again. }\end{array}$ \\
\hline 7 & $10 / 9 / 99$ & 0430 & $\begin{array}{l}\text { Turbodrill bottom hole assembly (BHA) rig up completed. } \\
\text { PEMEX crew continues to rig up flow meter. Start running } \\
\text { turbodrill into hole. }\end{array}$ \\
\hline
\end{tabular}




\begin{tabular}{|c|c|c|l|}
\hline $\begin{array}{c}\text { Item } \\
\text { No. }\end{array}$ & Date & Time & \multicolumn{1}{|c|}{ Description } \\
\hline 8 & $10 / 9 / 99$ & 1150 & $\begin{array}{l}\text { Start drilling with turbodrill. Drill out cement above casing } \\
\text { shoe. }\end{array}$ \\
\hline 9 & $10 / 9 / 99$ & 1239 & Drill casing shoe. \\
\hline 10 & $10 / 9 / 99$ & 1250 & Pick up first full joint after drilling out casing shoe. \\
\hline 11 & $10 / 9 / 99$ & 1321 & Drill formation at very high rates. \\
\hline 12 & $10 / 10 / 99$ & 0930 & Drill rate slows. \\
\hline 13 & $10 / 13 / 99$ & 0743 & Complete drilled section. \\
\hline 14 & $10 / 13 / 99$ & 1206 & POOH. \\
\hline 15 & $10 / 14 / 99$ & 0100 & Lay turbodrill down. \\
\hline
\end{tabular}

\section{Bottom-Hole Assembly}

The field test was conducted in PEMEX's well ARCOS 511 using rig 316 (Figure 7-2). The well was rotary drilled to a depth of $512 \mathrm{ft}$, and 13\%-inch casing was set and cemented into place prior to initiation of the turbodrill test. The AGT test was begun at this point, drilling out from the casing. Figures 7-3 and 7-4 show the bottom-hole assembly containing the AGT, and Table 7-2 lists specifications of each component.

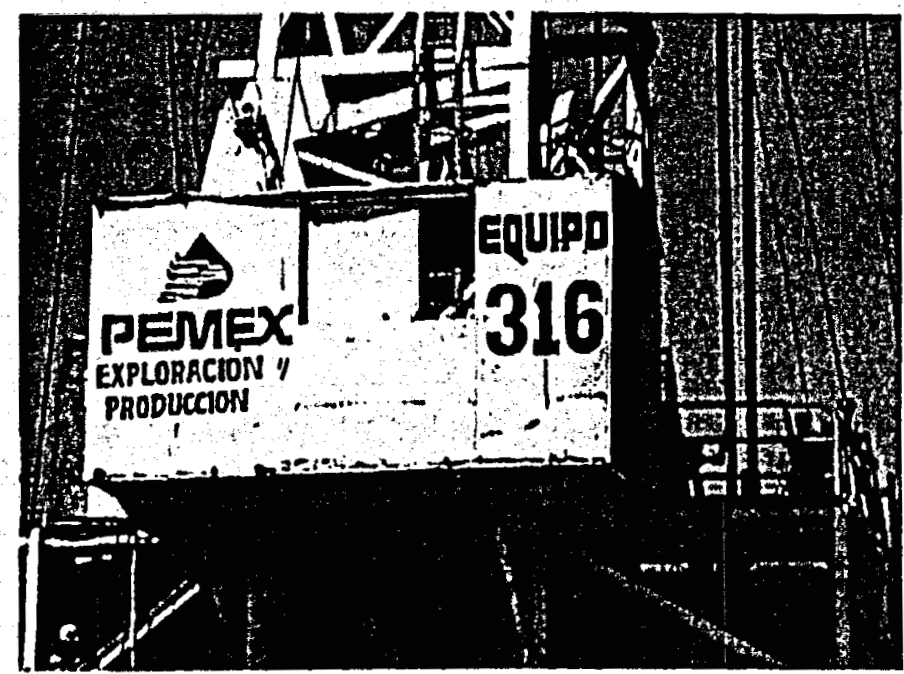

Figure 7-2. PEMEX Rig 316 


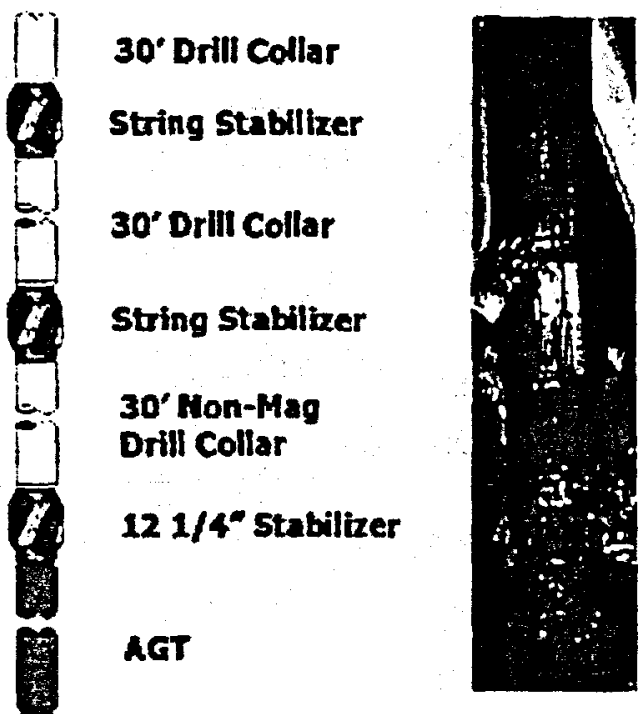

Bit

Figure 7-3. Bottom-Hole Assembly

TABLE 7-2. Bottom-Hole Assembly

\begin{tabular}{|c|c|c|}
\hline Quantity & $\begin{array}{l}\text { Length } \\
\text { (ft) }\end{array}$ & Description \\
\hline 1 & 1.3 & $\begin{array}{l}\text { 121/4" Baker AG445G Bit, 3, } 11 / 32 \\
\text { nozzles and } 3,12 / 32 \text { nozzles }\end{array}$ \\
\hline 1 & 24.8 & 95/8" Advanced Turbodrill \\
\hline 1 & 5.6 & Stabilizer 8" $\times 121 / 4 ", I D=27 / 8 "$ \\
\hline 1 & 14.5 & 8" Short Drill Collar, ID $=2^{13} / 1{ }^{\prime \prime}$ \\
\hline 1 & 5.6 & Stabilizer $8 "$ " $121 / 4 "$ \\
\hline 1 & 28.2 & 8" Drill Collar \\
\hline 1 & 5.1 & Stabilizer 8" x 121/4" \\
\hline 5 & 138.8 & 8" Drill Collars \\
\hline 1 & 1.5 & 65/8" Reg x 4" IF Cross Over \\
\hline 3 & 90.2 & 61/2" Drill Collars \\
\hline \multirow[t]{2}{*}{15} & 449.5 & Heavy Weight Drill Pipe \\
\hline & & 41/2" Drill Pipe \\
\hline
\end{tabular}




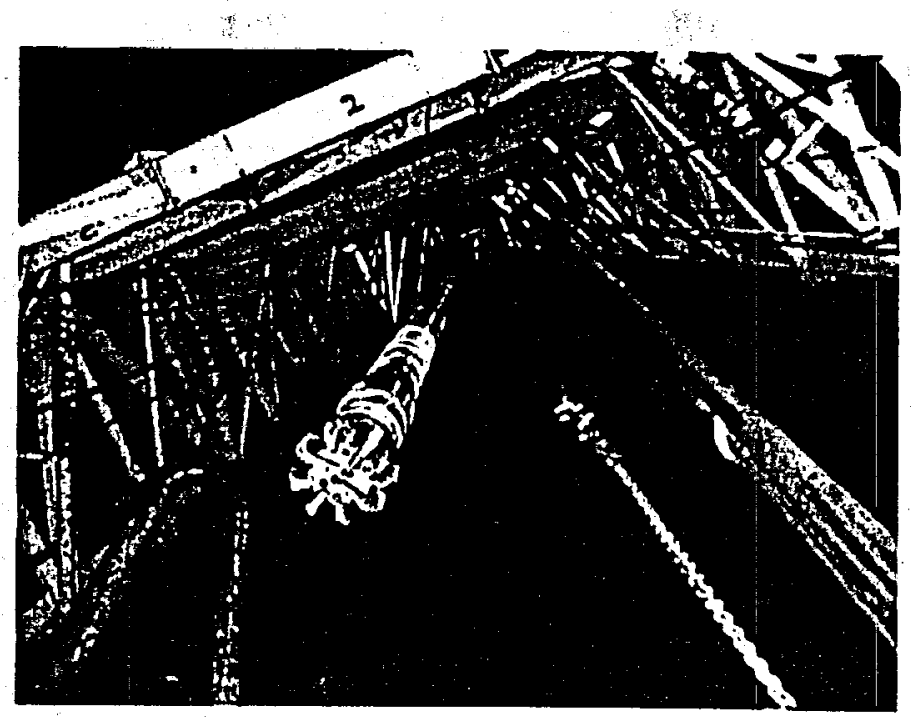

Figure 7-4. AGT Before Entering Well

PEMEX was very concerned about hole deviation since a second well was to be drilled next to ARCOS 511. To keep the hole from deviating, three stabilizers were placed in the BHA, requiring that the drill string be rotated to keep from sticking. Drill pipe rotary speed $(100 \mathrm{rpm})$ adds to the turbodrill's 80 to $120 \mathrm{rpm}$ so the combined rotary speed (180 to $220 \mathrm{rpm}$ total) coupled with the high motor torque resulted in high power output and high penetration rates.

\section{Drilling Results}

The AGT drilled from a depth of 526 to $1750 \mathrm{ft}$ at rates of 111 to $207 \mathrm{ft} / \mathrm{hr}$ compared to 76 $\mathrm{ft} / \mathrm{hr}$ rotary drilling in offset wells (Figure 7-5). At $1750 \mathrm{ft}$, the data indicated that the turbodrill had locked up, and rotary drilling was conducted with the turbodrill in the drill string from 1750 to 3850 $\mathrm{ft}$ with penetration rates essentially identical to rotary drilling rates in offset wells at corresponding depths (i.e., 45 vs. $48 \mathrm{ft} / \mathrm{hr}$ ).

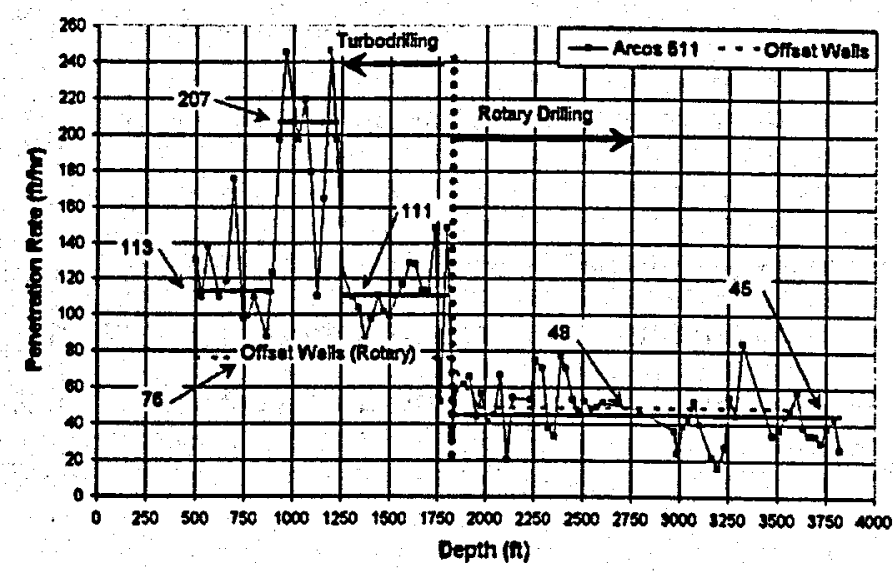

Figure 7-5. ARCOS 511 Penetration Rate 
The failure of the AGT was not easily detected for two reasons. First, the turbodrill was being run at $100 \mathrm{rpm}$ on the rotary table. Had there been no drill string rotation, drilling rate would have dropped to zero, a clear indication of motor failure. Second, the failure occurred simultaneously with a change in formation characteristics, where slower drilling rates were expected. This formation change can be seen from conventional drilling rates in offset wells which typically drop from 76 to $48 \mathrm{ft} / \mathrm{hr}$.

Problems detecting AGT failure can be avoided in the future by periodically locking the rotary table and drilling solely with the turbodrill. If the AGT is not functioning properly, there will be no penetration, and a decision can be made to continue rotary drilling or to pull out of the hole and replace the turbodrill. This periodic test procedure will be adopted on future AGT tests. This procedure is necessary because, unlike Moineau motors, there is not a significant rise in pressure when a turbine stalls.

Figure 7.6 shows that from 500 to $929 \mathrm{ft}$ (Interval 1), the AGT drilled at $113 \mathrm{ft} / \mathrm{hr}$ compared to $76 \mathrm{ft} / \mathrm{hr}$ for rotary drilling in offset wells. Pump pressure was increased from 700 to $2800 \mathrm{psi}$ and bit weight was varied from 3,000 to $11,000 \mathrm{lbs}$ in this interval.

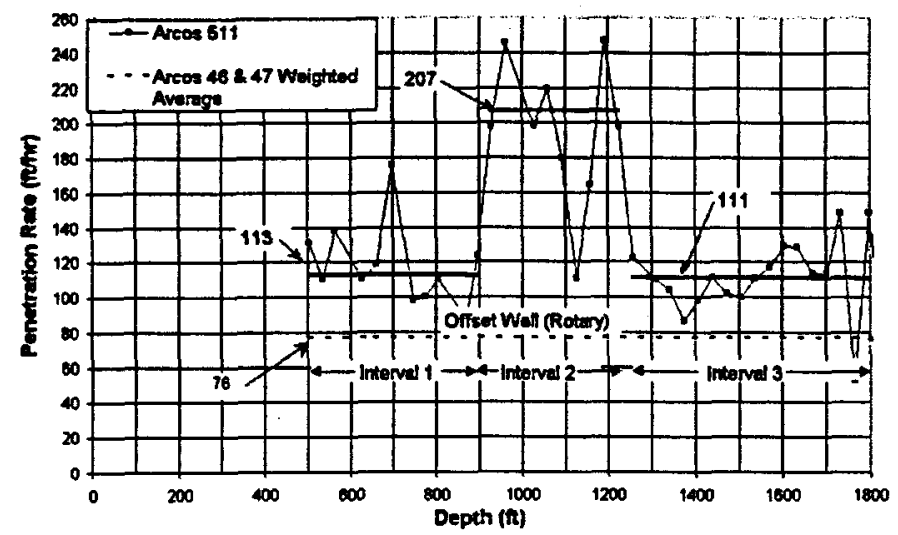

Figure 7-6. Advanced Geothermal Turbodrill ROP

During much of the test, pump pressure was limited to $2,800 \mathrm{psi}$, which limited drilling rates. PEMEX was concerned that running for extended periods above 2,800 psi would cause the rig swivel packing to fail, resulting in lost time to repair the swivel. Interval 2 (929 to 1,257 ft), pump pressure was increased from 2,800 to 3,500 psi (Figure 7-7), allowing higher bit weights and higher drilling rates. 


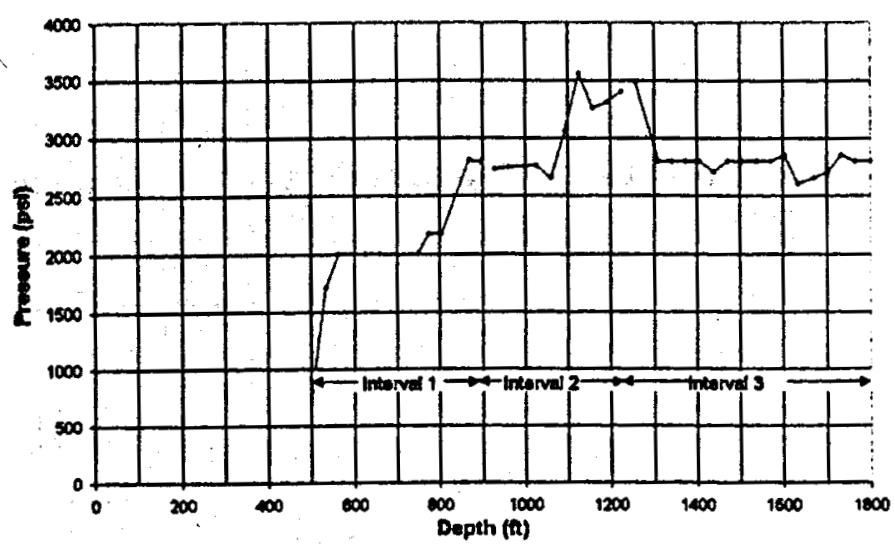

Figure 7-7. Stand Pipe Pressure

From Interval 1 to Interval 2, bit weight was increased from 10,500 to 18,000 lbs (Figure 7-8), which increased the torque from 4,800 to $6,000 \mathrm{ft}-\mathrm{lbs}$ (Figure 7-9) and the standpipe pressure from 2,800 to 3,500 psi. The drilling rate increased from $113 \mathrm{ft} / \mathrm{hr}$ in Interval 1 to $207 \mathrm{ft} / \mathrm{hr}$ in Interval 2. Flow rate was held nearly constant at $520 \mathrm{gpm}$ over this interval (Figure 7-10). Data from Interval 2 show that the turbodrill can drill two to three times faster than rotary drilling when operated at peak power output. It is important to have high-capacity rig pumps and sufficient drill collars to fully utilize the high-power capabilities of the turbodrill.

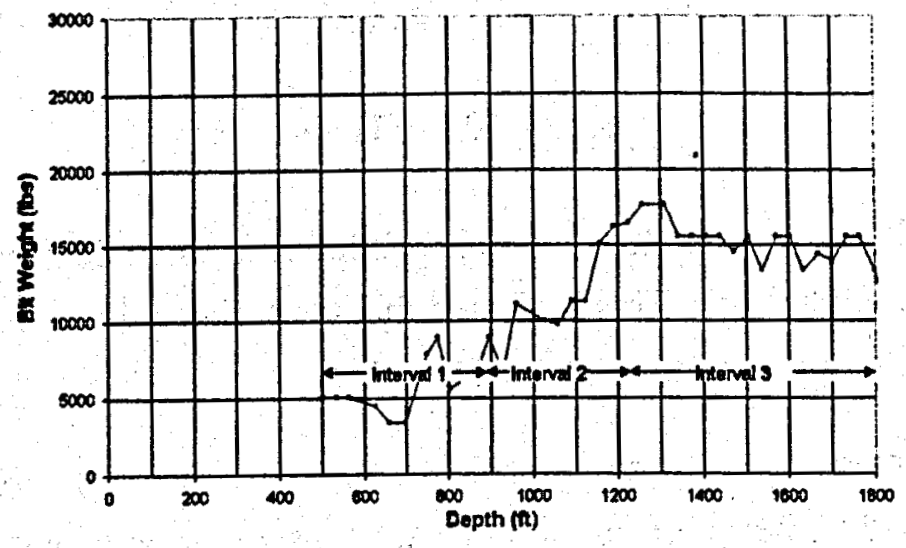

Figure 7-8. Weight-On-Bit 


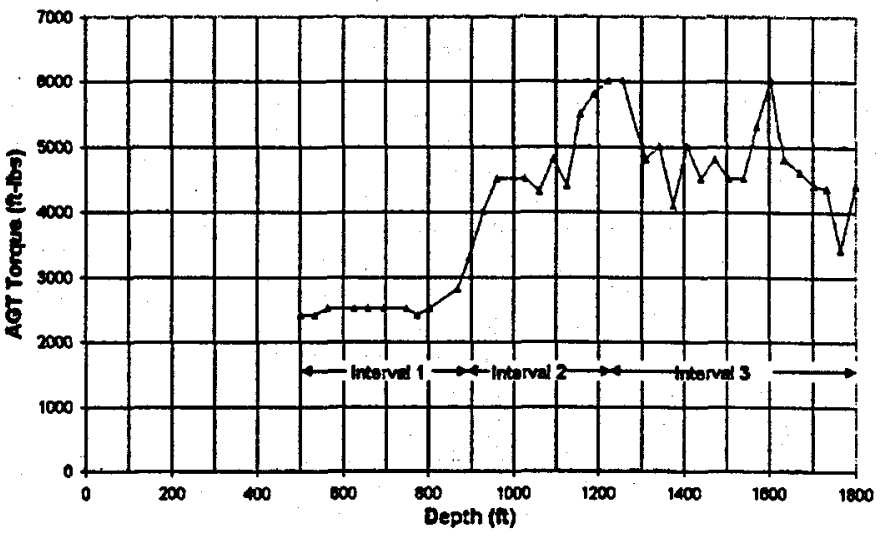

Figure 7-9. AGT Torque

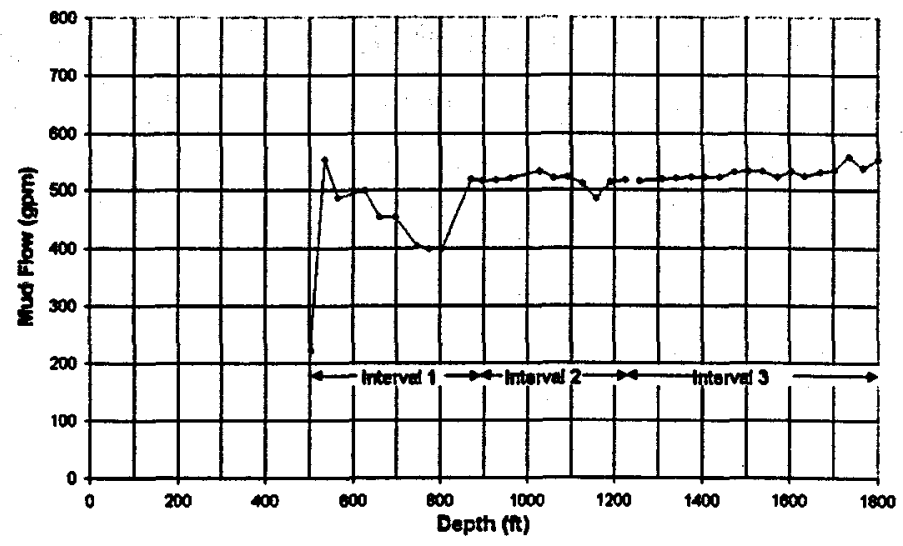

Figure 7-10. AGT Flow Rate

In Interval $3(1,257$ to $1,840 \mathrm{ft}$, WOB was lowered to $16,000 \mathrm{lbs}$, causing a reduction in standpipe pressure to $2,800 \mathrm{psi}$. This indicated that the turbodrill was producing less power and resulted in a reduction in penetration rate to $111 \mathrm{ft} / \mathrm{hr}$.

Cuttings samples taken from the shale shaker (Figure 7-11) show that the PDC bit was drilling very efficiently when high bit weights were used. In areas where WOB was reduced, cuttings were much smaller and penetration rates slower. 


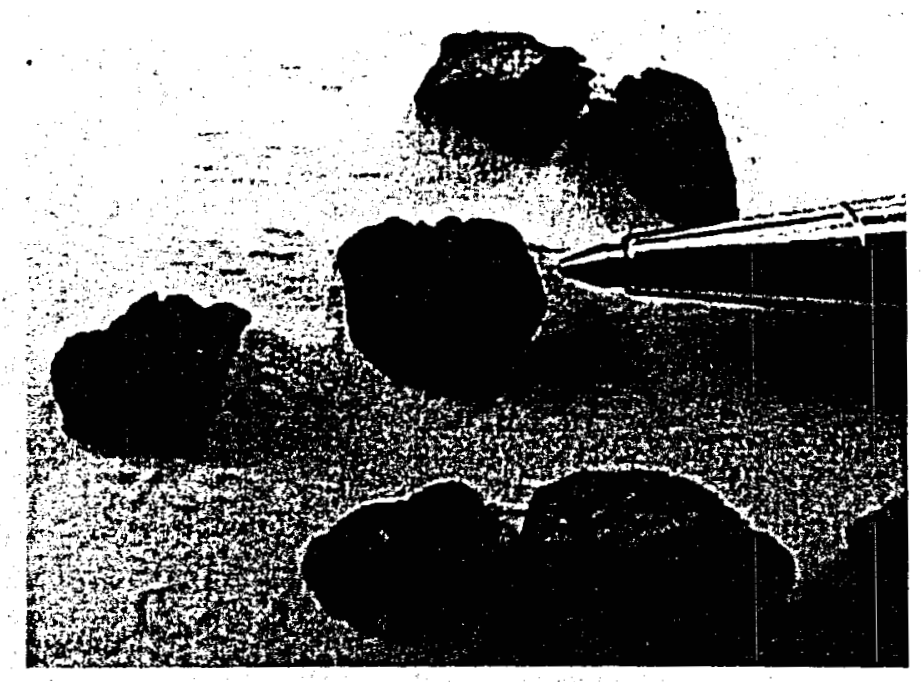

Figure 7-11. Large Drill Cuttings

\section{Rig Operations}

The AGT presented no difficulties for the rig crew in the makeup or breakout of the BHA. In this test, total time to make up the BHA was 2 hours 30 minutes, including 1 hour to install a bypass nozzle in the turbodrill. A last minute change in the bit flow requirement from 500 to $550 \mathrm{gpm}$ made it necessary to install a by-pass nozzle in the turbodrill rotor. Installing the nozzle required that the turbodrill be laid down, which took extra time and could have been avoided had correct flow requirements been supplied prior to the test. If this delay is excluded, makeup of the BHA was only 1 hour 20 minutes.

\section{Instrumentation}

MEI arranged for a TOTCO data acquisition system to be installed on this rig to aid in collection of drilling data and operation of the AGT. In addition, MEI supplied a Halliburton turbine flow meter so that mud flow to the turbodrill would be measured accurately (Figure 7-12). 


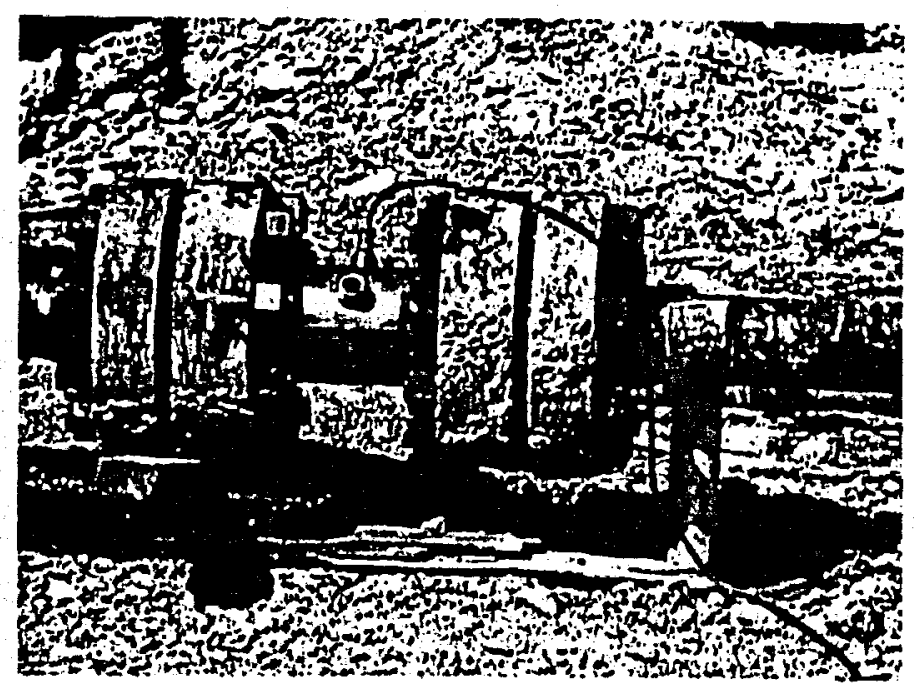

Figure 7-12. Halliburton Turbine Flow Meter

Early in the test there was a discrepancy between measured and calculated flow based on pump strokes. It was discovered that one of the pumps was stroking but was not flowing due to seal leakage in the pump. The flow meter allowed this problem to be diagnosed quickly and repairs made early in the test. Had this not been done, considerable time might have been wasted drilling at low flow rates. This experience showed that a direct measurement of flow is beneficial for the AGT.

The TOTCO data system was disappointing because it broke down several times during the test, and calibration of most measurements was incorrect. As a consequence, very little useful data were obtained. Figure 7-13 shows the TOTCO output screen.

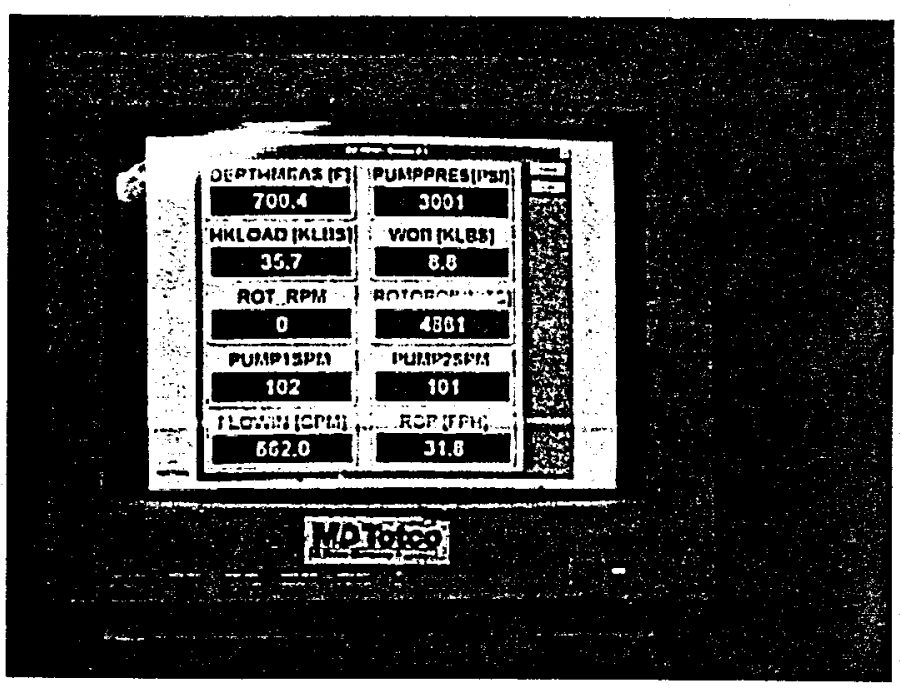

Figure 7-13. TOTCO Output Screen 
The most useful data gathered from the TOTCO system was rotary table torque, which was a good measure of the drilling quality. High torques indicated maximum penetration rates. Low torques occurred when the bit was only skimming the surface of the formation and drilling slowly. Rotary table torque was easy to collect on this rig since it was diesel electric and torque can be determined from the current used to drive the motor that turns the rotary table. If torque cannot be measured directly from the rotary table or a top drive, a torque sub should be considered for the AGT. 


\section{Turbodrill Post-Test Inspection}

\section{Gear Box Failure}

After the field test, the turbodrill was sent to Vector Oil Tool for disassembly to determine why the gear box had locked up. Disassembly showed that the gear box upper seal and thrust bearing had failed, resulting in lock-up. It was further determined that lock-up must have occurred very quickly after seal failure. The gear box was full of fines from the drill mud that were so invasive that many of the gear box components had to be pressed apart during disassembly. Despite the quantity of abrasives in the gear box, the gears themselves showed no wear. Figure 8-1 shows one of the planetary gears after it was removed from the turbodrill and cleaned. There are no signs of wear on the gear teeth.

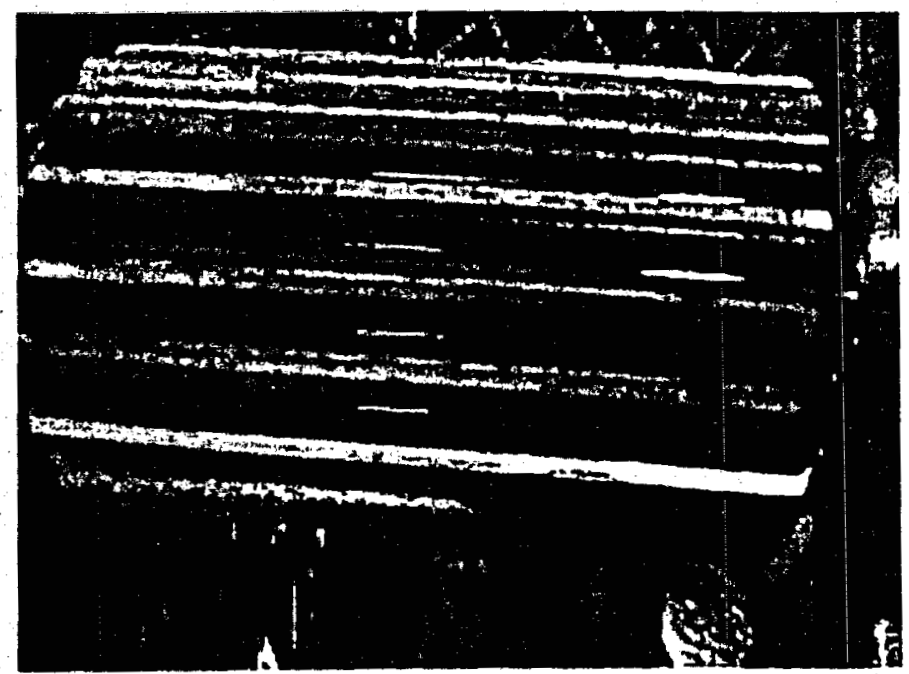

Figure 8-1. Planetary Gear after Disassembly

If the turbodrill had run for a long period after the seal failed, the gears would have shown wear from the abrasive fines. This sample is representative of the other parts in the gear box. Figure 8-2 shows the planetary gear before it was cleaned; fines from the mud can be seen on the gear. 


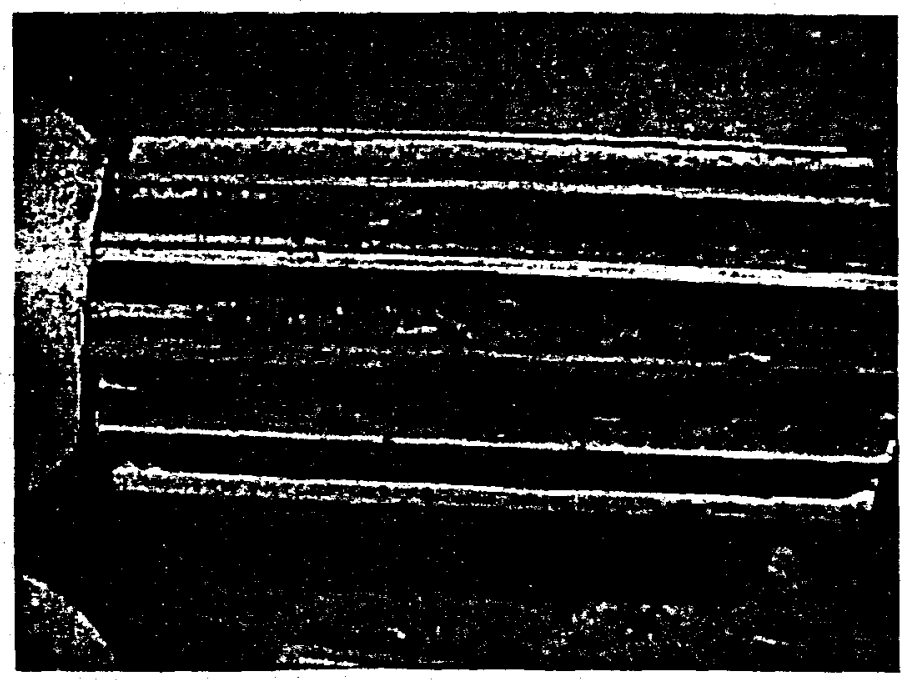

Figure 8-2. Planetary Gear with Drill Fines

After all parts in the gear box were examined, the following scenario was developed to explain the failure. The AGT uses a proprietary pressure-balance system to keep oil pressure in the gear box at a higher level than the mud pressure acting on the outside of the gear box. In this way, oil leaking past the seal lubricates the faces and keeps mud out of the gear box. However, this pressure difference places a hydraulic load on the seal faces as shown in Figure 8-3, a schematic of

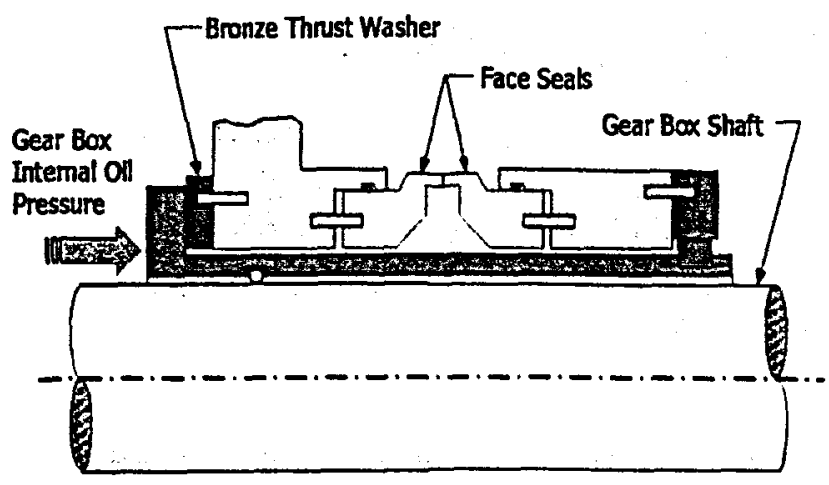

Figure 8-3. Upper Gear Reducer Seal

the upper gear seal reducer. In the current design, an aluminum/bronze thrust washer (Figure 8-4) is used to absorb this load. It was determined that these loads became too high for the thrust washer, causing it to heat, extrude, and block fresh oil from the face seal. Figure 8-5 shows the thrust washer removed from the turbodrill run in ARCOS 511. The extruded collar and severe wear on the 
underside indicate that this part was severely over loaded. The extruded section covered an oil port, which prevented oil from reaching the seal face and caused it to overheat.

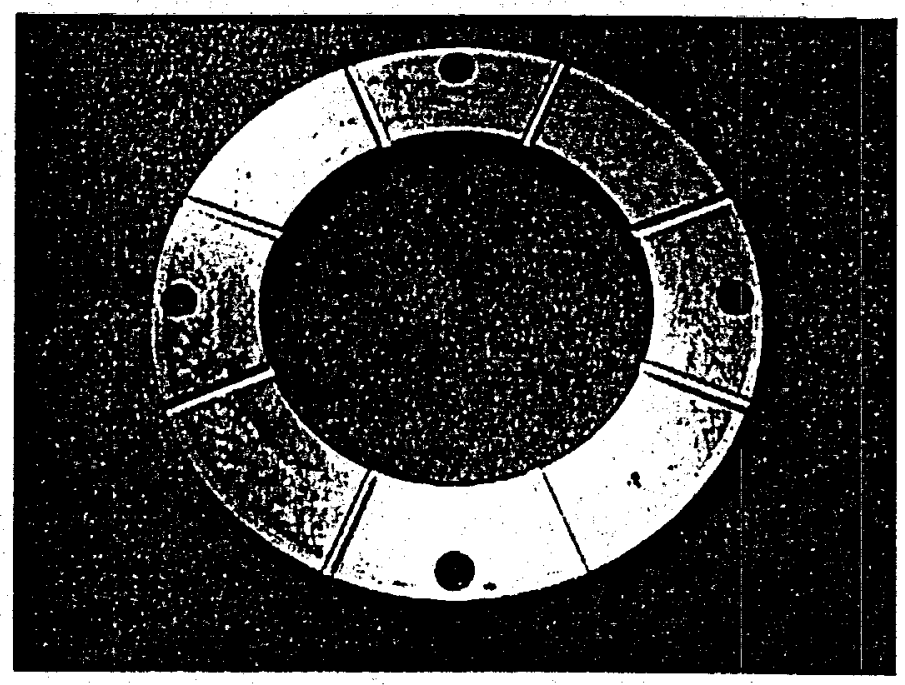

Figure 8-4. Aluminum/Bronze Thrust Washer

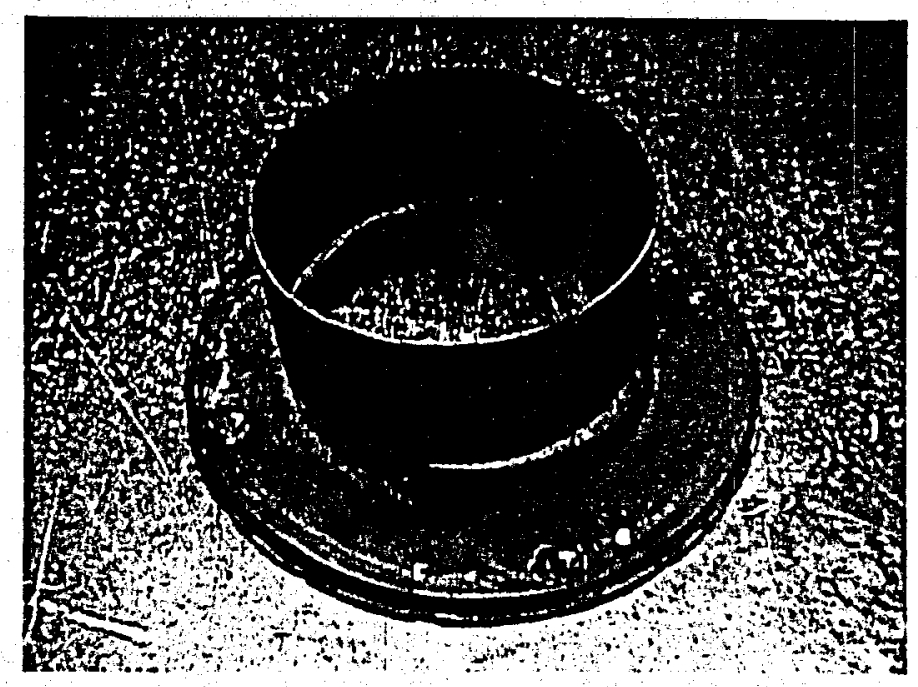

Figure 8-5. Extruded Thrust Washer

Figure 8-6 shows half of a good face seal, while Figure 8-7 shows the broken upper face seal removed from the ARCOS 511 turbodrill. Close examination of the broken face seal shows severe heat checking (Figure 8-8), indicating that these parts became very hot due to friction. This is further evidence that the seal was deprived of oil and allowed to overheat. 


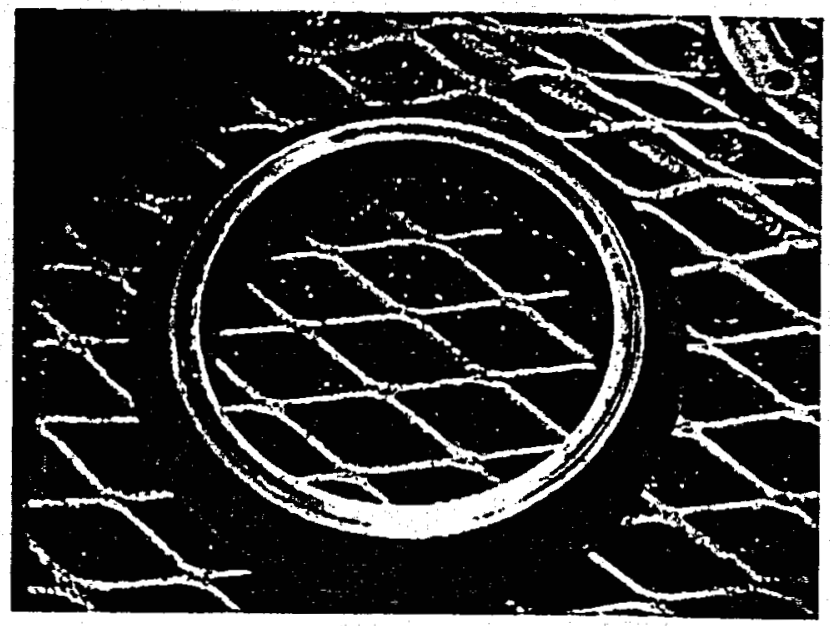

Figure 8-6. Good Face Seal

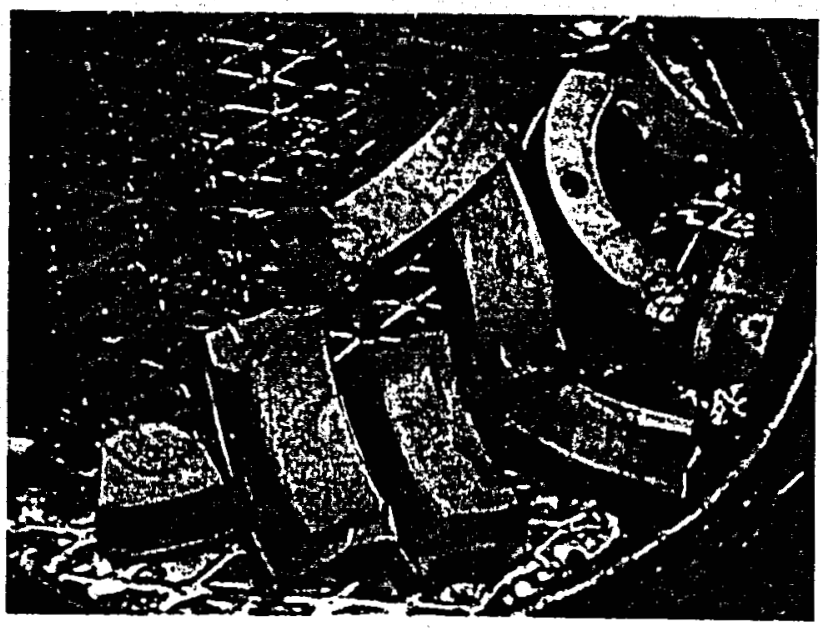

Figure 8-7. Broken Face Seal

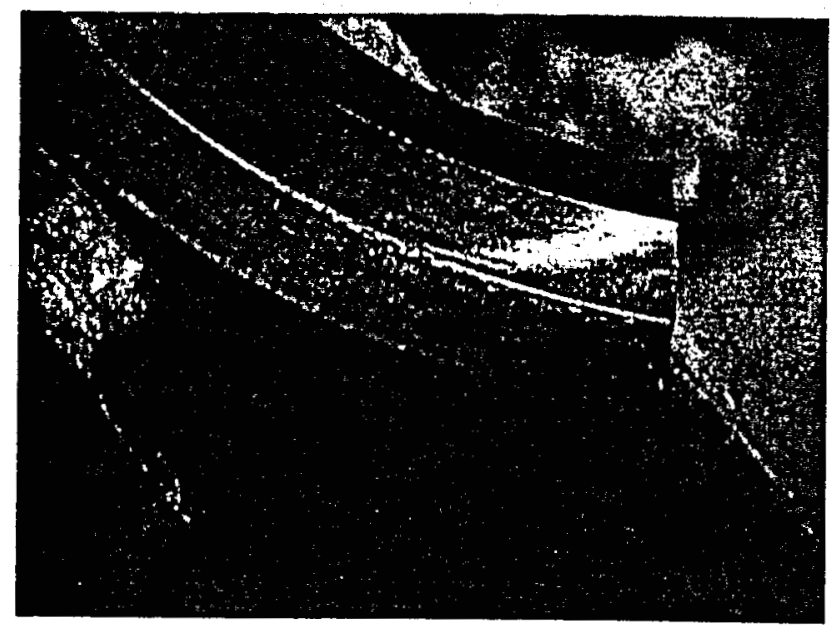

Figure 8-8. Heat Checking on Face Seal . 
After the seal failed, oil in the gear box leaked out and allowed mud to enter. The uppermost thrust bearing is under the highest loading in the gear box. It must absorb all the down thrust from the turbine shaft while operating at speeds up to $2,500 \mathrm{rpm}$. In the presence of drill mud, this bearing failed and seized to the shaft, causing the turbodrill to lock up. Figure 8-9 shows the first stage of the gear box with the seized thrust bearing. This bearing ultimately had to be machined off the shaft (Figure 8-10).

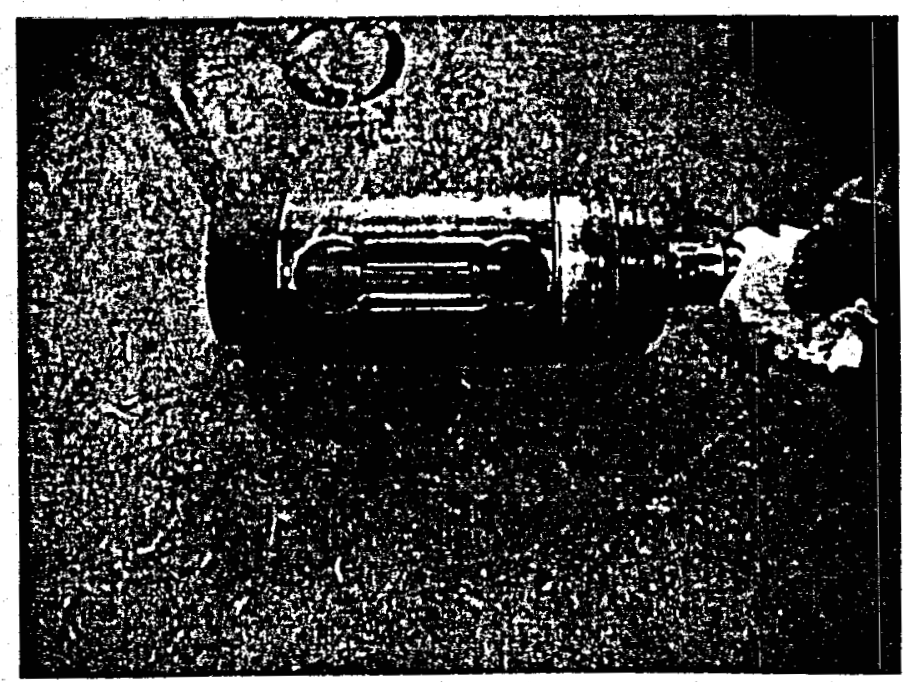

Figure 8-9. Gear Box Upper Stage

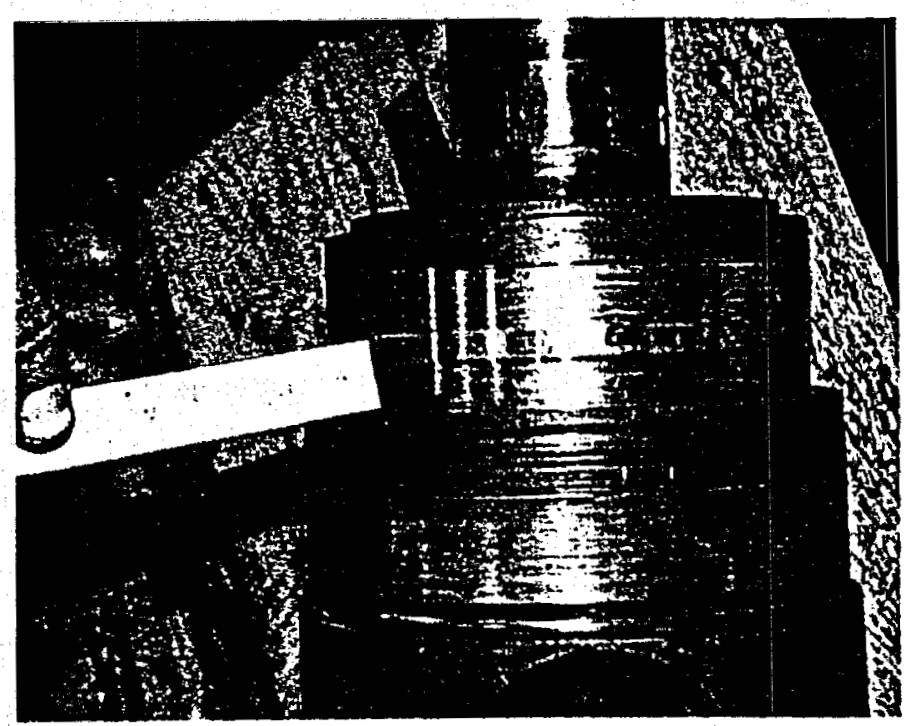

Figure 8-10. Seized Thrust Bearing 


\section{Seal Redesign}

To prevent future failures, the thrust washer that failed on the seal assembly has been replaced with a roller thrust bearing. This new bearing can operate at much higher loads than the thrust washer. Figure 8-11 shows the roller thrust bearing mounted in the gear box housing. With adequate oil, the upper face seal will stay cool and not fail. As long as oil remains in the gear box, all components, including the upper thrust bearing, will have long lives.

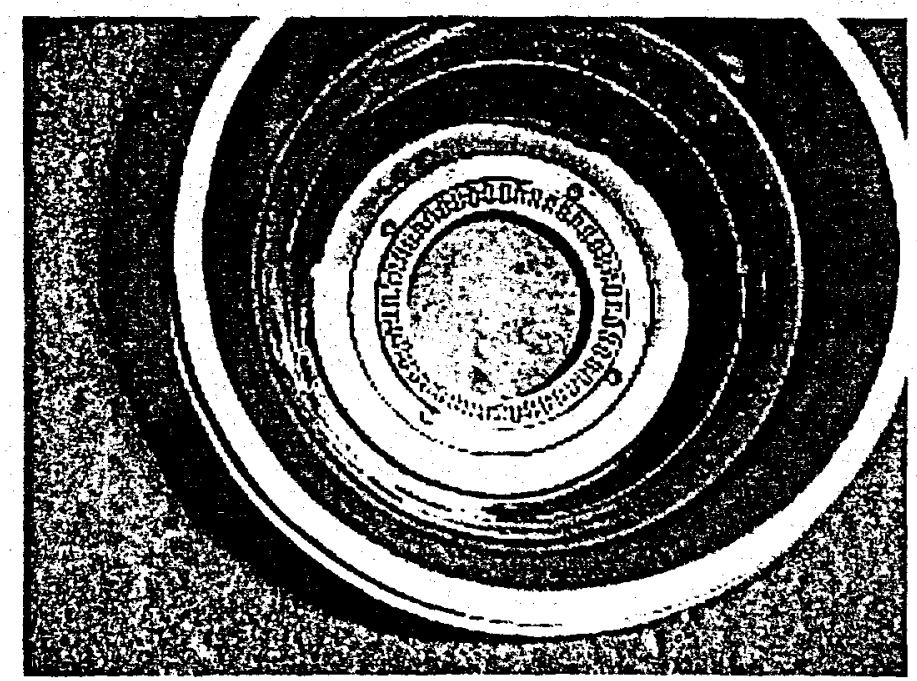

Figure 8-11. New Roller Thrust Bearing

\section{Turbine Blades}

The LANL turbodrill blades were manufactured for use in clear water or light geothermal muds. The stators were made from beryllium copper and the rotors from 17-4 PH stainless steel. The blades had long life during the Fenton Hill drilling. However, the ARCOS 511 well was drilled with a heavy oil-based mud (10 to $12 \mathrm{ppg}$ ) with a high solids content. This test presented a challenge for the AGT blading and an opportunity to determine the best materials and designs for this environment. The high solids content of the mud caused severe erosion on both the stators and rotors. It is not known if this erosion would have been more or less had the AGT not locked up. The beryllium copper stators wore much more that the 17-4 PH stainless steel rotors. This is very unexpected since the stator hardness is several points higher than the rotor (stator hardness is 46 to $50 \mathrm{Rc}$ while the rotor hardness is 40 to $45 \mathrm{Rc}$ ). Figure 8-12 shows a typical rotor removed from the AGT after the ARCOS 511 test. Although clearly worn, this part could continue to operate. 


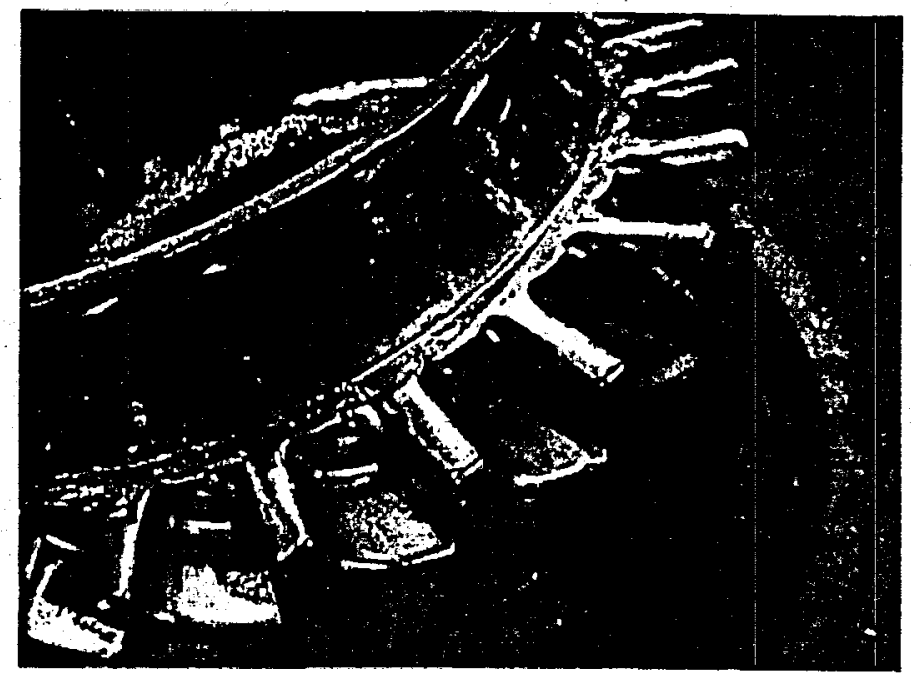

Figure 8-12. Worn Stator

Figure 8-13 shows a worn stator from the AGT where the blades have.separated from the outside ring. In addition, holes worn in the outside ring caused pits to be worn into the housing (Figure 8-14). Much of this erosion probably occurred after the gear box unit locked up and prevented the rotary blades from rotating.

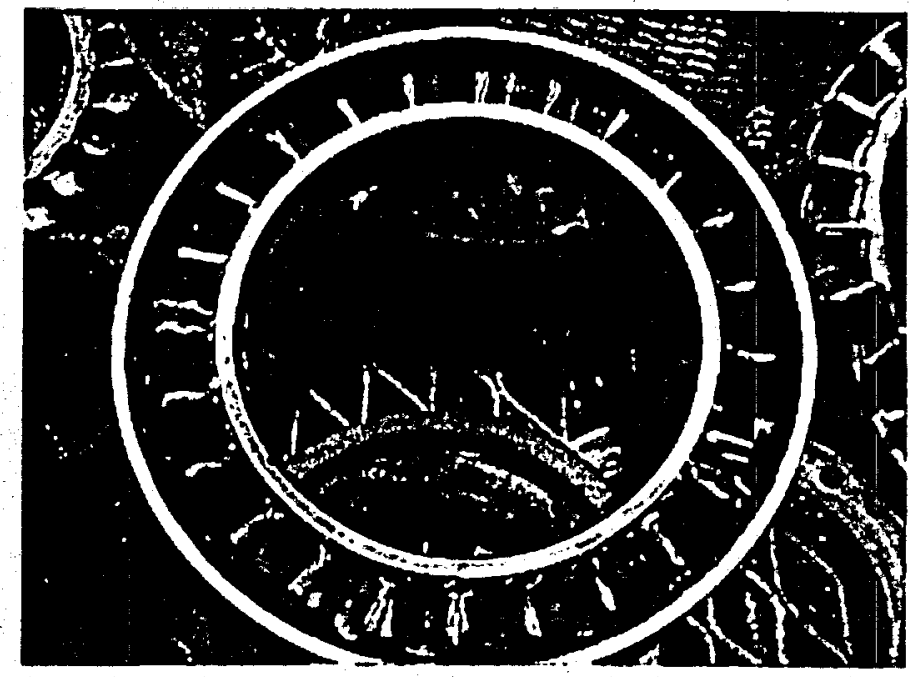

Figure 8-13. Worn Stator 


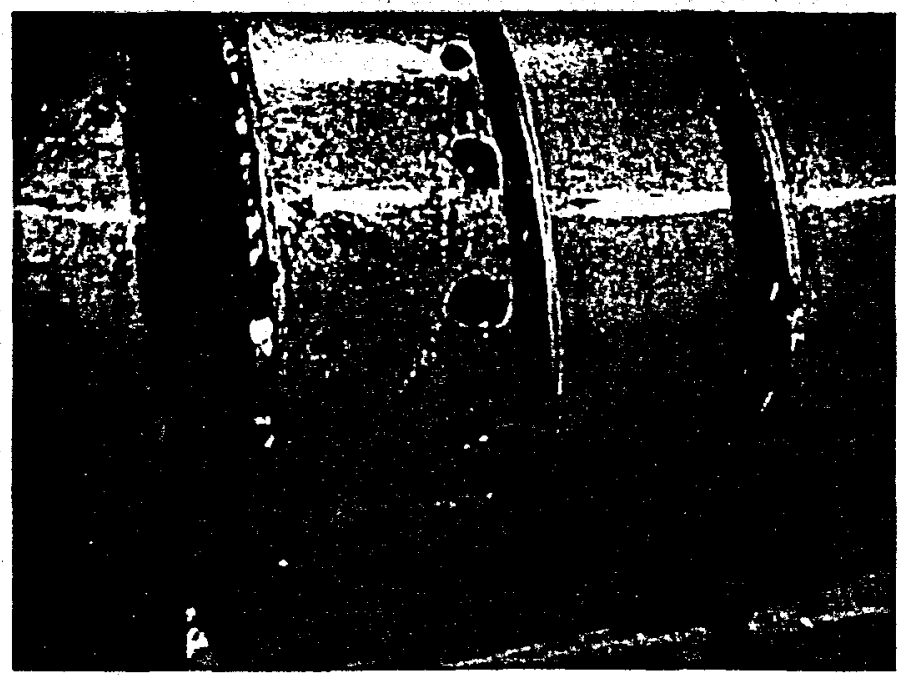

Figure 8-14. Hole in Stator Ring

These data show that, while the LANL blades will work for geothermal drilling fluids, when fluids with high solids content are to be used, both the rotor and stator need to be made from 17-4 PH stainless steel or some other wear-resistant material. 


\section{Conclusions}

The following conclusions were reached as a result of this study.

1. The Advanced Geothermal Turbodrill (AGT) was shown to produce the high torques and low speeds required to effectively drill geothermal rocks at high rates.

2. In laboratory tests the AGT drilled 121/4-inch holes in granite at $90 \mathrm{ft} / \mathrm{hr}$.

3. In a PEMEX field well, the AGT drilled at rates up to $207 \mathrm{ft} / \mathrm{hr}$ compared to 76 $\mathrm{ft} / \mathrm{hr}$ for rotary drills.

4. The turbodrill performed well during the PEMEX field tests and the drillers found it very easy to run.

5. After drilling $757 \mathrm{ft}$ in the PEMEX well (500 to $1257 \mathrm{ft} \mathrm{MD),} \mathrm{a} \mathrm{thrust} \mathrm{bearing}$ failure in the speed reducer caused the turbodrill to lock up.

6. Replacement of the friction thrust bearing with a roller thrust bearing will eliminate this problem on future tests.

7. The AGT has the potential to drill 1000 - to 2000 -ft horizontal wells in geothermal formations to intersect more fractures and increase well production 3- to 5-fold.

8. The AGT should be tested as soon as possible in the hot section of a geothermal well.

9. The Mexican geothermal company, Comision Federal Electricidad (CFE), has agreed to test the AGT in one of its geothermal wells on a cost-sharing DOE project. 


\section{References}

Cohen, John H., and Maurer, William C., 1999: "Laboratory Drilling Tests of Advanced Geothermal Turbodrill," ETCE99-6650, presented at the Energy Sources Technology Conference \& Exhibition, held in Houston, Texas, February 1-7.

Neudecker, J.W., and Rowley, J.C., 1982: "High-Temperature Directional Drilling Turbodrill," LA-9231-MS, UC-66c, February.

Rowley, John C., 1982: Personal Communications, Los Alamos Scientific Laboratories, Los Alamos, New Mexico. 


\section{APPENDIX A}

Contract Between PEMEX and Maurer Engineering Inc. to Test Advanced Geothermal Turbodrill 


\section{PEMEX \\ EXPLORACIÓN Y PRODUCCIÓN}

GRATUITOUS TITLE AGREEMENT TO DEVELOP THE TECHNOLOGICAL TEST ENTERED ON ONE SIDE PEMEX EXPLORACIÓN Y PRODUCCIÓN, HEREINAFTER KNOWN AS "PEP", REPRESENTED BY ING. CARLOS RASSO ZAMORA, IN HIS CAPACITY OF COMPANY, AND ON THE OTHER, MAURER ENGINEERING INC. REPRESENTED BY ING. ROBERT SAUCEDO, IN HIS CAPACITY OF LEGAL REPRESENTATIVE WITH THE POWER OF ATTORNEY OF THE SOCIETY HEREINAFTER KNOWN AS "MEI", IN ACCORDANCE WITH THE FOLLOWING DECLARATIONS AND CLAUSES:

\section{DECLARATIONS}

I.- PEP declares that:

1. It is a decentralized Public Enterprise. of the Federal Government of the United Mexican States, and a subsidiary of Petróleos Mexicanos, with separate legal status and assets and with the legal capacity to enter on this Agreement, in accordance with its Organic Law published in the Official Gazette of the Federation on July 16, 1992.

2. ING. CARLOS RASSO ZAMORA, deputy Director of the Drilling Unit and Well Maintenance, accredits his legal status in accordance with Article 12 of the above-referenced Law, which bestows upon him, the capacity of legal representative with the full power to perform administrative acts.

3. It has established its legal domicile at Boulevard Adolfo Ruiz Cortinez No.1202, $8^{\circ}$ piso, Edificio Piramide de Tabasco, C.P. 86030 , for the purposes and legal effects of this Agreement.

4. PEP, through its Well Drilling and Maintenance Deputy Direction, has as main object within their activities, the planning and performance of well 
drilling processes with the highest quality and safety within a sustentable development frame, therefore, it is necessary to be updated in everything related with the technological progress of those processes, using new materials, techniques and advanced technology systems.

\section{II.- MEl declares that:}

1. It accredits the existence of its company since Jums 10,1974

2. It is of American nationality and agrees that, whether it is foreign or, being Mexican, it changes its nationality, it shall be considered to be Mexican for the purposes of this Agreement and agrees not to invoke the protection of its government or any other foreign government, under the penalty of losing all the rights derived from this Agreement, conferred by the Mexican nation.

3. It has the legal capacity to enter into contracts and satisfies the technical and economical requirements in order to undertake the performance of the works object of this Agreement.

4. It has established its legal domicile at 2916 Western TC Jester, Houston, Texas, for the purposes and effects of this Agreement.

5. That it is familiar with the set forth Annexes, which properly signed by the parties, they are considered as an integral part of this Agreement:

ANNEX "B"

ANNEX "E"

ANNEX "E-1"
TECHNICAL SPECIFICATIONS

RESOURCES THAT SHALL BE PROVIDED BY PEP

RESOURCES THAT SHALL BE PROVIDED BY MEI

III.- That it is interested in PEP to try, at no cost at all and no further compromise, their product known as Advanced Geothermal Turbine (AGT).

1 The representatives affirm that the powers under which they are subscribing to this Agreement have not been revoked or amended in any way. 
In view of the foregoing and based on the provisions established in Article 1792 and any other applicable from the Civil Code for the Federal District, applicable for all the Mexican Republic in Federal matters, as well as the declarations mentioned and given the interest from both parties to execute this Agreement, entered on one side PEP through the Technology Management of the Well drilling and Maintenance Deputy Direction, and on the other, the Enterprise MEI, the parties execute the following:

GRATUTTOUS TITLE AGREEMIENT

NUMBER:

MAURER ENGINEERING INC.

\section{CLAUSES}

\section{FIRST.- OBJECT OF THE AGREEMENT}

MEI offers PEP and this latter accepts, under the conditions stated in this agreement and its annexes, the development of a field Technological Test with no cost, with the purpose that PEP could be able to assess the benefits and/or usage of a devise denominated "Advanced Geothermal Turbine".

According to the supplier, this "Advanced Geothermal Turbine" results in an increase of the drilling speed and a long lasting life of the motor, eliminating death times due to failures of the material or the tool mechanism. It also represents an advantage for having less changes in the motor due to failures. The said test shall be perform in a drilling equipment belonging to PEP within the Mexican Republic. It is expressly agreed by both parties, that whichever the result of the test is, there is no further compromise acquired by PEP with the company MEl.

\section{SECOND.-AGREEMENT AMOUNT.}

The Technological Test, object of this Agreement, shall be performed under MEI costs, without having the right to receive from PEP any payment for the said concept whichever the result of the test is. PEP is exclusively obliged to provide equipment, personnel and the necessary goods in order to develop the test in accordance with what has been established in Annex " $E$ " of this same Agreement. At the end of the tests, the results shall be delivered to MEI in accordance to what is stated in Annex $B$. 


\section{THIRD.- TEST EXECUTION TERM}

MEl is committed to totally develop the test object of this Agreement, in a 80 day term as a minimum of effective operation, without computing the delays due to unforeseen circumstances or force majeure. MEl is committed to star the tests in accordance with the schedule agreed with PEP. Start

\section{FOURTH.- SUPPLIER INSURANCE.}

During the performance of the test, object of this Agreement, MEI is committed to carry and maintain an insurance policy for civil responsibility in general, which shall cover damages to PEP and/or third parties, personnel, injury or property.

The minimum coverage must be the amount of $\$ 100,000.00$ USD (One hundred thousand American dollars) per event. In the intelligence that the tests, object of this Agreement, must not be executed until PEP has received from MEI a copy of the Policy or Certificate stating its issuance.

The presentation of the said Policy does not limit MEl liabilities.

\section{FIFTH.- MEI TECHNICAL REPRESENTATIVE.}

MEl is committed to assign a technical representative, Spanish speaker, and with the power to make decisions about everything related to the compliance of this Agreement.

MEI shall be responsible for the said representative to be an expertise in the matters related to this Contract.

\section{SIXTH.- LABOR}

MEl as an enterprise and employer of the staff members involved with the performance of the tests, purpose of this Agreement, shall be the 
only responsible party for the obligations arising from the legal provisions and other applicable ordinances in connection with work and social security. Therefore, MEl agrees in responding to all claims that their crew or third parties present against them or against PEP, and they shall indemnify any amount which may be generated for this concept.

\section{SEVENTH.- MEI RESPONSIBILITIES.}

MEl guarantees that the personnel, goods, tools, accessories, spare parts and in general terms, everything required for the satisfactory execution of this Agreement shall comply with the highest quality standards. Likewise, labor shall be performed in accordance with the best practices of the industry, and deal with any other responsibility occurring during the performance of the Test purpose of this Agreement.

GRATUITOUS TITLE AGREEMENT

NUMBER:

MAURER ENGINEERING INC.

MEI shall also respond for those damages or prejudices which may affect PEP or third parties, in which case, MEl shall respond in the terms of the Civil Code for the Federal District in Federal common matters for all the Mexican Republic.

\section{EIGHTH.- EARLY TERMINATION.}

PEP may take an early termination of this Agreement, due to MEI non compliance to the stated provisions, as well as in such a case that, it is convenient to PEP's interests. In such event, PEP shall be obliged to deliver to MEI the results of the performed tests. MEl shall not have the right to make any claims.

For such effects, PEP shall notify in written to MEl, and this latter shall immediately terminate the tests, with not prejudice that MEI previously take the precautory measures to avoid PEP to suffer from any damage.

\section{NINTH.- SURVEILLANCE OF THE SERVICES}

PEP through a designated representative shall be able to control, verify and check out that the services are being rendered in accordance to what has been agreed. 
MEI is obliged to grant all easiness to PEP in order to execute this faculties, in the intelligence that the compliance or non compliance of this faculty releases MEI from the obligations and responsibilities acquired in under this Agreement.

\section{TENTH.- ASSIGNMENT OF RIGHTS AND OBLIGATIONS}

MEI shall not assign the rights and obligations derived from this Agreement in whole or partially, to any other individual or company.

\section{ELEVENTH.- FORCE MAJEURE}

For all legal purposes of this Agreement, the non compliance of obligations due to unforeseen circumstances of force majeure, shall consist a release of liability for the obliged part, from any responsibility. When due to force majeure, it is impossible to keep on with the performance of the test, PEP or MEl shall stop the rendering for the time

GRATUTTOUS TITLE AGREEMENT

NUMBER:

MAURER ENGINEERING INC.

considered as necessary, or terminate the test, prior a written notification given to the other party.

Force majeure shall be understood as those conditions or events that are beyond the control of either of the parties, such as strikes and labor disturbances (provided that no cause has been given and no contribution has been made to the said strikes or labor disturbances).

Likewise, mutinies, quarantines, epidemics, wars (whether declared or undeclared), blockades, civil unrest, insurrection, fires (provided that no cause has been given and no contribution has been made to the said events), storms or any other cause which, by being beyond the control of the parties, prevents the fulfillment of any obligation.

\section{TWELFTH.- INFORMATION CONFIDENTIALITY AND OWNERSHIP}

The parties are obliged to maintain a strict confidentiality related to the information and data mutually provided, in reference to the test object 
of this Agreement. Therefore, this information cannot be used for any purpose different than the ones stipulated in this instrument.

MEI shall have the right to publish or inform the results derived from this test, to the United States Department of Energy.

In case of a violation to this clause, the law-breaker party, will be responsible for the damages and prejudices caused to the other party.

\section{THIRTEENTH.- LICENSES AND PATENTS}

MEl shall be the sole responsible party for the misuse of patents, licenses, rights and priorities pertaining to third parties. Any charge for this concept shall exclusively be under MEI expenses, and this shall release PEP from any responsibility, being in charge of claims if existing, and indemnify PEP for any amount which may be paid for this concept.

\section{FOURTEENTH.- COMPETENCE}

For the interpretation and compliance of this Agreement, as well as for all that which is not expressly stated in this document, the parties are subjected to the jurisdiction and the competence of Mexican Laws and Federal Courts located at the City of Villahermosa, Tabasco. Therefore,

GRATUITOUS TITLE AGREEMENT

NUMBER:

MLAURER ENGINEERING INC.

MEl waives to any rights which may correspond them through reasons of their present or future domicile or for any other reason.

This Agreement was read and, once the parties are aware of its content and legal scope, it is signed in three samples in the city of Villahermosa, Tabasco, the of , nineteen ninety nine.

LIC.

LEGAL REPRESENTATIVE

PEP REGION 
LIC.

ADMINISTRATION AND

FINANCING MANAGER
ING. CARLOS ISLAS SILVA TECHNOLOGY MANAGER

ON BEHALF OF

PEMEX-EXPLORACIÓN

INC.

YPRODUCCIÓN

ING. CARLOS RASSO ZAMORA

WELL DRILLING AND.

LIC. ROBERT SAUCEDO

LEGAL REPRESENTATIVE 
ANNEX "B" OF THE GRATUITOUS TITLE AGREEMENT TO DEVELOP THE TECHNOLOGICAL TEST ENTER ON ONE SIDE PEMEXEXPLORACIÓN Y PRODUCCIÓN, HEREINAFTER KNOWN AS "PEP", AND ON THE OTHER, THE ENTERPRISE MAURER ENGINEERING INC., HEREINAFTER KNOWN AS "MEI", IN ORDER TO ESTABLISH THE FOLLOWING:

\section{TECHNICAL SPECIFICATIONS}

Description and performance of MEI equipment.- MEI equipment is described as a downhole turbine for drilling works at high temperatures, it consists of a new system known as "vector oil tool", and it basically consists in a group of gears which reduce the conventional downhole engine speed, with typical speeds between 90 and $120 \mathrm{rpm}$ and torque around $7000 \mathrm{lb}$-pie, making it perfect to use with three-wings cutter heads in hard formations.

Description and purpose of the tests with MEI equipment.- MEI shall advice during the drill tubing assembly and the operation of the equipment described in Annex E-1. Further on, its behavior shall be observed during the drilling process, recording the time of execution and performance of the system in order to be assessed.

Location and conditions for the performance of the tests. The test purpose of this Agreement, shall be carried out in well number with drilling equipment No. 108, of the Northern Division located at Reynosa Tamaulipas Operative Unit.

The equipment availability is subjected to PEP operating schedule.

Term of execution.- The tests purpose of this Agreement shall be performed for a maximum period of 70 effective operating hours.

Specifications.-MEI is committed to notify PEP representative, about the existence of elements that due to its nature or location may provoke a hazardous situation to PEP's personnel, facilities, equipment and accessories, due to the tests purpose of this Agreement.

MEI equipment and tests shall be subjected to the International Safety Regulations, API and those valid for PEP which are established in their 
working centers, as well as all applicable legal provisions of the United Mexican States.

MEI personnel shall be registered before Administrative authorities of the Northern Drilling Division, Reynosa Operative Unit, with the purpose of being

ANIEX "B"

GRATUITOUS TITLE AGREEMIENT

NUMBBER:

MAURER ENGINEERING INC.

included in the Emergency Response Plans and/or Emergency evacuations. Also, they have to be aware of all specific guidelines to follow when working with PEP drilling equipment.

MEI personnel shall establish communication with PEP operative personnel of the division, in order to coordinate in a timely manner, the proper installation, operation and dismantling of MEl equipment.

Responsibilities.- The organization, execution, direction and risks of the test, object of this Agreement shall be under PEP expenses, with MEI consultancy.

Prior to the execution of the technological Test, PEP and MEI personnel shall prepare a work schedule. They shall discuss and agree all technical aspects of the technological test as well as the safety measures to take when using the Advanced Geothermal Turbine.

MEl shall be responsible for their personnel safety, releasing PEP from any liability on this matter.

Test surveillance.- PEP shall supervise the tests purpose of this Agreement and shall provide to $M E I$ the pertinent instructions regarding its execution.

PEP shall inspect and approve the facilities, materials and equipment to be used in the execution of the test. PEP surveillance does not imply the releasing MEl from any of the obligations of this Agreement.

Reports.- For evaluation purposes and acceptance of the test, MEI shall prepare a Log Book in order to control daily operations and the activities performed during this test. These activities shall also be supervised by a PEP engineer who shall send a copy to the Drilling Division. Likewise, MEI, shall elaborate and submit PEP, a summary of it, when the test has been terminated. 
Test Assessment Parameters.- The assessment shall be performed under the following corresponding criterion:

- Turbine installation time in the drill tubing.

- Drilling time outrage due to system adjustment.

- Safety and reliability when adjusting the System.

- Quality of the advisory given by MEl.

- Applicability in all types and marks of drilling equipment.

- Applicability in all conditions and drilling operations.

ANNEX "B"

GRATUTTOUS TITLE AGREEMENT

NUMDER:

MAURER ENGINEERTIG INC.

- Drilling equipment modifications.

- Time for servicing the system.

- Cost of servicing the system.

- Spare parts availability.

- Setting frequency.

- Registers of the obtained drilling speeds.

- Travel frequency for downhole engine changes.

- System maneuvers to take the piping in and out and the required time.

- Type of formations drilled.

- Temperature profile in the drilling interval.

- Tubing behavior in order to keep, increase and decrease the well angle.

- Operating conditions handled, rpm, load on the bit, torque, drag, etc.

Test Suspension.- PEP has the power of temporary suspending in whole or in part, the agreed test, by notifying MEl, in writing, the suspension of the said test.

Temporary suspention of the test : PEP has the faculty of suspended, in whole or partially, the test agreed, notifiying in a written letter to MEI.

Completion and Evaluation of the Technological Test.- When MEI notifies PEP in writing, the competition of the Technological Test, object of this Agreement, PEP shall evaluate them for such effect. MEI shall deliver to PEP a summary of the operations performed during the test, their conclusions and suggestions. PEP shall issue the results of the assessment in a 10 day term after the delivery of the summary. 
This Annex, having been read, and the parties having been aware of its contents and scope, is being executed in 3 (three) copies, in the City of Villahermosa, Tabasco, the of , 1999.

ADMINISTRATIVE REVIEW

LIC.

ADMINISTRATION AND

FINANCING MANAGER
TECHNICAL REVIEW

ING. CARLOS ISLAS SILVA

TECHNOLOGY MANAGER

ANNEX "B"

GRATUITOUS TITLE AGREEMENT

NUMBER:

MAURER ENGINEERING INC.

\section{ON BEHALF OF}

PEMEX-EXPLORACIÓN

MAURER ENGINEERING

INC.

Y PRODUCCIÓN

ING. CARLOS RASSO ZAMORA

WELL DRILLING AND

LIC. ROBERT SAUCEDO

MAINTENANCE 
ANNEX "E" OF THE GRATUITOUS TITLE AGREEMENT TO DEVELOP THE TECHNOLOGICAL TEST ENTER ON ONE SIDE PEMEXEXPLORACIÓN Y PRODUCCIÓN, HEREINAFTER KNOWN AS "PEP", AND ON THE OTHER, THE ENTERPRISE MAURER ENGINEERING INC., HEREINAFTER KNOWN AS "MEI", IN ORDER TO ESTABLISH THE FOLLOWING:

\section{EQUIPMENT WHICH SHALL BE PROVIDED BY PEP}

PEP shall transport all MEI personnel, equipment, tools, accesories and materials, from the border of Reynosa, Tamaulipas, to the site where the test shall be performed.

PEP shall provide the drilling equipment, as well as loading and unloding MEl's equipment.

PEP shall provide lodging and food to MEI personnel, only when working in offshore drilling platforms, during the execution of the tests, or whenever PEP requires it.

PEP may facilitate the installations and dismantling of MEI equipment.

This Annex " $\mathrm{E}$ " was read and the parties are aware of its contents and scope, it is signed in three (3) samples, in the City of Villahermosa, Tabasco, the. of , 1999.-

ADMINISTRATIVE REVIEW

LIC.

ADMINISTRATION AND

FINANCING MANAGER
TECHNICAL REVIEW

ING. CARLOS ISLAS SILVA TECHNOLOGY MANAGER

ON BEHALF OF

PEMEX-EXPLORACIŌN

MAURER ENGINEERING

INC.

Y PRODUCCIÓN

ING. CARLOS RASSO ZAMORA

LIC. ROBERT SAUCEDO 


\begin{abstract}
ANNEX "E-1" OF THE GRATUITOUS TITLE AGREEMENT TO DEVELOP THE TECHNOLOGICAL TEST ENTER ON ONE SIDE PEMEXEXPLORACIÓN Y PRODUCCIÓN, HEREINAFTER KNOWN AS "PEP", AND ON THE OTHER, THE ENTERPRISE MAURER ENGINEERING INC., HEREINAFTER KNOWN AS "MEI", IN ORDER TO ESTABLISH THE FOLLOWING:
\end{abstract}

\title{
EQUIPMENT WHICH SHALL BE PROVIDED BY MEI
}

System Installation. MEI shall assess PEP during the drill tubing assembly and during the operation of the downhole geothermal turbine.

\begin{tabular}{|l|l|}
\hline \multicolumn{2}{|c|}{ ADVANCED GEOTHERMAL TURBINE } \\
\hline SIZE & DESCRIPTION \\
\hline & \\
\hline & \\
\hline & \\
\hline & \\
\hline & \\
\hline
\end{tabular}

\begin{tabular}{|l|l|}
\hline \multicolumn{2}{|c|}{ ADVANCED GEOTHERMAL TURBINE } \\
\hline & DIZE \\
\hline & \\
\hline & \\
\hline & \\
\hline & \\
\hline & \\
\hline
\end{tabular}

MEl shall provide personnel, technical advisory, downhole engine with all necessary accessories to be plugged to the drill tubing, 24 (twenty four) hours a day, during the performance of a field technological test in a drilling equipment. 
MEI offers equipment, tools, spare parts, accessories and materials which guarantees the efficient operation of drilling works during the technological test.

MEI shall provide to PEP representative an operation technical plan (including safety aspects) prior the beginning of the test for the drilling equipment scheduled.

MEI shall properly pack and document all their equipment, tools, parts, accessories and materials. PEP is released from any responsibility of damages or losses during transportation, load, unload and movements. Therefore, MEI shall count with the corresponding insurance policy against damages.

ADMINISTRATIVE REVIEW

LIC.

ADMINISTRATION AND

FINANCING MANAGER
TECHNICAL REVIEW

ING. CARLOS ISLAS SILVA

TECHNOLOGY MANAGER

\section{ON BEHALF OF}

PEMEX-EXPLORACIÓN

MAURER ENGINEERING

INC.

Y PRODUCCIÓN

ING. CARLOS RASSO ZAMORA

LIC. ROBERT SAUCEDO

WELL DRILLING AND

LEGAL REPRESENTATIVE 


\section{APPENDIX B}

Field Data 


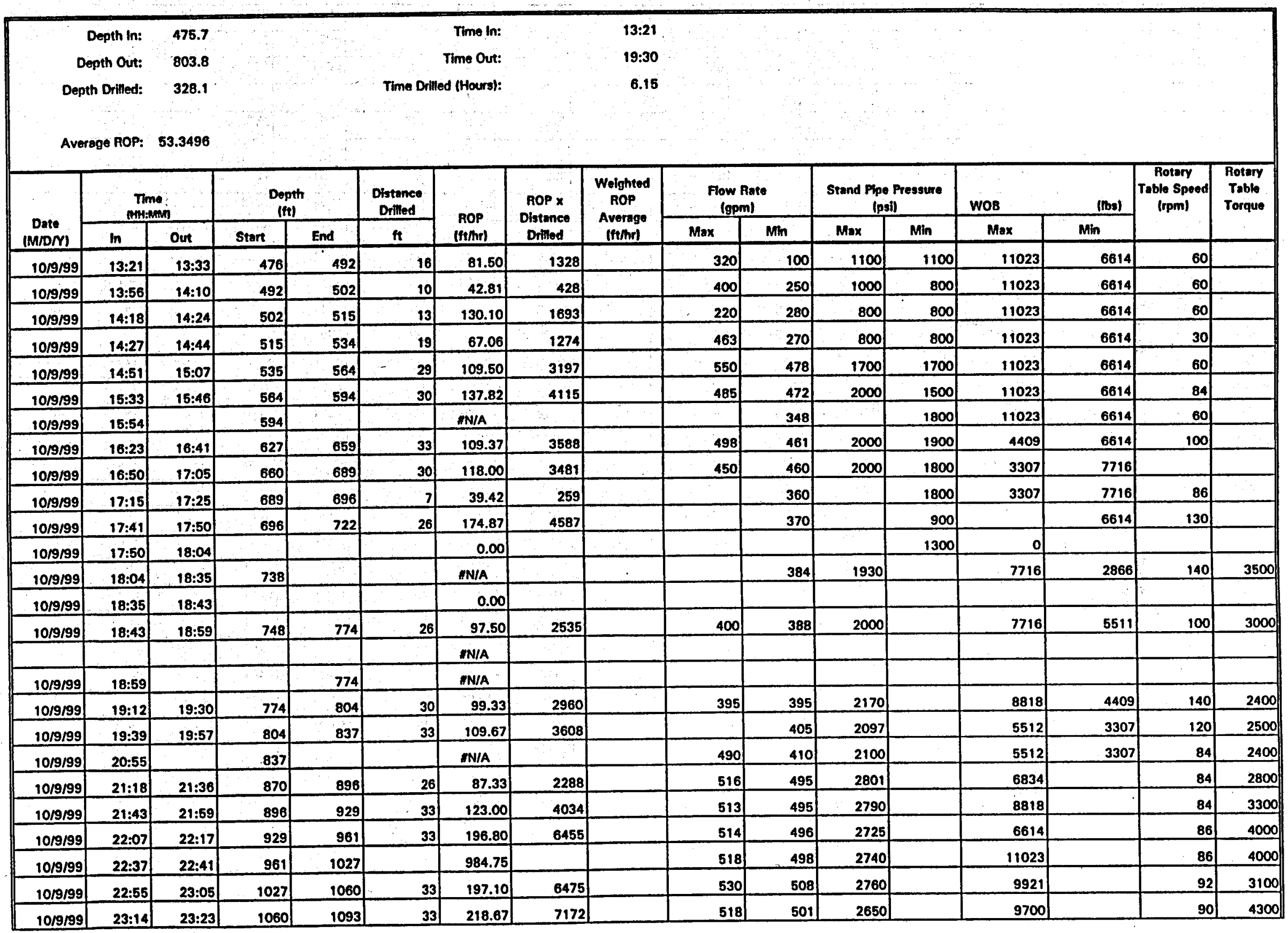




\begin{tabular}{|c|c|c|c|c|c|c|c|c|c|c|c|c|c|c|c|c|}
\hline \multirow{2}{*}{$\begin{array}{c}\text { Date } \\
\text { (M/O/Y) }\end{array}$} & \multicolumn{2}{|c|}{$\begin{array}{c}\text { Time } \\
\text { (HAH:MMB) }\end{array}$} & \multicolumn{2}{|c|}{$\begin{array}{l}\text { Depth } \\
\text { (It) }\end{array}$} & \multirow{2}{*}{$\begin{array}{c}\begin{array}{c}\text { Distance } \\
\text { Drilled }\end{array} \\
\mathbf{f t} \\
\end{array}$} & \multirow{2}{*}{$\begin{array}{c}\text { ROP } \\
\text { (fi/hn) }\end{array}$} & \multirow{2}{*}{$\begin{array}{c}\text { ROP X } \\
\text { Distance } \\
\text { Dritiod }\end{array}$} & \multirow{2}{*}{$\begin{array}{l}\text { Welghted } \\
\text { ROP } \\
\text { Average } \\
\text { (It/hr) }\end{array}$} & \multicolumn{2}{|c|}{$\begin{array}{c}\text { Flow Rate } \\
\text { (gpm) }\end{array}$} & \multicolumn{2}{|c|}{$\begin{array}{c}\text { Stand Pipe Pressure } \\
\text { (psi) } \\
\end{array}$} & \multirow{2}{*}{$\frac{\text { WOB }}{\text { Max }}$} & \multirow{2}{*}{ Min } & \multirow[t]{2}{*}{\begin{tabular}{|c|} 
Aotary \\
Table Speed \\
(rpm)
\end{tabular}} & \multirow[t]{2}{*}{$\begin{array}{l}\text { Rotary } \\
\text { Table } \\
\text { Torque }\end{array}$} \\
\hline & In & Out & Start & End & & & & & $\operatorname{Max}$ & $\mathrm{Min}$ & $\operatorname{Max}$ & Min & & & & \\
\hline 10/9/99 & 23:34 & 23:45 & 1093 & 1125 & 33 & 178.91 & 5868 & & 519 & 514 & 3050 & & 11243 & & 90 & 4800 \\
\hline 10/9/99 & 23:67 & $0: 15$ & 1125 & 1158 & 33 & 110.00 & 3608 & & 510 & 490 & 3550 & & 8818 & & 94 & 4400 \\
\hline $10 / 10 / 99$ & $0: 27$ & $0: 39$ & 1158 & 1191 & 33 & 164.00 & 5379 & & 483 & 474 & 3250 & & 14991 & & 76 & 5500 \\
\hline 10/10/99 & $0: 48$ & $0: 56$ & 1191 & 1224 & 33 & 246.00 & 8069 & & 511 & 502 & 3300 & & 16094 & & 104 & 5800 \\
\hline $10 / 10 / 99$ & $1: 03$ & $1: 13$ & 1224 & 1257 & 33 & 196.80 & 6455 & & 515 & 500 & 3400 & & 16314 & & 130 & 6000 \\
\hline \multirow[t]{2}{*}{$10 / 10 / 99$} & 1:30 & 1:46 & 1257 & 1289 & 32 & 121.50 & 3937 & & 512 & 504 & 3480 & & 17637 & & 110 & 6000 \\
\hline & & & & & & IN/A & 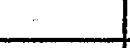 & & & & & & & & & \\
\hline $10 / 10 / 99$ & $2: 52$ & $3: 10$ & 1309 & 1342 & 33 & 109.67 & 3608 & & 516 & 492 & 2800 & & 17637 & 13228 & BO & 4800 \\
\hline $10 / 10 / 99$ & $3: 18$ & $3: 37$ & 1342 & 1375 & 33 & 103.58 & 3397 & & 517 & 504 & 2800 & & 15432 & & 96 & 5000 \\
\hline $10 / 10 / 99$ & $3: 44$ & 4:07 & 1375 & 1408 & 33 & 85.57 & 2807 & & 520 & 505 & 2800 & & 15432 & & 80 & 4100 \\
\hline $10 / 10 / 99$ & 4:15 & 4:35 & 1408 & 1440 & 33 & 97.50 & 3169 & & 520 & 505 & 2800 & & 15432 & & 80 & 5000 \\
\hline $10 / 10 / 99$ & $4: 44$ & $5: 02$ & 1440 & 1473 & 33 & 110.67 & 3674 & & 520 & 507 & 2700 & & 15432 & & 80 & 4500 \\
\hline $10 / 10 / 99$ & $5: 22$ & $5: 41$ & 1473 & 1505 & 32 & 101.05 & 3234 & & 529 & 512 & 2800 & & 14432 & & 80 & 4800 \\
\hline $10 / 10 / 99$ & 5:47 & 6:07 & 1505 & 1538 & 33 & 99.00 & 3267 & & 530 & 507 & 2800 & & 15432 & 11023 & 85 & 4500 \\
\hline 10/10/99 & $6: 15$ & $6: 33$ & 1538 & 1571 & 33 & 110.00 & 3630 & & 530 & 512 & 2800 & & 13228 & 11023 & 80 & 4500 \\
\hline 10/10/99 & 6:50 & 7:07 & 1571 & 1604 & 33 & 116.47 & 3844 & & 520 & 505 & 2800 & & 15432 & & 88 & 5300 \\
\hline $10 / 10 / 99$ & 7:13 & $7: 27$ & 1604 & 1634 & 30 & 128.57 & 3857 & & 530 & 519 & 2850 & & 15432 & & 120 & 6000 \\
\hline $10 / 10 / 99$ & $7: 36$ & $7: 51$ & 1634 & 1666 & 32 & 128.00 & 4096 & & 521 & 504 & 2600 & & 13227.6 & 11023 & 112 & 4800 \\
\hline $10 / 10 / 99$ & $8: 05$ & $8: 22$ & 1670 & 1702 & 32 & 112.94 & 3614 & & 528 & 512 & 2650 & & 14330 & & 112 & 4600 \\
\hline $10 / 10 / 99$ & 8:33 & $8: 50$ & 1702 & 1734 & 32 & 112.94 & 3614 & & 532 & 517 & 2700 & & 13889 & & 112 & 4400 \\
\hline $10 / 10 / 99$ & 9:00 & 9:13 & 1734 & 1766 & 32 & 147.69 & 4726 & & 556 & 537 & 2850 & & 15432 & 13228 & 120 & 4350 \\
\hline $10 / 10 / 99$ & 9:30 & $10: 08$ & 1766 & 1799 & 33 & 52.11 & 1719 & & 535 & 518 & 2800 & & 15432 & & 40 & 3400 \\
\hline $10 / 10 / 99$ & $10: 17$ & $10: 30$ & 1799 & 1831 & 32 & 147.69 & 4726 & HuHEHAFAH & 550 & 533 & 2800 & & 13228 & 11023 & 120 & 4400 \\
\hline $10 / 10 / 99$ & $10: 43$ & 11:10 & 1831 & 1851 & 20 & 44.44 & 889 & & 550 & 540 & 2800 & & 8818 & 6614 & 120 & 4000 \\
\hline . & & & & & & NN/A & & & & & : & & & & & \\
\hline $10 / 10 / 99$ & $11: 23$ & & 1827 & 1855 & 28 & NN/A & & & 520 & 515 & 2800 & & 15432 & & 48 & 2800 \\
\hline 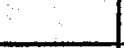 & & & & & & IN/A & & & & & & & & & & \\
\hline 10/10/99 & $11: 23$ & $11: 37$ & 1827 & 1835 & 8 & 34.29 & 274 & & 520 & 515 & 2800 & & 15432 & & 48 & 2650 \\
\hline 10/10/99 & $11: 37$ & $11: 42$ & 1835 & 1838 & 3 & 36.00 & 108 & & 492 & 490 & 2700 & & 4409 & & 92 & 3000 \\
\hline $10 / 10 / 99$ & $11: 42$ & $11: 45$ & 1838 & 1841 & 3 & 51.43 & 154 & & 492 & 490 & 2700 & & 4409 & & 92 & 2600 \\
\hline & & & & & & NN/A & & & & & & & & & & \\
\hline $10 / 10 / 99$ & $11: 23$ & $12: 07$ & 1827 & 1850 & 23 & 31.36 & 721 & & 520 & 515 & 2800 & & 9921 & & 48 & 2700 \\
\hline
\end{tabular}




\begin{tabular}{|c|c|c|c|c|c|c|c|c|c|c|c|c|c|c|c|c|}
\hline \multirow{2}{*}{$\begin{array}{l}\text { Date } \\
\text { (MMOM) }\end{array}$} & \multicolumn{2}{|c|}{ Time } & \multicolumn{2}{|c|}{$\begin{array}{c}\text { Depth } \\
\text { (ft) }\end{array}$} & \multirow{2}{*}{$\begin{array}{c}\begin{array}{c}\text { Distance } \\
\text { Ditiled }\end{array} \\
\mathbf{f t} \\
\end{array}$} & \multirow{2}{*}{$\begin{array}{c}\text { nOP } \\
\text { (ftent) }\end{array}$} & \multirow{2}{*}{$\begin{array}{l}\text { ROP X } \\
\text { Distance } \\
\text { Ditliod } \\
\end{array}$} & \multirow{2}{*}{$\begin{array}{c}\text { Weighted } \\
\text { nop } \\
\text { Average } \\
\text { (frmm) }\end{array}$} & \multicolumn{2}{|c|}{$\begin{array}{c}\text { Flow Rate } \\
\text { (gpm) }\end{array}$} & \multicolumn{2}{|c|}{$\begin{array}{c}\text { Stand Pipe Pressure } \\
\text { (psi) }\end{array}$} & \multirow{2}{*}{$\frac{W O B}{\operatorname{Max}}$} & \multirow{2}{*}{$\frac{\text { (tbs) }}{\operatorname{Min}}$} & \multirow[t]{2}{*}{$\begin{array}{c}\text { Aotary } \\
\text { Table Speed } \\
\text { (rpm) }\end{array}$} & \multirow[t]{2}{*}{$\begin{array}{c}\text { Rotary } \\
\text { Tablo } \\
\text { Torque }\end{array}$} \\
\hline & In & out & Start & End & & & & & $\operatorname{Max}$ & $\mathrm{Mm}$ & Max & $\mathrm{Min}$ & & & & \\
\hline $10 / 10 / 99$ & 12:15 & $12: 55$ & 1850 & 1889 & 39 & 58.50 & 2282 & & 486 & 496 & 2400 & 2850 & 6614 & & 100 & 3200 \\
\hline $10 / 10 / 99$ & 13:03 & 13:32 & 1890 & 1919 & 30 & 61.12 & 1805 & & 501 & & 2350 & & 6614 & & $8 B$ & \\
\hline $10 / 10 / 99$ & $13: 55$ & $14: 25$ & 1919 & 1952 & 33 & 65.62 & 2153 & & 530 & & 2800 & & 11023 & 8818 & 80 & \\
\hline 10/10/99 & 14:45 & 15:26 & 1952 & 1982 & 30 & 43.19 & 1274 & & 550 & & 2850 & & 11023 & & 100 & 3500 \\
\hline $10 / 10 / 99$ & $15: 32$ & 16:07 & 1982 & 2015 & 33 & 56.23 & 1844 & & 550 & & 2850 & & 17637 & 17636 & 110 & 4400 \\
\hline $10 / 10 / 99$ & $16: 15$ & $17: 03$ & 2015 & 2047 & 33 & 40.63 & 1320 & & 554 & 540 & 2850 & & 19841 & - & 100 & 4500 \\
\hline $10 / 10 / 99$ & $17: 18$ & $17: 58$ & 2047 & 2077 & 30 & 44.80 & 1338 & & 552 & 547 & 2800 & & 13228 & & 100 & 4200 \\
\hline 10/10/99 & $18: 08$ & 19:07 & 2077 & 2143 & 66 & 66.74 & 4380 & & 558 & 545 & 2783 & 2750 & 13228 & 11023 & 94 & 3850 \\
\hline 10/10/99 & $18: 17$ & 19:54 & 2110 & 2143 & 33 & 20.30 & 666 & & 558 & 545 & 2783 & 2750 & 13228 & 11023 & $\ldots$ & 3950 \\
\hline- & $\ldots$ & $\therefore \quad$ & & & 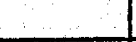 & IN/A & & & & & & & & & $\ldots$ & \\
\hline $10 / 10 / 99$ & 20:04 & 20:33 & 2143 & 2169 & 26 & 54.21 & 1420 & & 560 & 547 & 2802 & 2750 & 14109 & & 98 & 4640 \\
\hline & $\therefore$ & & $\cdots$ & $\ldots$ & 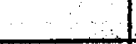 & IN/A & $n-$ & & 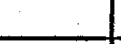 &. & & & & & & \\
\hline 10/10/9g & $21: 58$ & $22: 28$ & 2234 & 2261 & 27 & 53.20 & 1415 & & 582 & 521 & 2758 & & 19841 & 15432 & 88 & 4700 \\
\hline $10 / 10 / 99$ & 22:37 & 23:06 & 2261 & 2297 & 36 & 74.69 & 2696 & & 576 & 560 & 2950 & & 15432 & & 84 & 3950 \\
\hline $10 / 10 / 99$ & 23:20 & $23: 45$ & 2297 & 2326 & 29 & 70.32 & 2060 & & 570 & 563 & 2900 & & 15432 & & 80 & 4800 \\
\hline 10/10/99 & 23:55 & $0: 43$ & 2326 & 2356 & 30 & 37.20 & 1107 & & 580 & 555 & 2800 & 2700 & 24251 & 15873 & 85 & 4000 \\
\hline 10/11/99 & $0: 52$ & $1: 52$ & 2356 & 2389 & 33 & 32.80 & 1076 & & 540 & 525 & 2600 & 2500 & 24251 & 17196 & 100 & 2800 \\
\hline $10 / 11 / 99$ & $2: 02$ & 2:25 & 2389 & 2418 & 30 & 77.03 & 2275 & & 518 & 506 & 2454 & 2400 & 19841 & 13228 & 100 & 4320 \\
\hline $10 / 11 / 99$ & $2: 47$ & $3: 15$ & 2418 & 2451 & 33 & 70.31 & 2307 & & 528 & 512 & 2542 & 2500 & 15432 & 11023 & 80 & 4500 \\
\hline $10 / 11 / 99$ & 3:23 & $4: 00$ & 2451 & 2484 & 33 & 53.19 & 1745 & & 540 & 525 & 2663 & 2550 & 15432 & & 80 & 4200 \\
\hline $10 / 11 / 99$ & 4:09 & $4: 47$ & 2484 & 2513 & 29 & 46.26 & $\therefore \quad 1356$ & & 594 & 532 & 2776 & 2700 & 17637 & & 88 & 3800 \\
\hline $10 / 11 / 99$ & $4: 55$ & $5: 33$ & 2513 & 2546 & 33 & 52.26 & $\cdots \cdots 1730$ & & 540 & 536 & 2600 & & 17637 & & 88 & 5296 \\
\hline 10/11/99 & $5: 44$ & $6: 25$ & 2546 & 2579 & 33 & 47.96 & 1572 & & 545 & & 2600 & & 19841 & 17637 & 82 & 4150 \\
\hline 10/11/99 & $6: 40$ & $7: 16$ & 2579 & 2608 & 29 & 48.55 & $\quad 1414$ & & 547 & 533 & 2693 & 2500 & 17637 & & 88 & 4200 \\
\hline $10 / 11 / 99$ & 7:31 & $8: 06$ & 2608 & 2638 & 30 & 51.26 & 1533 & & 545 & 530 & 2766 & 2700 & 22046 & 15432 & 80 & 5000 \\
\hline \multirow[t]{4}{*}{$10 / 11 / 99$} & 8:15 & & 2638 & & & NN/A & & & 525 & 508 & & 2520 & 2500 & 17637 & 80 & 5600 \\
\hline & & & & 2671 & & IN/A & & & & & & & & & & \\
\hline & & & & 2704 & & NN/A & & & & & & & & & & \\
\hline & & & & & & IN/A & & & & & & & & & & \\
\hline $10 / 11 / 99$ & & & & 2736 & & NN/A & & & & & & & & & & \\
\hline $10 / 11 / 99$ & & & & 2766 & & MN/A & & & & & & & & & & \\
\hline $10 / 11 / 99$ & & $12: 00$ & & 2799 & & N/A & & & & & & & & & & \\
\hline
\end{tabular}




\begin{tabular}{|c|c|c|c|c|c|c|c|c|c|c|c|c|c|c|c|c|}
\hline \multirow{2}{*}{$\begin{array}{c}\text { Date } \\
\text { (M/O/Y) }\end{array}$} & \multicolumn{2}{|c|}{$\begin{array}{c}\text { Time } \\
\text { (HH:MMMI } \\
\end{array}$} & \multicolumn{2}{|c|}{$\begin{array}{c}\text { Depth } \\
\text { (if) }\end{array}$} & \multirow{2}{*}{$\begin{array}{c}\begin{array}{c}\text { Distance } \\
\text { Drilled }\end{array} \\
\mathrm{ft}\end{array}$} & \multirow{2}{*}{$\begin{array}{c}\text { ROP } \\
\text { (ft/mr) }\end{array}$} & \multirow{2}{*}{$\begin{array}{c}\text { ROP x } \\
\text { Distance } \\
\text { Drilled }\end{array}$} & \multirow{2}{*}{$\begin{array}{c}\text { Weighted } \\
\text { ROP } \\
\text { Average } \\
\text { (ft/hr) } \\
\end{array}$} & \multicolumn{2}{|c|}{$\begin{array}{c}\text { Flow Rate } \\
\text { (gpm) }\end{array}$} & \multicolumn{2}{|c|}{$\begin{array}{c}\text { Stand Pipe Pressure } \\
\text { (psi) }\end{array}$} & \multirow{2}{*}{$\frac{\text { WOB }}{\text { Max }}$} & \multirow{2}{*}{ (Ibs) } & \multirow[t]{2}{*}{\begin{tabular}{c|} 
Rotary \\
Table Speed \\
(rpm)
\end{tabular}} & \multirow[t]{2}{*}{$\begin{array}{l}\text { Rotary } \\
\text { Table } \\
\text { Torquue }\end{array}$} \\
\hline & In & Out & Start & End & & & & & $\operatorname{Max}$ & $\mathrm{Min}$ & $\operatorname{Max}$ & $\operatorname{Min}$ & & & & \\
\hline $10 / 11 / 99$ & 12:05 & $12: 42$ & 2799 & 2828 & 29 & 47.53 & 1393 & & 528 & 514 & 2665 & 2500 & 22046 & & 84 & 4200 \\
\hline \multirow[t]{2}{*}{$10 / 11 / 99$} & $13: 32$ & & 2828 & & & IN/A & & & 559 & & 2820 & 2750 & 19414 & & 92 & 5100 \\
\hline & & & & & & \#N/A & & & & & & & & & & \\
\hline \multirow[t]{2}{*}{$10 / 11 / 99$} & $16: 39$ & & 2887 & & & IN/A & & & 557 & & 2770 & 2700 & 19841 & & 70 & \\
\hline & & & & & & IN/A & & & & & & & & & & \\
\hline $10 / 11 / 99$ & 20:12 & $20: 34$ & 2976 & 2989 & 13 & 35.78 & 469 & & 561 & & 2760 & 2650 & 17637 & 13228 & 82 & 4480 \\
\hline $10 / 11 / 99$ & $20: 41$ & 22:03 & 2989 & 3022 & 33 & 24.01 & 788 & & 600 & 570 & 2860 & 2800 & 15432 & & 100 & 3990 \\
\hline $10 / 11 / 99$ & 22:11 & 22:47 & 3022 & 3045 & 23 & 38.27 & 879 & & 618 & & 3301 & 3000 & 15211 & & 92 & 4800 \\
\hline $10 / 11 / 99$ & $22: 54$ & 23:36 & 3045 & 3074 & 29 & 41.77 & 1221 & & 612 & & 3280 & 3050 & 16755 & & 92 & 4300 \\
\hline $10 / 12 / 99$ & 23:51 & $0: 25$ & 3074 & 3104 & 30 & 52.06 & 1536 & & 624 & & 3200 & 3000 & 16534 & : & 94 & 4700 \\
\hline $10 / 12 / 99$ & $1: 32$ & $2: 22$ & 3104 & 3137 & 33 & 39.36 & 1291 & & 595 & & 2950 & 2800 & 16535 & & 98 & 4200 \\
\hline $10 / 12 / 99$ & 2:34 & & 3137 & & & N/A & & & 587 & & 3000 & 3220 & 17637 & & 100 & 4100 \\
\hline 10/12/99 & & 4:08 & 3160 & 3169 & 9 & MN/A & & & 610 & & 3114 & 2950 & 19841 & 17637 & 108 & 3700 \\
\hline $10 / 12 / 99$ & 4:13 & 5:39 & 3169 & 3199 & 30 & 20.92 & 627 & & 596 & & 3114 & 2950 & 15432 & & 92 & 3600 \\
\hline $10 / 12 / 99$ & 5:50 & $7: 54$ & 3199 & 3232 & 33 & 15.88 & 521 & & 594 & & 3078 & 2900 & 15432 & 22046 & 84 & 3400 \\
\hline $10 / 12 / 99$ & $8: 05$ & 9:10 & 3232 & 3261 & 29 & 26.96 & 788 & & 608 & & 3257 & 2800 & 15432 & 17637 & 78 & 4300 \\
\hline $10 / 12 / 99$ & $9: 20$ & 9:53 & 3261 & 3291 & 30 & 54.18 & 1615 & & 698 & & 3150 & 2450 & 13228 & 15432 & 84 & 4250 \\
\hline $10 / 12 / 99$ & $10: 05$ & $10: 50$ & 3291 & 3324 & 33 & 43.80 & 1439 & & 598 & & 3100 & 2950 & 13228 & 15432 & 96 & 5000 \\
\hline \multirow[t]{2}{*}{$10 / 12 / 99$} & $11: 00$ & $11: 21$ & 3324 & 3353 & 29 & 83.86 & 2461 & & 612 & & 3377 & 3150 & 19841 & & 88 & 5750 \\
\hline & & & & & & IN/A & & & & & & & & & & \\
\hline $10 / 12 / 99$ & $18: 40$ & 19:39 & 3478 & 3511 & 33 & 33.37 & 1095 & & 575 & & 3148 & 3000 & 19841 & & 88 & 4700 \\
\hline $10 / 12199$ & 19:48 & $20: 42$ & 3511 & 3544 & 33 & 36.48 & 1198 & & 580 & & 3200 & 3000 & 19841 & & 100 & 4800 \\
\hline $10 / 12 / 99$ & $20: 50$ & 21:26 & 3544 & 3570 & 26 & 43.67 & 1144 & & 616 & & 3350 & 3100 & 15432 & & 112 & 4900 \\
\hline $10 / 12 / 99$ & $21: 36$ & 22:18 & 3570 & 3603 & 33 & 46.86 & 1537 & & 610 & & 3350 & 3100 & 17637 & & 70 & 4600 \\
\hline $10 / 12 / 99$ & 22:27 & $22: 58$ & 3603 & 3632 & 30 & 57.29 & 1696 & & 615 & & 3370 & 3100 & 15432 & & 70 & 4800 \\
\hline $10 / 12 / 99$ & $23: 07$ & 23:59 & 3632 & 3665 & 33 & 37.82 & 1240 & & 620 & & 3368 & 3200 & 17637 & & 79 & 4800 \\
\hline $10 / 13 / 99$ & $0: 10$ & $1: 09$ & 3665 & 3698 & 33 & 33.37 & 1095 & & 626 & & 3400 & 3200 & 19841 & & 58 & 5200 \\
\hline 10/13/99 & 1:21 & $2: 14$ & 3698 & 3727 & 30 & 33.41 & 986 & & 600 & & 3150 & 3000 & 13228 & & 79 & 3860 \\
\hline $10 / 13 / 99$ & $2: 24$ & $3: 24$ & 3727 & 3757 & 30 & 29.70 & 882 & & 609 & & 3240 & 3000 & 15432 & & 90 & 4000 \\
\hline 10/13/99 & $3: 38$ & $4: 31$ & 3757 & 3790 & 33 & 37.20 & 1222 & & 620 & & 3313 & 3150 & 17637 & 13228 & 80 & 4500 \\
\hline \multirow[t]{2}{*}{ 10/13/99 } & 4:48 & & 3790 & & & INIA & & & 615 & & 3150 & & & & 76 & \\
\hline & & & & & & \#N/A & & & & & & & & & & \\
\hline
\end{tabular}




\begin{tabular}{|c|c|c|c|c|c|c|c|c|c|c|c|c|c|c|c|c|}
\hline \multirow{2}{*}{$\begin{array}{l}\text { Date } \\
\text { (M/DM) }\end{array}$} & \multicolumn{2}{|c|}{$\begin{array}{c}\text { Time } \\
\text { nnmis:minn }\end{array}$} & \multicolumn{2}{|c|}{$\begin{array}{c}\text { Depth } \\
\text { (ff] }\end{array}$} & \multirow{2}{*}{$\begin{array}{c}\begin{array}{c}\text { Distenee } \\
\text { Dimitied }\end{array} \\
\mathrm{ft} \\
\end{array}$} & \multirow{2}{*}{$\begin{array}{l}\text { ROP } \\
\text { (trmer) } \\
\end{array}$} & \multirow{2}{*}{$\begin{array}{c}\text { ROP X } \\
\text { Distance } \\
\text { Oritied }\end{array}$} & \multirow{2}{*}{$\begin{array}{c}\text { Weighted } \\
\text { ROP } \\
\text { Avergage } \\
\text { (tffur) } \\
\end{array}$} & \multicolumn{2}{|c|}{$\begin{array}{c}\text { Flow Rate } \\
\text { (gpm) }\end{array}$} & \multicolumn{2}{|c|}{$\begin{array}{c}\text { Siand Plpe Pressure } \\
\text { (psi) }\end{array}$} & \multirow{2}{*}{$\frac{\text { WOB }}{\text { Max }}$} & \multirow{2}{*}{ (lbs) } & \multirow[t]{2}{*}{$\begin{array}{c}\text { Rotary } \\
\text { Table Speed } \\
\text { (rpm) }\end{array}$} & \multirow[t]{2}{*}{$\begin{array}{l}\text { Rotary } \\
\text { Table } \\
\text { Torque }\end{array}$} \\
\hline & in & Out & Start & End & & & & & $\max$ & Min & $\operatorname{Max}$ & $\mathrm{Mm}$ & & & & \\
\hline $10 / 13 / 99$ & $4: 48$ & 5:34 & 3790 & 3822 & 33 & 42.83 & 1407 & & 618 & 618 & 3150 & & 14550.4 & 10582 & 76 & 4500 \\
\hline 10/13/99 & 6:07 & 7:30 & 3822 & 3859 & 36 & 26.10 & 942 & 45 & 604 & 603 & 3100 & & 26455 & 11023 & 69 & 4000 \\
\hline \multirow[t]{2}{*}{$10 / 13 / 99$} & $7: 43$ & & 3859 & & & IN/A & & & 607 & & 3450 & 3050 & 26455 & 19841 & 92 & 3400 \\
\hline & & & & & & IN/A & & & & & & & & & & \\
\hline $\mathrm{POOH}$ & & & & & & IN/A & & & & & & & & & & \\
\hline
\end{tabular}

